UNIVERSIDADE ESTADUAL PAULISTA “JÚLIO DE MESQUITA FILHO” FACULDADE DE CIÊNCIAS AGRONÔMICAS CAMPUS DE BOTUCATU

\title{
CARACTERIZAÇÃO DE PRODUTOS EXTRUSADOS DE MISTURAS DE FARINHA DE SOJA, FÉCULA E FARELO DE MANDIOCA
}

FERNANDA ROSSI MORETTI TROMBINI

Dissertação apresentada à Faculdade de Ciências Agronômicas da UNESP - Campus de Botucatu, para obtenção do título de Mestre em Agronomia (Energia na Agricultura).

BOTUCATU - SP

Março - 2010 
UNIVERSIDADE ESTADUAL PAULISTA “JÚLIO DE MESQUITA FILHO” FACULDADE DE CIÊNCIAS AGRONÔMICAS CAMPUS DE BOTUCATU

\section{CARACTERIZAÇÃO DE PRODUTOS EXTRUSADOS DE MISTURAS DE FARINHA DE SOJA, FÉCULA E FARELO DE MANDIOCA}

\section{FERNANDA ROSSI MORETTI TROMBINI}

Orientadora: Profa. Dra. Magali Leonel

Dissertação apresentada à Faculdade de Ciências Agronômicas da UNESP - Campus de Botucatu, para obtenção do título de Mestre em Agronomia (Energia na Agricultura).

BOTUCATU - SP

Março - 2010 
FICHA CATALOGRÁFICA ELABORADA PELA SEÇÃo TÉCNICA DE AQUISIÇÃO E TRATAMENTO DA INFORMAÇÃO - SERVIÇO TÉCNICO DE BIBLIOTECA E DOCUMENTAÇÃO UNESP - FCA LAGEADO - BOTUCATU (SP)

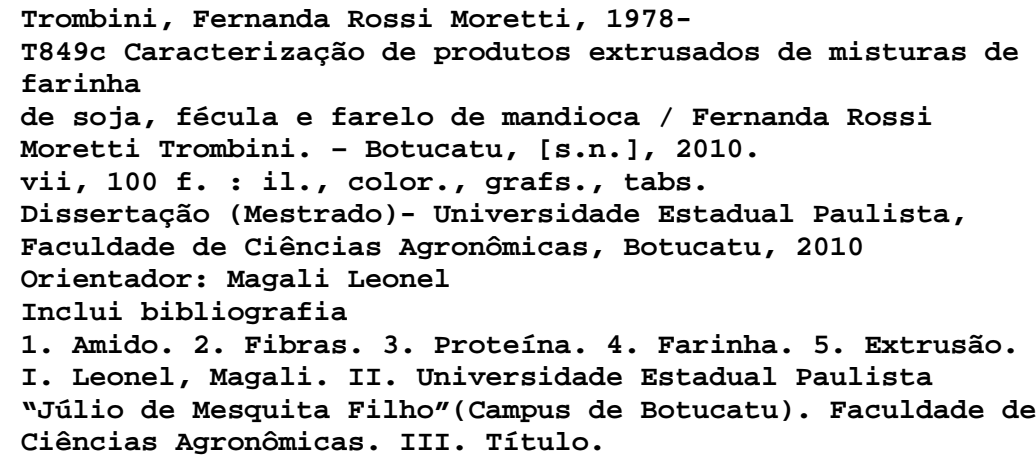




\section{UNIVERSIDADE ESTADUAL PAULISTA "JÚLO DE MFSQUTTA FLLHO" FACULDADE DE CIÊNCIAS AGRONÔMICAS CAMPUS DE BOTUCATU \\ CERTIFICADO DE APROVAÇ̃o}

TITULO: "CARACTERTZACT̃O DE PRCOUTOS EXTRLSADOG DE MISTURAS LE: FARINHA DE SOIA. PBCUIA E PAREIO DE MANDIOCA"

ALUNA: FERNANDA ROSSI MORETTI TROMBINI ORIENTADOR: PROFA. DRA. MAGALI LEONEL

Aprovado pela Comissão Examinadora
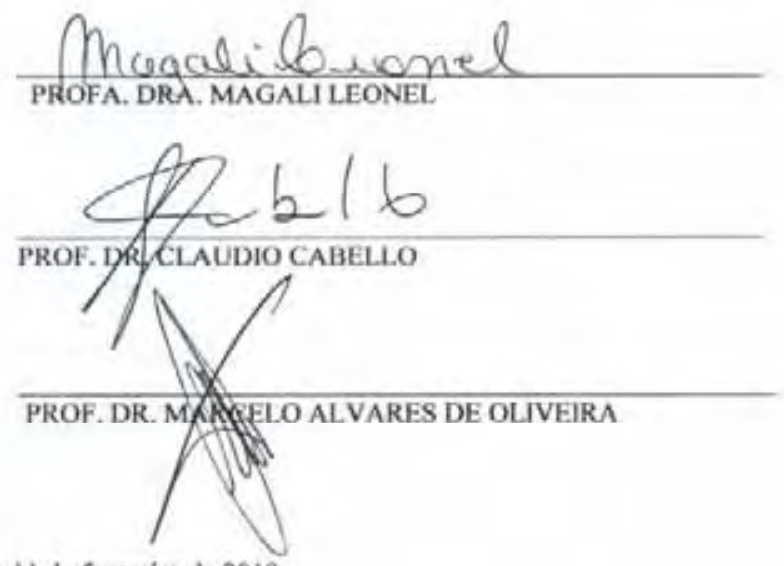

Data da Realização: 11 de fevereiro de 2010. 


\section{AGRADECIMENTOS}

À Deus, que me conduziu durante esse curso nos momentos de dificuldades e permitiu que esse trabalho fosse realizado.

À minha família e meu esposo pelo amor, compreensão, paciência e em todos os momentos da minha vida.

À minha orientadora Magali Leonel, que participou ativamente no desenvolvimento desse trabalho, sempre me apoiando e orientando da melhor forma para que, não só, fosse realizado a obtenção desse título, mas também, o meu crescimento profissional.

À Profa. Martha Maria Mischan pela análise estatística dos dados.

À banca examinadora, pela contribuição nesse projeto.

Aos técnicos do Laboratório de Análise do CERAT, Luiz Henrique e Priscila, os quais me deram suporte técnico no decorrer desse trabalho.

Ao técnico do Laboratório de Processos do CERAT, Douglas, pela contribuição na produção dos extrusados.

À secretária do CERAT, Alessandra, por sua atenção.

Aos funcionários da biblioteca da FCA, pelo auxílio, atenção e amizade, durante a elaboração desse trabalho.

Aos amigos do CERAT, pelos momentos descontraídos e aqueles que de certa forma tiveram passagem no decorrer do curso. 


\section{SUMÁRIO}

Página

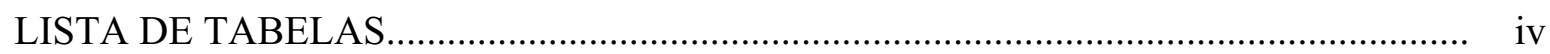

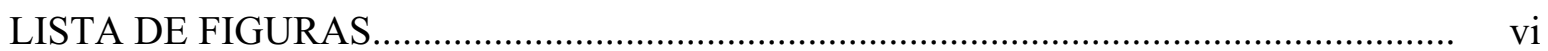

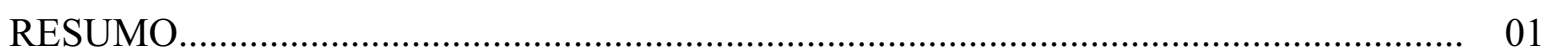

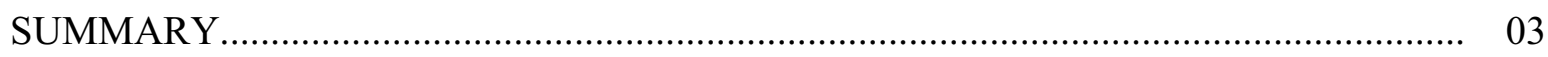

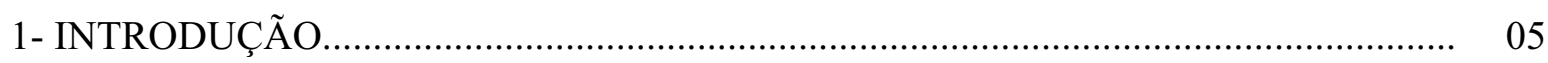

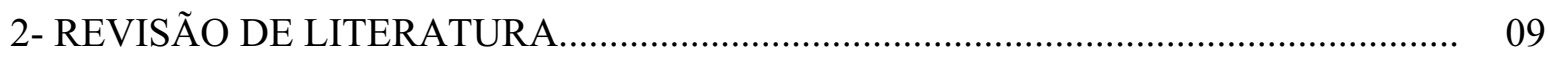

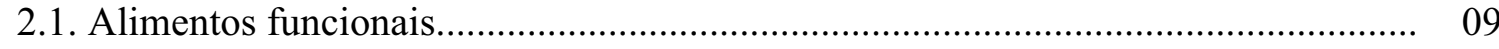

2.2. Processo de extrusão....................................................................................... 11

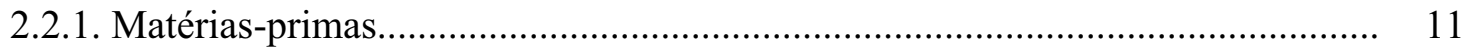

2.2.1.1. Fécula de mandioca.................................................................................... 11

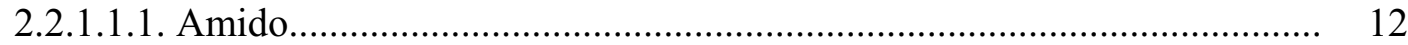

2.2.1.2. Farelo de mandioca................................................................................. 16

2.2.1.2.3. Farinha de soja.............................................................................. 18

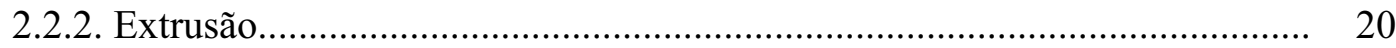

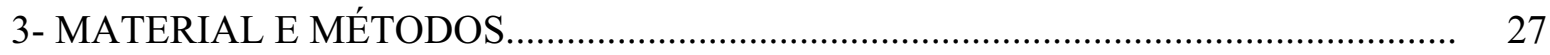

3.1. Caracterização das matérias-primas................................................................... 27

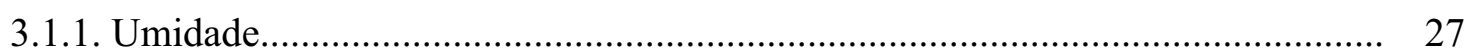

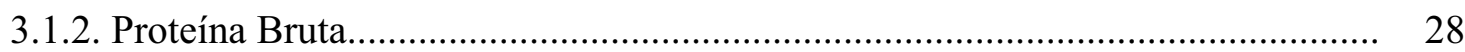

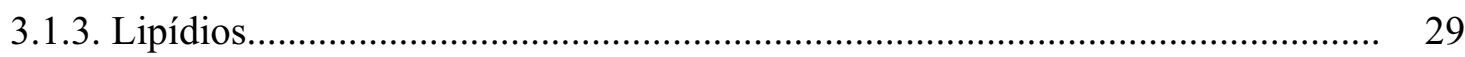

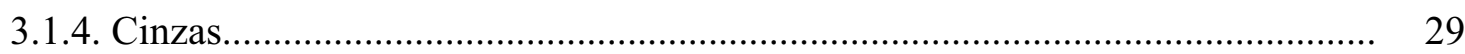

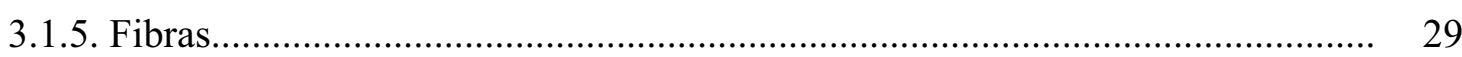

3.1.6. Açúcares Solúveis Totais............................................................................ $\quad 30$

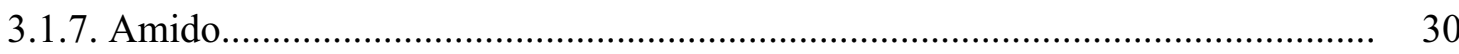

3.1.8. $\mathrm{pH}$

3.1.9. Acidez Titulável.......................................................................................... 31

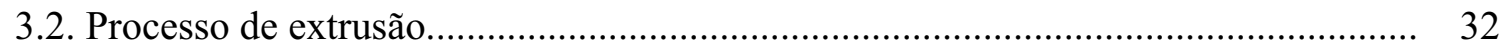




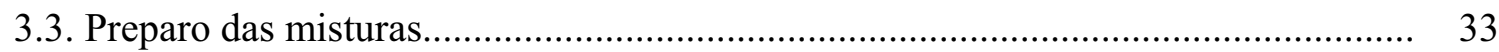

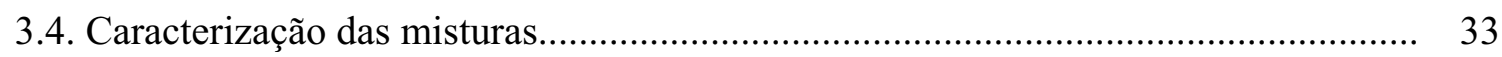

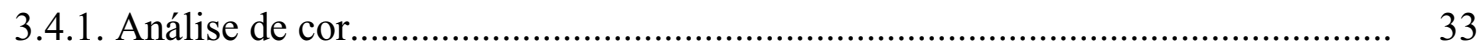

3.4.2. Índice de absorção de agua (IAA) .................................................................. 34

3.4.3. Índice de solubilidade em agua (ISA)...................................................... 34

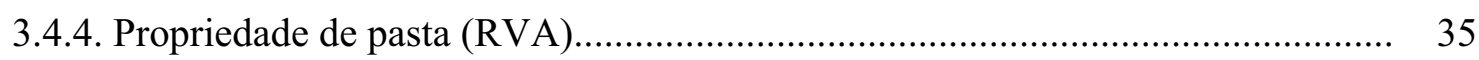

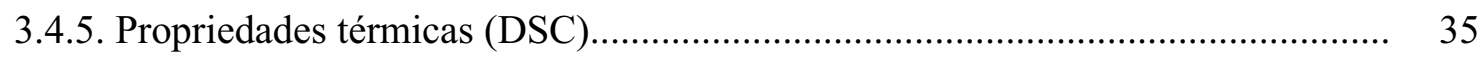

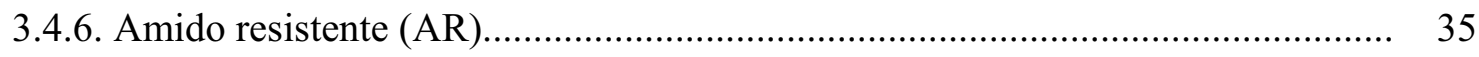

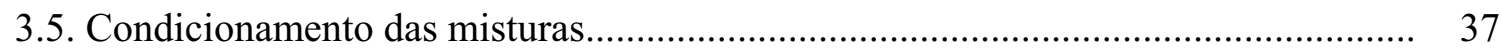

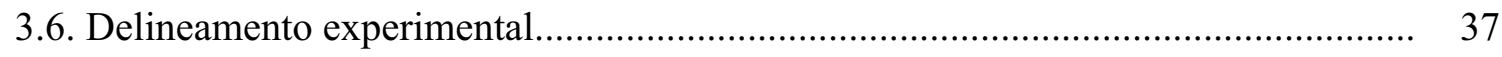

3.7. Análise dos produtos extrusados expandidos......................................................... 38

3.7.1. Índice de expansão (IE) ............................................................................... 38

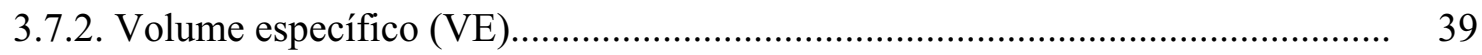

3.8. Análise das farinhas instantâneas............................................................................ 39

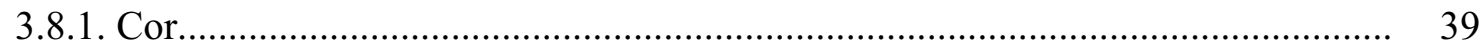

3.8.2. Índice de absorção em água (IAA) ...................................................................... 39

3.8.3. Índice de solubilidade em água (ISA) ........................................................ 40

3.8.4. Propriedades de pasta (RVA) ......................................................................... 40

3.8.5. Propriedades térmicas (DSC) .......................................................................... 40

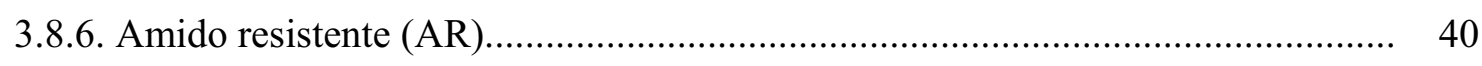

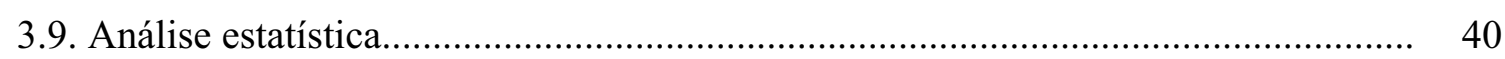

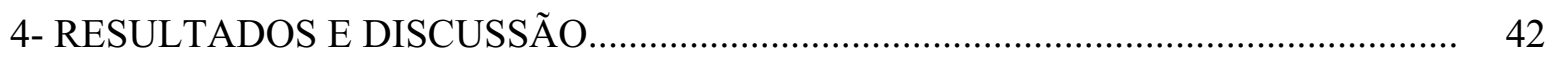

4.1. Caracterização das matérias-primas..................................................................... 42

4.2. Caracterização das misturas............................................................................. 43

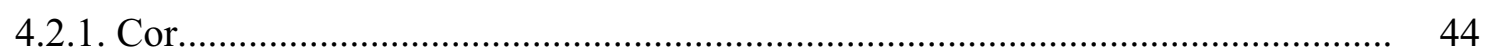

4.2.2. Índices de absorção de água (ISA) e Índices de solubilidade em água

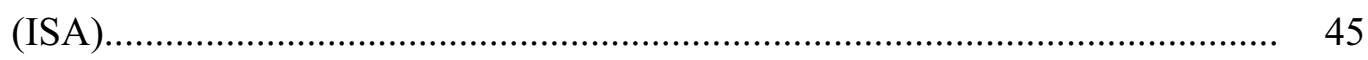

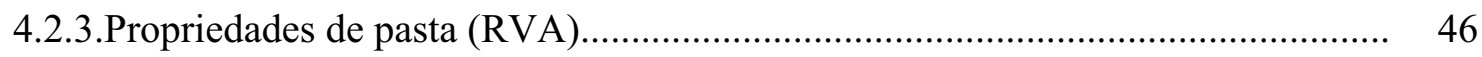

4.2.4.Propriedades térmicas (DSC)..................................................................... 48

4.2.5. Amido resistente nas misturas (AR) ................................................................. 49 
4.3. Caracterização dos produtos expandidos................................................................. 50

4.3.1. Volume específico (VE).............................................................................. 50

4.3.2. Índice de expansão................................................................................. 53

4.4. Análise das farinhas instantâneas........................................................................ 56

4.4.1. Cor .................................................................................... 56

4.4.2. Índices de solubilidade em água (ISA) e índices de absorção em água

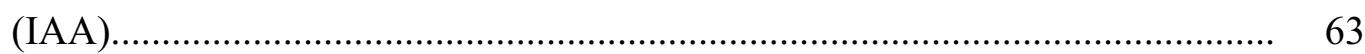

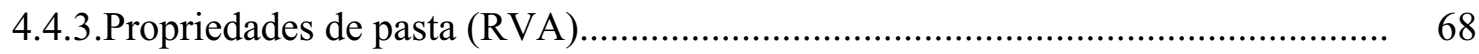

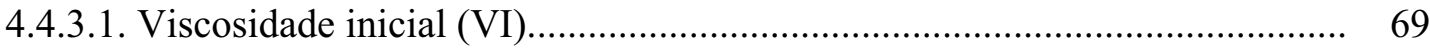

4.4.3.2. Pico de viscosidade (PV) ...................................................................... 72

4.4.3.3. Quebra de viscosidade (QV) ..................................................................... 74

4.4.3.4. Viscosidade final (VF).......................................................................... 76

4.4.3.4. Tendência a retrogradação (TR)............................................................... 78

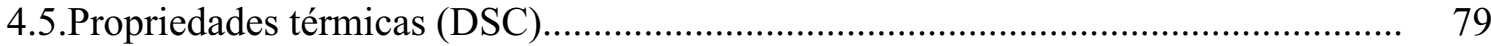

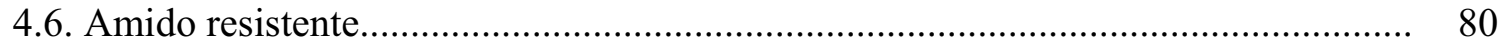

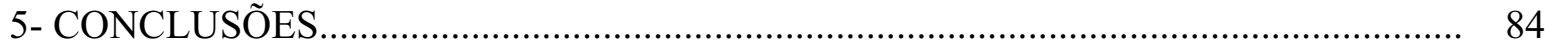

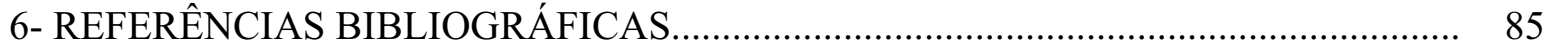




\section{LISTA DE TABELAS}

Página

Tabela 1- Porcentagens de massa seca de fécula, farelo de mandioca e soja em cada mistura.

Tabela 2- Parâmetros variáveis no processo de extrusão

Tabela 3- Composição físico-química média da fécula, farelo de mandioca e farinha de soja.

Tabela 4- Composição química calculada das misturas de fécula, farelo de mandioca e farinha de soja.

Tabela 5- Porcentagem de matéria-prima e luminosidade $\mathrm{L}^{*}$, croma a* e croma $\mathrm{b}^{*}$ das misturas.

Tabela 6- Médias e análise estatística do índice de absorção de água (IAA) e índice de solubilidade (ISA) das misturas de fécula, farelo de mandioca e farinha de soja.

Tabela 7- Propriedades de pasta da fécula, farelo de mandioca, farinha de soja e suas misturas.

Tabela 8- Propriedades térmicas das misturas de farinha de soja, fécula e farelo de mandioca antes do processo de extrusão

Tabela 9- Porcentagens de amido resistente antes da extrusão. 50

Tabela 10- Resultados do índice de expansão e volume específico dos extrusados 51

Tabela 11- Coeficientes de regressão estimados e ANOVA para o volume específico dos 52 produtos

Tabela 12- Coeficientes de regressão estimados e ANOVA para o índice de expansão

Tabela 13- Parâmetros de cor das farinhas extrusadas nas diferentes condições experimentais.

Tabela 14- Coeficientes de regressão estimados e ANOVA para luminosidades ( $\left.\mathrm{L}^{*}\right)$ dos produtos 
Tabela 15- Coeficientes de regressão estimados e ANOVA para croma (a*) dos 60 produtos

Tabela 16- Coeficientes de regressão estimados e ANOVA para croma $\left(b^{*}\right)$ dos produtos.....

Tabela 17- Índice de solubilidade em água (ISA) e índice de absorção em água (IAA) das farinhas extrusadas sob as diferentes condições experimentais

Tabela 18- Coeficientes de regressão estimados e ANOVA para o índice de absorção de água (IAA) das misturas extrusadas.

Tabela 19- Coeficientes de regressão estimados e ANOVA para o índice de solubilidade em água (ISA) das mistura extrusadas.

Tabela 20- Propriedades de pasta das misturas extrusadas nos diferentes tratamentos.

Tabela 21- Coeficientes de regressão estimados e ANOVA para a viscosidade inicial das misturas exrtusadas.

Tabela 22- Coeficientes de regressão e ANOVA para o pico de viscosidade das misturas extrusadas

Tabela 23- Coeficientes de regressão e ANOVA para a quebra de viscosidade das misturas extrusadas.

Tabela 24- Coeficientes de regressão e ANOVA para a viscosidade final das misturas extrusadas

Tabela 25- Coeficientes de regressão estimados e ANOVA para a tendência a retrogradação das misturas extrusadas.

Tabela 26- Resultados médios encontrados para o teor de amido resistente nas misturas extrusadas sob as diferentes condições experimentais

Tabela 27- Coeficientes de regressão estimados e ANOVA para o amido resistente das misturas extrusadas. 


\section{LISTA DE FIGURAS}

Página

Figura 1- Efeito da temperatura de extrusão sobre o volume específico dos extrusados com as porcentagens de farelo de mandioca e farinha de soja em $20 \%$ e rotação de $230 \mathrm{rpm}$

Figura 2- Efeito da porcentagem de farinha de soja e rotação da rosca sobre o índice de expansão dos extrusados, com temperatura em $75^{\circ} \mathrm{C}$.

Figura 3- Efeito da temperatura de extrusão e rotação da rosca sobre o índice de expansão dos extrusados, com porcentagens de farinha de soja e farelo de mandioca à $20 \%$

Figura 4- Efeito da rotação da rosca e da temperatura sobre a luminosidade das misturas extrusadas, com as porcentagens de farelo de mandioca e farinha de soja em $20 \%$

Figura 5- Efeito da porcentagem de farelo de mandioca e farinha de soja sobre a luminosidade das misturas extrusadas, com temperatura de extrusão de $75^{\circ} \mathrm{C}$ e rotação de $230 \mathrm{rpm}$

Figura 6- Efeito da rotação da rosca e da temperatura sobre o croma a* nas misturas após a extrusão, com as porcentagens de farelo de mandioca e farinha de soja em $20 \%$

Figura 7- Efeito da rotação e do teor de farelo de mandioca sobre o croma a* das misturas após a extrusão, com a porcentagem de farinha de soja em $20 \%$ e temperatura de extrusão de $75^{\circ} \mathrm{C}$.

Figura 8- Efeito da temperatura de extrusão sobre o croma b* das misturas extrusadas, com as porcentagens de farelo de mandioca e farinha se soja em $20 \%$ e rotação de $230 \mathrm{rpm}$.

Figura 9- Efeito do teor do farelo de mandioca e farinha de soja nas farinhas extrusadas sobre o croma $\mathrm{b}^{*}$, com a temperatura de extrusão de $75^{\circ} \mathrm{C}$ e rotação de $230 \mathrm{rpm}$. 
Figura 10- Efeito da porcentagem de farinha de soja na mistura e da temperatura de extrusão sobre o índice de absorção de água das misturas, sob rotação de 230 rpm e $20 \%$ de farelo de mandioca na mistura

Figura 11- Efeito da porcentagem do farelo de mandioca na mistura e da temperatura de extrusão sobre o índice de solubilidade em água das misturas, sob rotação de $230 \mathrm{rpm}$ e $20 \%$ de farinha de soja na mistura

Figura 12- Efeito da porcentagem de farinha de soja e farelo de mandioca na mistura sobre a viscosidade inicial das mistura extrusadas, sob temperatura de extrusão de $75^{\circ} \mathrm{C}$ e rotação de $230 \mathrm{rpm}$

Figura 13- Efeito da porcentagem da farinha de soja na mistura e da rotação da rosca sobre a viscosidade inicial das misturas extrusadas, sob temperatura de extrusão de $75^{\circ} \mathrm{C}$ e $20 \%$ de farelo de mandioca na mistura.

Figura 14- Efeito da porcentagem de farinha de soja na mistura e rotação da rosca sobre o pico de viscosidade das misturas extrusadas, sob temperatura de extrusão de $75^{\circ} \mathrm{C}$ e $20 \%$ de farelo de mandioca na mistura

Figura 15- Efeito da porcentagem da farinha de soja na mistura e rotação da rosca sobre a quebra de viscosidade das misturas extrusadas, sob temperatura de extrusão de $75^{\circ} \mathrm{C}$ e $20 \%$ de farelo de mandioca na mistura

Figura 16- Efeito da porcentagem de farinha de soja na mistura e da rotação da rosca sobre a viscosidade final das misturas extrusadas, sob temperatura de extrusão de $75^{\circ} \mathrm{C}$ e $20 \%$ de farelo de mandioca na mistura

Figura 17- Efeito da porcentagem de farinha de soja e farelo de mandioca na mistura sobre a viscosidade final das misturas extrusadas, sob temperatura de extrusão de $75^{\circ} \mathrm{C}$ e rotação de $230 \mathrm{rpm}$

Figura 18- Efeito da porcentagem da farinha de soja e farelo de mandioca na mistura sobre a tendência a retrogradação das misturas extrusadas

Figura 19- Perfil endotérmico observado por DSC das misturas extrusadas.....

Figura 20- Efeito da porcentagem de farinha de soja e farelo de mandioca na mistura sobre o teor de amido resistente nas misturas extrusadas, sob temperatura de extrusão de $75^{\circ} \mathrm{C}$ e rotação de $230 \mathrm{rpm}$ 


\section{RESUMO}

A mandioca é uma tuberosa amilácea de grande potencial energético, podendo ser utilizada tanto para o consumo in natura como para industrialização. Durante o processamento da mandioca para a produção de fécula são geradas quantidades significativas de resíduo fibroso (farelo), o qual apresenta potencialidade de uso como fonte de fibra alimentar. Estudos revelam os benefícios dos alimentos funcionais, o que tem despertado grande interesse de consumidores que desejam incorporar na sua dieta produtos ricos em componentes nutricionais que, além de nutrir, ainda são capazes de proteger o organismo contra doenças. Devido a esses fatores, a soja tem se destacado entre as leguminosas pelos diversos benefícios atribuídos ao seu consumo. A tecnologia de extrusão vem sendo explorada nos últimos anos para o desenvolvimento de novos produtos alimentícios. Essa tecnologia possibilita, com pouca ou nenhuma modificação dos equipamentos básicos e um controle apropriado do processo, a produção de uma grande variedade de produtos. Neste trabalho objetivou-se avaliar o efeito da composição da matéria-prima, da temperatura de extrusão e da rotação da rosca sobre as propriedades físicas e reológicas de produtos extrusados obtidos a partir de misturas de farelo e fécula de mandioca com farinha de soja. O processo de extrusão foi realizado em extrusor mono rosca e seguiu o delineamento "central composto rotacional" 
para quatro fatores ou variáveis independentes para o farelo de mandioca (\%) farinha de soja $(\%)$, temperatura $\left({ }^{\circ} \mathrm{C}\right)$ e rotação $(\mathrm{rpm})$, totalizando 25 tratamentos. A análise dos resultados foi realizada pelo programa SAS. As características avaliadas nos produtos foram: índice de expansão (IE), volume específico (VE), índice de absorção de água (IAA), índice de solubilidade em água (ISA), cor, propriedades térmicas e de pasta. A composição físicoquímica das matérias-primas evidenciou o elevado teor de fibras $(21,77 \%)$ do farelo de mandioca e a elevada porcentagem de proteína da farinha de soja $(46,75 \%)$. Os teores de amido resistente nas misturas variaram de 2,65 a $1,23 \%$ e 1,42 a $0,33 \%$, antes e após o processo de extrusão, respectivamente, ocorrendo efeito significativo do teor de farinha de soja e farelo de mandioca. Os produtos extrusados apresentaram escurecimento independente do tratamento empregado. O índice de expansão e o volume específico foram influenciados pelo teor de fibras, proteínas e a temperatura de processo. Os índices de absorção em água (IAA) e solubilidade em água (ISA) aumentaram seus valores após a extrusão. As propriedades de pasta dos extrusados mostraram diferenças significativas quando comparadas com as misturas antes da extrusão, com aumento da viscosidade inicial e redução dos demais parâmetros. Após a extrusão a análise de dados mostrou não haver entalpia de gelatinização residual nas misturas extrusadas. Biscoitos com maior expansão são obtidos nas condições de elevada temperatura de extrusão $\left(90^{\circ}-150^{\circ} \mathrm{C}\right)$ e rotação da rosca $(270 \mathrm{rpm})$ mantendo as proporções de $20 \%$ de farelo de mandioca e $10 \%$ de farinha de soja misturados à fécula de mandioca. Nas condições de elevada temperatura $\left(90^{\circ}\right.$ a $\left.105^{\circ} \mathrm{C}\right)$ de extrusão e rotação da rosca (270 rpm) e baixa porcentagem de farinha de soja e farelo de mandioca (10\%) é possível obter uma farinha instantânea funcional com alta luminosidade, baixa solubilidade e elevada viscosidade a frio.

Palavras-chave: amido, fibras, proteína, farinha, extrusão. 
CHARACTERIZATION OF EXTRUDED PRODUCTS OF SOY FLOUR, CASSAVA FIBROUS RESIDUE AND CASSAVA FLOUR. Botucatu, 2010. 100p. Dissertação (Mestrado em Agronomia/Energia na Agricultura) - Faculdade de Ciências Agronômicas, Universidade Estadual Paulista.

Author: FERNANDA ROSSI MORETTI TROMBINI

Adviser: MAGALI LEONEL

\section{SUMMARY}

Cassava is a tuberous starch with great energy potential and can be used both for fresh consumption and processing purposes. During the processing of cassava for starch production are generated significant amounts of residual fibers (cassava bran), which has potential use as a source of dietary fiber. Studies show the benefits of functional foods, which has roused the interest of consumers who want to incorporate in your diet products rich in nutrition components, and nurture, are still able to protect the body against diseases. Due to these factors, soy has emerged between the various legumes benefits attributed to its consumption. The extrusion technology has been explored in recent years to the development of new food products. This technology makes it possible, with little or no 
modification of the basic equipment and an appropriate control of the process, the production of a wide variety of products. This work aimed to evaluate the effect of the composition of the raw material, the extrusion temperature and screw speed on physical and rheological properties of extruded products made from mixtures of bran and cassava starch with soy flour. The extrusion process was carried out in single screw extruder and followed central composite rotational design for four factors or independent variables: cassava bran (\%) soybean flour $(\%)$, temperature $\left({ }^{\circ} \mathrm{C}\right)$ and rotation $(\mathrm{rpm})$ including a total of 25 treatments. The analysis was performed by SAS software. The characteristics of the products evaluated were: expansion index (EI), specific volume (SV), water absorption index (WAI), water solubility index (WSI), color, and thermal and paste properties. The physico-chemical composition of raw materials showed the high fiber content $(21.77 \%)$ of cassava bran and the high percentage of protein of soy flour $(46.75 \%)$. The levels of resistant starch ranged from 2.65 to $1.23 \%$ and 1.42 to $0.33 \%$, before and after extrusion, respectively, with significant effect of level of soy flour and cassava bran. The extruded products showed darkening independent of the treatment. The expansion index and specific volume were influenced by fiber content, protein and process temperature. The water absorption (WAI) and water solubility index (WSI) increased their values after extrusion. Pasting properties of extrudates showed significant differences when compared with the mixture before extrusion, with an increase in initial viscosity and reduction of other parameters. After the extrusion data analysis showed no residual gelatinization enthalpy. Extruded products with high expansion are obtained on conditions of high extrusion temperature $\left(90-105^{\circ} \mathrm{C}\right)$ and screw speed $(270 \mathrm{rpm})$ with $20 \%$ of cassava residue and $10 \%$ of soy flour in mixtures. In conditions of high extrusion temperature $\left(90-105^{\circ} \mathrm{C}\right)$ and screw speed (270rpm) and low percentage of cassava residue and soy flour (10\%) it is possible obtain instant flour with low darkness, low water solubility and high cold viscosity.

Keywords: starch, fiber, protein, flour, extrusion 


\section{INTRODUÇÃO}

Um dos indicadores de doenças está relacionado aos hábitos alimentares e ao estilo de vida das pessoas. As mudanças econômicas, níveis de industrialização, a disponibilidade de alimentos, os tipos de trabalho e receitas inovadoras vêm transformando os estilos tradicionais de vida. Dessa forma, houve como conseqüência, mudanças no estado nutricional e um aumento na incidência de doenças crônicas degenerativas.

Existe um acentuado interesse mundial para melhorar a qualidade da nutrição e reduzir os gastos com saúde por meio da prevenção de doenças crônicas, melhoria da qualidade e expectativa de vida ativa. Para se obter essas características é necessário que a Organização Mundial da Saúde apresente uma estratégia global e adoção de políticas que estimulem a alimentação saudável e a prática de atividade física, como forma de diminuir a ocorrência das doenças crônicas não-transmissíveis causadas pela alimentação não-saudável e por estilos de vida sedentários.

A preocupação em manter condições favoráveis de uma vida mais saudável, também está presente em consumidores exigentes e mais informados, os quais estão buscando novas alternativas de alimentos industrializados. Nessa nova tendência, elaborar 
produtos inovadores funcionais incluindo o farelo de mandioca e a farinha de soja com alto valor nutritivo é um desafio para as indústrias.

A raiz de mandioca é eminentemente calórica, gerando cerca de 1500 cal $/ \mathrm{kg}$, a partir dos carboidratos. As raízes apresentam em média 1,55\% de fibras, $33,5 \%$ de carboidratos e 1\% de cinzas (CEREDA, 1994).

Os resíduos gerados no processamento da mandioca são partes constituintes da própria planta gerados em função do processo tecnológico adotado. Tanto a qualidade quanto a quantidade gerada varia de acordo com a cultivar, a idade da planta, tempo pós-colheita, tipo e regulagem do equipamento, entre outros.

A maior parte dos resíduos sólidos gerados durante o processamento da mandioca contém fibras, sendo despejados ao solo como fertilizante ou acrescentados à alimentação do gado e, muitas vezes até se tornando um problema para o industrial que tem como matéria-prima essa amilácea.

Durante o processo de extração da fécula de mandioca é gerado o farelo, massa ou bagaço, caracterizado como material fibroso da raiz, contendo parte do amido que não foi possível extrair no processamento.

O farelo é gerado na etapa de separação do amido e, nesta fase contém cerca de $85 \%$ de umidade. Segundo LEBOURG (1996), o balanço de massa em uma fecularia brasileira que processa em torno de 200 toneladas de raízes/dia é $254,7 \mathrm{~kg}$ de fécula e $928,6 \mathrm{~kg}$ de farelo úmido para cada tonelada de raiz de mandioca processada.

As leguminosas compõem outro grupo vegetal destinado à alimentação, tendo como destaque a soja. Esse grão representa aproximadamente $70 \%$ de todas as sementes oleaginosas produzidas no mundo, sendo que a produção mundial da safra 2008 foi de 210,6 milhões de toneladas, sendo os Estados Unidos o maior produtor mundial (80,5 milhões de toneladas), seguido pelo Brasil (60 milhões de toneladas) e Argentina (47 milhões de toneladas). O complexo agroindustrial mundial desta leguminosa movimenta aproximadamente 230 bilhões de dólares por ano (FAO, 2008).

A soja além da grande importância econômica para o Brasil apresenta características funcionais e nutricionais que fazem com que seja utilizada em vários tipos de alimentos. Produtos à base de soja desempenham papel importante na nova geração de alimentos funcionais, na prevenção de doenças do coração, obesidade, hipercolesterolemia, 
câncer, diabetes, doenças dos rins, osteoporose (GARCIA et al., 1997) e sintomas de menopausa (POTTER et al., 1998). Os efeitos funcionais da soja são atribuídos à proteína, oligossacarídeos, fibras e principalmente aos isoflavonóides (GINSBURG \& PREVELIC, 2000).

O grão de soja é um alimento rico em proteínas, fibras, óleo, importante fonte de minerais (sódio, potássio fósforo, ferro, magnésio, zinco e cálcio) e vitaminas, como tiamina (B1), riboflavina (B2), niacina (B3) ácido nicotínico e ácido ascórbico. Além disso, produtos da soja desempenham função importante para saúde, além de serem utilizados por pessoas alérgicas ao leite e, também, por suas boas características tecnológicas (BAZINET et al., 1997). Produtos contendo proteína de soja ganham espaço no mercado e são produzidos na forma de farinha, texturizados, isolados, substitutos de produtos lácteos, cárneos e panificação. Suas proteínas também são utilizadas em alimentos como ingredientes funcionais e nutricionais como substituto da proteína animal (PUPPO \& ANÕN, 1999).

As proteínas da soja são muito utilizadas no segmento cárneo (embutidos, apresuntados e presuntos) com objetivo de reduzir custos e melhorar características como uniformidade, textura e suculência. Outros produtos à base de soja como iogurte, requeijão, maionese e similares estão sendo desenvolvidos e a tendência é de que ocupem uma fatia importante do mercado (OKADA, 2000). Deste modo, a soja e seus derivados oferecem excelentes possibilidades para serem empregados sob as mais variadas formas, no processamento de produtos alimentícios destinados ao consumo humano, com melhor valor nutritivo e custos reduzidos (TEIXEIRA, 2004).

Pesquisas no ramo alimentício, associadas às tecnologias permitem elaborar uma infinidade de alimentos processados com alta qualidade nutricional. A tecnologia de extrusão, nos últimos tempos, tem se tornado um dos principais processos no desenvolvimento de produtos alimentícios. Alimentos extrusados variam desde cereais para o café da manhã, snacks a partir de diferentes tipos de amidos, a farinhas instantâneas e doces.

A extrusão é um processo contínuo, no qual a matéria-prima é forçada através de uma matriz ou molde, em condições de mistura e aquecimento, pressão e fricção que levam à gelatinização do amido, a desnaturação de proteínas e a ruptura de pontes de hidrogênio (THAKUR \& SAXENA, 2000). 
O controle das condições de extrusão tais como temperatura, teor de umidade e componentes de matéria-prima é essencial para garantir a boa qualidade do produto.

Este trabalho teve como objetivo avaliar os efeitos da composição da matéria-prima e das condições operacionais do processo de extrusão na produção de produtos expandidos em misturas de farinha de soja, fécula e farelo de mandioca visando fornecer informações ao setor de processamento de mandioca, o qual tem grande interesse na implantação de novas tecnologias para o processamento e aproveitamento de resíduos, que levem ao incremento da cadeia produtiva da mandioca no país. 


\section{REVISÃO DE LITERATURA}

\subsection{Alimentos funcionais}

Foi no início da década de 80 que os alimentos funcionais surgiram no Japão. Esse conceito tomou como base a prevenção de doenças crônicas e degenerativas da população idosa que estava em crescente desenvolvimento. Essa preocupação com esses tipos de doenças freqüentes entre os idosos partiu não só do governo, mas também da população.

Alimento funcional é a denominação atribuída ao alimento que, além de suas funções nutricionais, como fonte de energia e de substrato para a formação de células e tecidos, possui, em sua composição, uma ou mais substâncias capazes de agir no sentido de modular os processos metabólicos, melhorando as condições de saúde, promovendo o bem estar das pessoas e prevenindo o aparecimento precoce de doenças degenerativas, que levam a uma diminuição da longevidade (SGARBIERI \& PACHECO, 1999).

No Brasil, a tendência é de classificar como alimentos funcionais fisiológicos, aqueles alimentos que, pela sua composição, irão produzir no organismo efeitos benéficos à saúde, que vão além das funções estritamente nutricionais, modulando processos bioquímico-fisiológicos que resultem em benefícios para a saúde. $\mathrm{O}$ alimento funcional deverá 
constituir parte da dieta normal, inclusive quanto à apresentação e forma de consumo. A adição de nutrientes aos alimentos, aqui no Brasil, é regulamentada pela Portaria $n^{\circ} 31$, de 13 de janeiro de 1998, da Secretaria de Vigilância Sanitária do Ministério de Saúde (BRASIL, 1998).

Dentre os componentes dos alimentos com funcionalidade fisiológica pode-se citar, entre os nutrientes: os polissacarídeos, como a fibra; os ácidos graxos poliinsaturados da família ômega-3, como o EPA (ácido eicosapentaenóico) e o DHA (ácido docosahexaenóico); algumas vitaminas; minerais essenciais; proteínas e peptídeos, e, entre os não-nutrientes: os oligossacarídeos; os flavonóides, como as isoflavonas da soja; os carotenóides, como o licopeno do tomate; os fitoesteróis; compostos organosulfurados; compostos fenólicos; limonóides e substâncias indólicas (SGARBIERI \& PACHECO, 1999; LAJOLO, 2001).

Os grãos e seus derivados, como farinhas e farelos integrais, juntamente com as frutas e hortaliças são as principais fontes de fibra alimentar. Do ponto de vista químico, os constituintes da fibra alimentar podem ser divididos em componentes nãoglicerídios, polissacarídeos não-amido e amido resistente, que além do efeito terapêutico, fornece uma melhor textura, aparência e sabor (CHARALAMPOPOULOS et al., 2002).

Quanto às propriedades físico-químicas, a fibra alimentar é composta de uma fração insolúvel e outra solúvel em água (SGARBIERI \& PACHECO, 1999). A fração insolúvel é formada principalmente de celulose, lignina e hemiceluloses insolúveis. Essa fração exerce um efeito físico-mecânico, aumentando o volume do bolo alimentar e das fezes diminuindo o tempo de trânsito intestinal. Esses componentes, ao se hidratarem, ligam não somente água, mas também elementos minerais, vitaminas, sais biliares, hormônios e lipídios, dificultando a absorção e aumentando a excreção dessas substâncias (SGARBIERI, 1996).

A fração solúvel forma uma rede de gel ou uma rede viscosa, em determinadas condições físico-químicas, e desta forma ligam água, o que aumenta a capacidade de retenção de água e absorção lipídica. Elas são vistas como substratos fermentativos que podem alterar a microflora e conduzir a uma redução ou modificação dos agentes mutagênicos (THEBAUDIN et al., 1997). 


\subsection{Processo de extrusão}

\subsubsection{Matérias-primas}

\subsubsection{Fécula de mandioca}

De acordo com a legislação brasileira amido é o produto amiláceo extraído das partes aéreas comestíveis dos vegetais (sementes, etc.), e fécula é o produto amiláceo extraído das partes subterrâneas comestíveis dos vegetais (tubérculos, raízes e rizomas). O produto é designado "amido" ou "fécula", seguido do nome do vegetal de origem. Ex.: "amido de milho", "fécula de batata" (BRASIL, 1978).

A mandioca é cultura amplamente difundida por todo o território nacional. Sua utilização é feita em duas opções para consumo doméstico ("de mesa”) ou industrial, pelo qual se processa a farinha e procede-se a extração de fécula e sua transformação em polvilho azedo. A dimensão da cultura é também variada, indo das plantações de fundo de quintal até as extensivas, mais comuns no sudeste do país.

O Brasil ocupa a segunda posição na produção mundial de mandioca, produzindo cerca de 25,9 milhões de toneladas/ano, perdendo para a Nigéria (44,9 milhões de toneladas/ano) e Tailândia (27,7 milhões toneladas/ano) e no mundo gera o equivalente a 232,9 milhões de toneladas/ano (FAO, 2008). A mandioca é cultivada em todas as regiões do Brasil, assumindo destacada importância na alimentação humana e animal, além de ser utilizada como matéria-prima em inúmeros produtos industriais. Tem ainda papel importante na geração de emprego e de renda, notadamente nas áreas pobres da Região Nordeste.

A fécula de mandioca é um produto de mercado mundial crescente, sendo a Tailândia o maior produtor mundial e também a maior exportadora de fécula de mandioca, chips e pelets, para alimentação animal. Sozinho, esse país representa cerca de $80 \%$ do comércio internacional de fécula de mandioca (VILPOUX, 2006).

Segundo Saito (2005), a extração da fécula é essencialmente um

processo físico de separação onde as raízes são lavadas e descascadas, sendo a seguir trituradas em pequenos pedaços, os quais são moídos para que as paredes das células vegetais possam liberar o amido. Nessa operação são utilizadas cevadeiras que reduzem a polpa com 
granulometria entre 550 a $350 \mu \mathrm{m}$ e, deste modo, a massa é bombeada para peneiras rotativas chamadas GLs que retiram o amido liberado, lixiviando com água através de telas com malhas de $100 \mu \mathrm{m}$. O leite de amido é lavado novamente com água e separado em centrífugas que o disponibiliza para concentração e secagem final em secadores tipo Flash drier.

\subsection{Amido}

O amido é um polissacarídeo que consiste de $\alpha$-D-glicose, cujas ligações glicosídicas são identificadas por átomos de carbono numerados de 1 a 6 . Essas numerações facilitam a compreensão das propriedades e reatividade dos grupos funcionais da molécula de glicose anidra no amido (BULÉON et al., 1998).

Os grânulos de amido apresentam diferentes formas e tamanhos conforme a fonte botânica, sendo compostos basicamente por duas macromoléculas, amilose e amilopectina, que se apresentam em proporções relativamente constantes de 20:80, mas podem apresentar quantidades relativas de $2 \%$ de amilose em amidos cerosos, até cerca de 80\% de amilose, no "amilomilho" (BULÉON et al., 1998).

Características relacionadas à estrutura dos grânulos de amidos tais como teor de amilose, distribuição de comprimento de cadeias ramificadas da amilopectina (JANE et al., 1999; FRANCO et al., 2002b), teores de monoesterfosfato, fosfolipídeos e lipídeos, entre outros, afetam profundamente as propriedades funcionais de amidos.

$\mathrm{O}$ amido é largamente usado pela indústria de alimentos nacional e internacional como melhorador das propriedades funcionais em sistemas alimentícios. Relações entre as características estruturais de amidos e suas propriedades térmicas e de pasta tem recebido muita atenção.

Grânulos de amido são insolúveis em água fria, mas quando aquecidos, ocorre um inchamento irreversível dos grânulos, produzindo uma pasta viscosa (WHISTLER \& BeMILLER, 1997). Este fenômeno é conhecido como gelificação do amido e depende de vários fatores como a fonte do amido, concentração deste e temperatura durante $\mathrm{o}$ aquecimento (MORIKAWA \& NISHINARI, 2000). Gelificação é definida como o colapso, ruptura, da ordem molecular dentro do grânulo de amido, manifestada em mudanças 
irreversíveis nas propriedades, tais como: aumento de tamanho granular, fusão de cristais, perda da birrefringência e solubilização do amido (THOMAS \& ATWELL, 1999). Ocorre acima de uma determinada temperatura, com grânulos maiores gelificando primeiro e os menores, depois. A temperatura inicial de gelificação depende do método de medida e da relação amido-água, tipo de grânulo e heterogeneidade dentro do grânulo. As mudanças que ocorrem nos grânulos de amido durante a gelificação e retrogradação são os principais determinantes do comportamento de pasta desses amidos, as quais têm sido medidas principalmente pelas mudanças de viscosidade durante o aquecimento e resfriamento de dispersões de amido usando equipamentos como viscoamilógrafo Brabender e mais recentemente, o rápido viscoanalizador (RVA) (THOMAS \& ATWELL, 1999).

No RVA, durante a fase inicial de aquecimento de uma suspensão aquosa de amido, um aumento na viscosidade é registrado quando os grânulos começam a inchar. Neste ponto polímeros com baixo peso molecular, particularmente moléculas de amilose, começam a ser lixiviadas dos grânulos. Um pico de viscosidade é obtido durante o empastamento, quando existe a maioria dos grânulos totalmente inchados, grânulos intactos e o alinhamento molecular de qualquer polímero solubilizado ainda não ocorreu dentro do campo de atrito do instrumento (WHISTLER \& BeMILLER, 1997). Durante a fase de temperatura constante $\left(95^{\circ} \mathrm{C}\right)$ os grânulos começam a se quebrar e a solubilização dos polímeros continua. Neste ponto ocorre uma quebra na viscosidade seguida de diminuição. Durante a fase de resfriamento, polímeros de amilose e amilopectina solubilizados começam a se reassociar e outro aumento na viscosidade é registrado. Este segundo aumento da viscosidade é conhecido como tendência a retrogradação ou set-back.

Geralmente, para aqueles amidos que são facilmente gelificados, quanto maior o teor de amilose, maior o set-back. Dependendo do tipo de amido (fonte botânica, amido natural ou modificado), do $\mathrm{pH}$ da suspensão aquosa e da programação de aquecimento, vários perfis de gelificação e empastamento podem ser gerados (WHISTLER \& BeMILLER, 1997).

O amido de mandioca, estudado por Rickard et al., (1991), mostrou alto grau de inchamento, resultando em alto pico de viscosidade seguido de rápida quebra no gel. Durante o período de resfriamento, sua consistência aumenta muito pouco, indicando baixo potencial para formação do gel. A tendência a retrogradação do amido de mandioca 
pode ser determinada pela afinidade dos grupos hidroxilas de uma molécula para outra ocorrendo principalmente entre as moléculas de amilose, e sua baixa tendência a retrogradação pode ser devido ao peso molecular da fração de amilose.

$\mathrm{O}$ estudo do comportamento térmico de amidos, incluindo temperaturas de gelificação, retrogradação, temperatura de transição vítrea e cristalização foram nos últimos vinte anos muito estudados utilizando-se o Calorímetro Diferencial de Varredura (DSC) (YU \& CHRISTIE, 2001), o qual mede a quebra de ligações (principalmente ligações de hidrogênio que estabilizam as duplas hélices) dentro dos grânulos de amido quando eles são aquecidos em água e quantifica a temperatura e energia envolvida (entalpia) na transição de um grânulo semi-cristalino para um gel amorfo. Esta técnica pode também ser empregada para medir maiores transições de temperaturas em amidos quando complexos amilose-lipídeo se dissociam (TESTER, 1997).

O comportamento térmico de amidos é muito mais complexo do que a termoplasticidade convencional causada pelas mudanças físico-químicas que ocorrem durante o aquecimento de amidos ou produtos amiláceos que envolvem gelificação, fusão, transição vítrea, cristalização, mudanças da estrutura cristalina, expansão do volume, degradação molecular e movimentação da água.

Todos esses comportamentos térmicos dependem do teor de umidade e da quantidade de água contida no amido durante o aquecimento instável (YU \& CHRISTIE, 2001).

Stevens \& Elton (1971 apud YU \& CHRISTIE 2001), foram os primeiros a apresentarem as aplicações do DSC para medidas de temperaturas de gelificação e retrogradação do amido. O termo gelificação é muito usado para descrever o evento molecular associado ao aquecimento do amido em excesso de água, causando um inchamento irreversível, no qual envolve a dissolução de duplas hélices. O amido é convertido de uma forma semicristalina para uma amorfa. Cada amido tem suas temperaturas características de gelificação, To, Tp e Tc (temperaturas inicial, de pico e de conclusão, respectivamente) e sua entalpia de gelificação $(\Delta \mathrm{H})$ obtidas do DSC (TESTER, 1997). Depois de atingida a temperatura de conclusão (Tc), toda dupla hélice da amilopectina é dissociada, embora a expansão da estrutura granular possa ser conservada até que temperaturas mais altas e 
cisalhamento sejam aplicados. Acima de $95^{\circ} \mathrm{C}$ um gel amorfo é formado. O intervalo de temperatura Tc-To representa o período de gelificação (BLENNOW et al., 2000).

A cristalinidade do amido pode ser estimada pela entalpia $(\Delta \mathrm{H})$ requerida para fundir os segmentos de duplas hélices. As temperaturas de gelificação (inicial e de pico) podem ser usadas como medida da estabilidade ou perfeição das regiões cristalinas, e a largura do pico endotérmico como estimativa da heterogeneidade da estrutura cristalina (BLENNOW et al., 2000).

O amido é classificado em função da sua estrutura físico-química e da sua susceptibilidade à hidrólise enzimática. Segundo Englyst et al., (1992), de acordo com a velocidade com a qual o alimento é digerido in vitro, o amido divide-se em: rapidamente digerível, lentamente digerível e amido resistente (AR) que resiste à ação das enzimas digestivas. Segundo esse mesmo autor, o amido rapidamente digerível é convertido em glicose em 20 minutos pela ação da amilase pancreática e amiloglucosidase à $37^{\circ} \mathrm{C}$; o lentamente digerível nas mesmas condições anteriores se converte em glicose em 120 minutos; e amido resistente (AR) é aquele que resiste à ação das enzimas digestivas. Este último pode ser definido como aquele que resiste à hidrólise enzimática, e consequentemente não é absorvido/digerido no intestino delgado de indivíduos saudáveis, podendo ser fermentado no intestino grosso (EERLINGER \& DELCOUR, 1995).

Uma outra grande importância do amido resistente são os efeitos fisiológicos que ocorrem, pois o amido não digerido ao chegar ao cólon é utilizado por diversas bactérias intestinais, principalmente as anaeróbias estritas (bacteróides, eubactérias, bifidosbactérias e Clostridium) que constituem $99 \%$ da flora intestinal humana, sendo assim considerado um agente prebiótico. O resultado desta fermentação produz ácidos graxos de cadeia curta (AGCC), acético, propiônico e butírico e gases como hidrogênio, dióxido de carbono e metano dos quais cerca de $20 \%$ são excretadas pela respiração (TOPPING \& CLIFTON, 2001). Os butiratos têm um efeito benéfico na redução dos fatores de risco envolvidos na etiologia do câncer de cólon e desenvolvimento de adenomas (TOOPING \& CLIFTON, 2001; FERREIRA, 2003; CAMBRODON \& MARTIN-CARRON, 2001). Estudos in vitro verificaram que os butiratos são agentes anti-neoplásicos e experimentos realizados verificam um efeito protetor de fibras em roedores. Velazquez et al., (1996) verificou em estudos que a ação do butirato promoveu o crescimento e desenvolvimento de células 
saudáveis no intestino e conseqüentemente inibindo processos degenerativos e doenças que produzem células anormais.

Segundo Pereira (2007), o amido resistente é um componente natural da dieta. O consumo atual é cerca de $3 \mathrm{~g} /$ pessoa/dia e é encontrado em alimentos não processados como grãos, batata crua, banana verde, ou mesmo em alimentos processados e retrogradados como a casca de pão ou batata cozida resfriada.

Certos processos alimentícios como esterilização, forneamento ou secagem em altas temperaturas aumentam o nível de amido resistente. Entretanto, outros procedimentos como cozimento, os amidos perdem sua resistência.

Os amidos resistentes também apresentam características físicas únicas que se traduzem em propriedades funcionais que podem destacar o alimento (PEREIRA, 2007). Com essas características o amido processado industrialmente pode ser modificado enzimaticamente, fisicamente ou quimicamente. Aplicações de amidos resistentes são apropriadas para a maioria dos produtos de baixa umidade. Estudos mostram que o amido resistente proporciona melhor aparência e textura do que fontes de fibras convencionais, e melhoram a expansão e crocância em certas aplicações em alimentos (PEREIRA, 2007).

\subsubsection{Farelo de mandioca}

As mudanças na economia fizeram com que as indústrias revisassem seus processos e também a qualidade dos seus produtos, frente às exigências de mercados cada vez mais competitivos. Os processos passaram a serem considerados como um todo, onde os resíduos gerados passaram a serem vistos como receitas potenciais (LEONEL, 2001).

As unidades de processamento da mandioca para produção de fécula e polvilho azedo produzem um material sólido identificado por farelo, bagaço ou polpa residual, o qual tem sido sub-aproveitado na alimentação de animais. Massa, farelo ou bagaço é o resíduo sólido composto pelo material fibroso da raiz, contendo parte do amido que não foi possível extrair no processamento. É gerado na etapa de separação da fécula, e por embeber-se de água, em volume, apresenta maior quantidade que a própria matéria-prima, contendo cerca de $75 \%$ de umidade. Esse resíduo sólido, após parcialmente seco, tem, em média, a 
composição $10 \%$ de umidade, $15 \%$ de fibras e 75\% de amido, apresentando pH 5,5 (LEONEL, 2000).

Devido à problemática ambiental decorrente dessa atividade agroindustrial, diversos estudos foram realizados visando o uso deste resíduo como matériaprima para a produção de xarope de glicose, etanol e de produto alimentício fibroso para a alimentação humana (RAUPP et al., 2002).

Segundo Mendonça et al., (2000) produtos que eram descartados ou usados para alimentação animal, como exemplo, os subprodutos de milhares de indústrias, são hoje em dia largamente aplicados em alimentos, o que indica que o uso dos resíduos do processamento de mandioca apresenta-se como uma ferramenta essencial para o maior desenvolvimento das empresas do setor.

O farelo de mandioca caracteriza-se por ser um resíduo sólido com elevada umidade (85\%), e após a desidratação apresenta 76,32\% de amido e 9,9\% de fibras, com baixas porcentagens de outros componentes (LEONEL et al., 2008).

Segundo Cereda (1994) o farelo de mandioca apresenta 7\% de fibra dietética, sendo $6 \%$ insolúvel e $1 \%$ solúvel.

As fibras alimentares têm cada qual, efeitos fisiológicos diferentes. Em geral, as fibras solúveis em água (pectinas, gomas, mucilagens e certas hemiceluloses) retardam a passagem intestinal, o esvaziamento gástrico e absorção de glicose, ajudando a reduzir o colesterol no soro sanguíneo. As fibras insolúveis em água (lignina, celulose e algumas hemiceluloses) aceleram o trânsito intestinal, aumentam o peso das fezes, desaceleram a hidrólise do amido e retardam a absorção da glicose, contribuindo para a redução do risco de alguns males do cólon (LEONEL et al., 1999).

Frente aos benefícios de uma dieta com alto teor de fibra, baixa caloria e nutricionalmente balanceada, têm ocorrido um aumento no consumo de alimentos com essas características, levando a incorporação de fibras em vários novos produtos, o que justifica o interesse no aproveitamento do farelo para este fim. 


\subsubsection{Farinha de soja}

Originária da China, a soja pertence à família Leguminosae e ao gênero Glycine, que compreende cerca de 15 espécies, sendo a comercial a Glycine max. Os grãos de soja são duros, geralmente amarelos e tem formato semelhante ao de uma ervilha. É um dos mais antigos vegetais usados na alimentação do homem, sendo consumida há séculos em diversas regiões do Continente Asiático (SIMONETTI, 199-).

Uma das principais, características da soja como alimento, é o seu alto teor de proteínas. A proteína dos alimentos fragmenta-se em aminoácido durante o processo de digestão, o que é absorvido e distribuído pela corrente sanguínea gerando diversos benefícios à saúde (SIMONETTI, 199-).

Vários estudos têm demonstrado que o consumo dos grãos ou produtos derivados de soja está frequentemente associado com a redução do risco de inúmeras doenças, tais como câncer de esôfago, pulmão, próstata, mama e cólon/reto, doenças cardiovasculares, osteoporose, diabetes e sintomas da menopausa (CHUNG, et al.; 1996; GALLAGHER, et al.; 2004), e isso fez com que o consumo da soja na alimentação humana quadruplicasse nos últimos cinco anos, atingindo em 2002, 4\% do total produzido no Brasil (HAN, et al.; 2002).

Outros compostos presentes na soja de grande interesse são as isoflavonas, um tipo de fito-hormônio, que desempenham papel importante na prevenção de doenças crônico degenerativas e, particularmente, naquelas associadas com hormônios, reduzindo fortemente os efeitos indesejáveis da menopausa, em populações consumidoras de soja, além de possuírem atividade antioxidante protegendo o organismo contra danos celulares (KIM et al., 1998).

O processamento da soja dá origem a diferentes matérias-primas como farinhas de soja, extratos hidrossolúveis e proteínas texturizadas que podem ser utilizados na produção de alimentos que fazem parte da dieta ocidental (GENOVESE \& LAJOLO, 2002). Nos últimos anos, a procura por alimentos derivados de soja tem aumentado devido à divulgação dos benefícios à saúde atribuídos ao consumo desta leguminosa.

Segundo a ANVISA (2009), o consumo diário de no mínimo $25 \mathrm{~g}$ de proteína de soja pode ajudar a reduzir o colesterol. A quantidade de proteína de soja, contida 
na porção do produto pronto para consumo, deve ser declarada no rótulo, próximo alegação No caso de produtos nas formas de cápsulas, tabletes, comprimidos e similares, deve-se declarar a quantidade de proteína de soja na recomendação diária do produto pronto para o consumo, conforme indicação do fabricante. Os dizeres de rotulagem e o material publicitário dos produtos à base de soja não podem veicular qualquer alegação em função das isoflavonas, seja de conteúdo (contém), funcional, de saúde e terapêutica (prevenção, tratamento e cura de doenças)

A soja é um alimento rico em proteínas, fibra, óleo, importante fonte de minerais (sódio, potássio, fósforo, ferro, magnésio, zinco e cálcio) e vitaminas como tiamina $\left(\mathrm{B}_{1}\right)$, riboflavina $\left(\mathrm{B}_{2}\right)$, niacina $\left(\mathrm{B}_{3}\right)$, ácido nicotínico e ácido ascórbico. Além disso, produtos da soja desempenham função importante para a saúde, além de serem utilizados por pessoas alérgicas ao leite e também por suas boas características tecnológicas (BAZINET et al., 1997).

As principais propriedades funcionais da proteína de soja são: capacidade de retenção de água, emulsificação, gelatinização e formação de espuma (GARCIA et al., 1997).

Segundo Santos (2006), a incorporação de isolado protéico de soja no pão de queijo, além de conferir propriedades nutricionais e funcionais (MARTINS \& NETO, 2006) melhora a capacidade de hidratação e estabilidade coloidal, e funciona como agente de corpo, melhorando a maciez do produto final.

Segundo Máximo (199-), a aplicação de farinha de soja em confeitaria e na produção de biscoitos é praticamente ilimitada. Tanto pode ser usada como agente branqueador e como meio de melhorar as características de sabor e torragem, como para prolongar a vida dos produtos ajudando a conservar a umidade. A farinha de soja facilita o manuseio da massa. Em bolinhos fritos, ajuda a reduzir a quantidade de gordura absorvida no processo de frituras.

Deste modo, a soja e seus derivados oferecem excelentes possibilidades para serem empregados sob as mais variadas formas, no processamento de produtos alimentícios, com melhor valor nutritivo e baixo custo. 


\subsubsection{Extrusão}

O princípio básico do processo de extrusão é converter um material sólido em fluido pela aplicação de calor e trabalho mecânico e extrusá-lo através de uma matriz. O processo promove a gelatinização do amido, a desnaturação e re-orientação das proteínas, a inativação enzimática, a destruição de substâncias tóxicas, tais como os inibidores das proteases, e a diminuição da contagem microbiana para formar um produto de características físicas e geométricas pré-determinadas (SEBIO, 1996). Além disso, proporciona a hidratação de amidos e proteínas, homogeneização, cisalhamento, fundimento de gorduras, plastificação e expansão da estrutura alimentar (FELLOWS, 2002).

Segundo Gutkoski (2000) dentre as aplicações da extrusão em alimentos, pode-se citar a produção de cereais matinais e expandidos, farinhas e amido prégelatinizados, produtos texturizados, produtos de confeitaria, bebidas, alimentos ricos em fibras. O processo pode também promover a inativação de fatores anti-nutricionais e enzimáticos. Além do que, a brevidade do tratamento térmico reduz o dano a nutrientes termosensíveis como certos aminoácidos e vitaminas (HARPER, 1979).

Segundo El-Dash (1982) o processo de extrusão compreende as etapas de pré-extrusão, extrusão e pós-extrusão. A pré-extrusão inclui a preparação dos ingredientes e sua mistura em proporção adequada. Após a mistura, o material é transportado para ser condicionado a um conteúdo apropriado de umidade. Na etapa de extrusão, a matéria-prima é introduzida no equipamento através do alimentador, sendo impulsionada pelo(s) parafuso(s) em direção à matriz. À medida que o produto atravessa as diferentes zonas de extrusão (de alimentação, de transição e de alta pressão), ocorre aumento gradativo do atrito mecânico, provocado por modificações da geometria do parafuso e abertura da matriz. Em conseqüência, aumentam também a pressão e a temperatura, ocorrendo o cozimento do produto. A pósextrusão inclui a secagem dos extrusados expandidos para umidades inferiores a $10 \%$, o resfriamento e a aplicação de sabores e temperos.

A extrusão está diretamente influenciada pelas variáveis independentes do processo. As variáveis independentes (YACU, 1990) são aquelas que controlam diretamente os atributos de qualidade, tais como: composição dos ingredientes alimentares, umidade, o tamanho de suas partículas, a velocidade de alimentação do parafuso, a 
configuração do parafuso e da matriz, a temperatura, a pressão e o tempo de residência. Já as variáveis dependentes mudam como conseqüência das variáveis independentes e servem para avaliar as propriedades físicas, químicas e funcionais dos extrusados sendo estas: densidade, volume específico, umidade, expansão, atributos sensoriais como aparência, sabor, crocância, textura, grau de cozimento avaliado através da susceptibilidade enzimática, viscosidade, índices de absorção e de solubilidade em água, a difração de raio-X e calorimetria.

Segundo Smith (1976), o processo de extrusão tem muitas vantagens como, uma grande variedade de produtos pode ser produzida em um sistema básico de extrusão com uma capacidade de produção maior que outros sistemas de cozimento, além de ter requerimentos de trabalho e espaço por unidade de produção menor, bem como, extrusores produzem formas que não são facilmente obtidas com outros métodos de produção. A alta temperatura e o curto tempo do processo minimiza a degradação dos nutrientes ao mesmo tempo em que destrói microrganismos. A extrusão pode ainda modificar proteínas vegetais, amidos e outros materiais para produzir novos alimentos sem deixar resíduos nem materiais perigosos para o meio ambiente.

É importante o controle do processo de extrusão para permitir a obtenção de produtos com características variadas, como também melhorar a eficiência e economia da operação. Embora a extrusão seja um processo tecnológico simples, seu controle é complicado devido ao grande número de variáveis envolvidas no processo e sua complexidade (CARVALHO, 2000).

As mudanças físicas resultantes do processamento são determinantes para a aceitabilidade do produto final, e, para "snacks" são características importantes: expansão, dureza, crocância e densidade. È esperada uma estrutura expandida na maioria dos “snacks" (CHRISTOFIDES et al., 2004; BOMBO, 2006).

A formação de produtos expandidos, com forma e textura desejáveis, depende de inúmeros fatores. Os mais importantes são: a gelatinização adequada do amido e o desenvolvimento de zonas de alta pressão próximas à matriz, para causar rápida evaporação da água e formação de uma estrutura celular forte (CAMIRE et al., 1990).

Para Fellows (2002), os dois principais fatores que influenciam nas características dos produtos extrusados são: as características das matérias-primas e as condições operacionais do extrusor. Como principais características para a matéria-prima são 
destacadas as seguintes: tipo de material, teor de umidade, estado físico, composição química (teores e tipos de amidos, proteínas, fibras, gorduras e açúcares) e $\mathrm{pH}$ do material. Já, como parâmetros operacionais são apontados como importantes: temperatura, pressão, diâmetro da matriz e taxa de cisalhamento, sendo esta última influenciada pelo desenho interno do extrusor e pelo seu comprimento; além da velocidade e geometria da (s) rosca (s).

$\mathrm{O}$ teor de umidade do material que será extrusado afeta significativamente a expansão e foi considerada a variável mais importante do processo. Em produtos amiláceos quanto menor a umidade, maior a expansão (GOMEZ \& AGUILERA, 1983).

A extrusão, dependendo das condições de processamento e das misturas entre os ingredientes alimentares, causa intumescimento e ruptura dos grânulos de amido, solubilidade em água fria, viscosidade reduzida e liberação parcial ou completa da amilose e da amilopectina. Embora seja difícil conhecer precisamente as várias combinações de temperatura, umidade, cisalhamento e tempo de residência os quais trazem diferentes graus de gelatinização de amido em diferentes misturas de alimentos, a gelatinização completa do amido é geralmente adquirida em temperaturas maiores ou iguais a $120^{\circ} \mathrm{C}$, percentual de umidade de 20 a $30 \%$ ou mesmo em umidade mais baixas (10-20\%) sob alto cisalhamento e temperatura alcançada durante a extrusão. Tais condições do processamento também permitem a hidrólise da amilose e amilopectina em maltodextrinas (HARPER, 1978).

As principais propriedades funcionais do amido, extrusado e disperso em água, são a absorção e a solubilidade nesta. Como é conhecido, o amido nativo não absorve água a temperatura ambiente sendo sua viscosidade praticamente nula. Entretanto, o material amiláceo extrusado absorve água rapidamente formando uma pasta a temperatura ambiente, a qual é formada por macromoléculas solubilizadas e também inclui partículas intumescidas por água (gel). Quanto menor a partícula maior a velocidade e seu nível de solubilização.

Os índices de absorção de água (IAA) e solubilidade em água (ISA) são explicados pelas interações amido-água e são importantes na avaliação da adequabilidade do uso de produtos amiláceos extrusados em suspensões ou em soluções. Assim, as alterações do amido no extrusor dependem dos parâmetros do processo tais como velocidade e configuração do parafuso, temperatura, taxa de fluxo do material, configuração da matriz e das 
características do material (proporção de amilose/amilopectina, teor de umidade, granulometria e tipo de grânulos) (CARVALHO, 2000).

Os índices de absorção (IAA) e de solubilidade em água (ISA) podem ser usados para estimar a conveniência de se usarem ou não produtos extrusados de amido em suspensões ou soluções (CARVALHO, 2000).

O ISA está relacionado à quantidade de sólidos solúveis em uma amostra seca, permitindo verificar o grau de severidade do tratamento, em função da degradação, gelatinização, dextrinização e conseqüente solubilização do amido (CARVALHO et al., 2002).

Estudando os efeitos das variáveis do processo de extrusão no amido de milho através da gelatinização, do indice de solubilidade em água (ISA) e do índice de absorção de água (IAA), Owusu-ansah et al.; (1983) verificaram que o ISA aumentou com a elevação da temperatura e a umidade das amostras, enquanto o IAA aumentou com o incremento da temperatura até um valor máximo e diminuiu a seguir devido à excessiva dextrinização. Todas as medidas físico-químicas indicaram um certo grau de hidrólise do amido durante o processo, e um aumento do grau de gelatinização com o aumento da temperatura e do teor de umidade.

Chang et al., (2001) utilizaram a Metodologia de Superfície de Resposta (MSR) para estudar os efeitos dos parâmetros da extrusão termoplástica (umidade inicial da matéria-prima e temperatura de processo) e adição de concentrado protéico de soja no desenvolvimento de snacks extrusados à base de amido de mandioca, e concluíram que o maior índice de absorção de água foi obtido quando utilizados maiores níveis de umidade e de concentrado protéico, e que a diminuição do teor de concentrado protéico levou á um menor índice de solubilidade em água.

A principal mudança físico-química que ocorre com a proteína durante a extrusão é a melhora da digestibilidade devido à desnaturação, pela aplicação de calor úmido e cisalhamento, e a inativação de inibidores de enzimas. São fatores que interferem na digestibilidade da proteína durante a extrusão: aumento da temperatura, aplicação de calor anterior ao processamento, origem da proteína, velocidade de rotação da rosca (CAMIRE et al., 1990). Já a principal mudança química é a ocorrência da reação de Maillard acarretando 
diminuição da disponibilidade de lisina, principalmente em condições de elevada temperatura, alta rotação, baixa umidade e presença de açúcares redutores (CHEFTEL, 1986).

Ferreira (1999) cita que durante a extrusão as proteínas nativas passam por uma total desagregação, com a fusão em uma suspensão homogênea que propicia a desnaturação, dissociação e formação de filamentos que se alinham no sentido do fluxo até a expulsão da máquina. Nas transformações químicas da desnaturação, as forças de estabilização das estruturas terciárias e quaternárias da proteína são enfraquecidas pela combinação da temperatura alta e da compressão dentro do extrusor. São rompidas ligações iônicas, dissulfeto, pontes de hidrogênio e interações fracas, do tipo Van der Waals. Com essa desnaturação surgem proteínas com diferentes pesos moleculares, bem como aminoácidos até então indisponíveis, podendo ocorrer reação com açúcares redutores e outros componentes (reação de Maillard).

Faubion et al., (1982) usando isolado de soja e glúten de trigo, encontraram que estas proteínas, quando extrusadas, possuem efeitos opostos na expansão. $\mathrm{O}$ isolado protéico adicionado a 7,5\% no amido de trigo causou um aumento de $25 \%$ na expansão. Por outro lado, mas mesmas condições, a adição do glúten causou $14 \%$ de redução na expansão. Estes efeitos poderiam ser explicados devido às diferenças nas propriedades químicas das duas proteínas, que possuem efeitos diferentes na hidratação e gelatinização do amido.

Altas taxas de lipídeos prejudicam a expansão. Todavia, lipídeo presente em pequenas quantidades (até 5\%) facilita a extrusão e melhora a textura. O valor nutricional dos lipídeos pode ser afetado durante a extrusão como um resultado de oxidação, hidrogenação, isomerização ou polimerização. Foi observado que a formação de isômeros trans ocorreu em taxas muito baixas, não mostrando importância nutricional (CAMIRE et al., 1990).

As fibras alimentares são constituintes normais da parede das células vegetais, resistentes à hidrólise enzimática no intestino humano, embora parcialmente atacadas pelas bactérias do cólon.

A incorporação de altos níveis de fibra dietética em produtos extrusados tem freqüentemente resultado em produtos compactos, rígidos, com baixo índice de expansão. Hashimoto \& Grossman (2003), avaliando as condições do processo de extrusão 
na qualidade de produtos extrusados de farelo e amido de mandioca, observaram que os produtos com maiores volumes específicos foram obtidos nas condições de 16 e 18\% de umidade, e $180-200^{\circ} \mathrm{C}$. A maior expansão foi obtida nos produtos com menor quantidade de farelo (10\%). Já os índices de solubilidade em água (ISA) e absorção de água (IAA) foram afetados pelo teor de farelo de mandioca, rotação da rosca e temperatura. $\mathrm{O}$ aumento na proporção de farelo levou a um aumento no IAA e um decréscimo do ISA em temperaturas superiores a $170^{\circ} \mathrm{C}$.

Leonel et al., (2008), estudando o efeito da temperatura de extrusão de biscoito de polvilho azedo com fibras, obteve um ISA maior nas condições de temperaturas elevadas, acima de $65^{\circ} \mathrm{C}$, o que mostra a interferência desse parâmetro na degradação do amido de mandioca. Enquanto que, para o IAA os maiores valores foram obtidos nos tratamentos sem fibras. A incorporação de fibras à mistura reduz muito o IAA sob alta umidade, entretanto, sob baixos teores de umidade (12\%) o efeito da adição de fibras não é tão acentuado.

A viscosidade de pasta de produtos extrusados é uma das propriedades mais importantes de misturas instantâneas. A curva de viscosidade representa o comportamento durante o aquecimento e permite avaliar as características da pasta formada, devido às modificações estruturais das moléculas de amido, e de outros componentes.

Martins et al., (2009), estudando misturas extrusadas de polvilho azedo e farinha de soja integral, mostraram que nas condições de menor porcentagem de farinha de soja nas misturas, a viscosidade inicial dos produtos extrusados é maior, decrescendo acentuadamente com o aumento da farinha de soja. Uma característica marcante de misturas extrusadas é a de não apresentar aumento de viscosidade com o abaixamento da temperatura de $95^{\circ} \mathrm{C}$ para $50^{\circ} \mathrm{C}$. Esse fenômeno talvez possa ser explicado pela baixa retrogradação do amido após a extrusão e pela incapacidade das proteínas, já desnaturadas pelas extrusão, formarem géis, mediante aquecimento e resfriamento (ALVIM et al., 2002).

A extrusão provoca alterações em várias propriedades funcionais do amido, como é o caso do amido resistente. O cozimento por esse processo tecnológico, em geral, aumenta significativamente a digestibilidade do amido quando comparado com os amidos não extrusados, devido à ruptura da estrutura física do grânulo de amido e a 
gelatinização, caracterização pelo aumento da viscosidade a frio (HAGENIMANA et al., 2006).

Freitas \& Leonel (2008) estudando o efeito de condições operacionais de extrusão sobre o teor de amido resistente (AR) em fécula de mandioca observaram um teor de AR de 4,15\% antes da extrusão. Após a extrusão ocorreu redução do teor de AR, sendo que a temperatura de extrusão teve efeito significativo sobre este parâmetro, seguida pela interação da umidade da fécula com a rotação da rosca.

A cor é um dos parâmetros de qualidade em produtos extrusados a qual é influenciada pelas condições operacionais e composição da matéria-prima. A formação de cor durante o processo de extrusão proporciona importante informação a respeito do grau do tratamento térmico. Menegassi et al., (2007), avaliando a cor para farinha de mandioquinha-salsa, obteve diferenças significativas para luminosidade, croma $a^{*}$, croma $b^{*}$. O componente, luminosidade das farinhas extrusadas, variou de 65 a 67, indicando a redução da luminosidade com a extrusão, quando comparado com a luminosidade da farinha crua que foi 85,8 . Também houve aumento da cromaticidade $a^{*}$ apresentando valores de 4 a 10 superiores ao da farinha crua que foi de 1,72 . Já a coordenada de cromaticidade b* que após a extrusão ficou entre 30 e 37, a mesma farinha antes desse processo foi de 15,75. 


\section{MATERIAL E MÉTODOS}

\subsection{Caracterização das matérias-primas}

Foram utilizadas como matérias-primas neste projeto a farinha de soja comercial (Jasmim), a fécula de mandioca (Halotek-Fadel S/A), e o farelo de mandioca (Flor de Lótus).

As matérias-primas foram caracterizadas quanto à umidade, proteína, lipídeos, cinzas, fibras, açúcares solúveis totais, amido, $\mathrm{pH}$ e acidez titulável, conforme as metodologias descritas a seguir.

\subsubsection{Umidade}

Cadinhos de porcelana foram levados em estufa a $105^{\circ} \mathrm{C}$ durante 2 horas. Após esse período, foram esfriados em dessecador e pesados. Pesou-se aproximadamente $3 \mathrm{~g}$ de amostra e os cadinhos foram deixados em estufa por 8 horas, retirados em dessecador e pesados até manter o peso constante (AOAC, 1975). 


\section{Cálculo: Peso cadinho com amostra seca - peso do cadinho vazio $\mathrm{x} 100=$ E.S.T \\ Peso da amostra \\ $\%$ Umidade $=$ E.S.T $($ extrato seco total $)-100$}

\subsubsection{Proteína Bruta}

Foi colocado em balão de Kjeldahl 0,2g de amostra. Adicionado 0,5g de mistura digestora e $4 \mathrm{ml}$ de ácido sulfúrico concentrado. Foi digerido em bloco digestor dentro de capela até que o líquido estivesse límpido (azul claro). Foi transferido com auxílio de água destilada o produto da digestão para o tubo do destilador. Pipetado $10 \mathrm{ml}$ da solução de ácido bórico a $1 \%$ e transferido para o erlenmeyer de $125 \mathrm{ml}$. Adaptado o erlenmeyer ao refrigerador do aparelho de destilação de maneira que sua extremidade ficasse mergulhada na solução de ácido bórico. Transferido para o reservatório do aparelho de destilação microKjeldahl, através de copo abastecedor, aproximadamente $30 \mathrm{ml}$ da solução de hidróxido de sódio a 50\%. Este copo foi lavado com pequenas porções de água destilada. Destilou-se aproximadamente um volume de $75 \mathrm{ml}$. Titulou-se o destilado com solução de ácido sulfúrico $0,01 \mathrm{~N}$ em microbureta. Também foi feito uma prova em branco, usando mistura digestora e ácido sulfúrico. Esta análise foi calculada através da determinação do nitrogênio pelo método de Kjedahl usando o fator $\mathrm{f}=6,25$ para conversão (AOAC, 1975).

$$
\text { Cálculo }=\% \text { Nitrogênio }=(\mathrm{V}-\mathrm{A}) \times 0,00014 \times 100 / \mathrm{P}
$$

Onde:

$\mathrm{A}=$ valor da titulação da prova em branco;

$\mathrm{V}=$ valor da titulação da amostra;

$\mathrm{P}=$ peso inicial da amostra; 


\subsubsection{Lipídeos}

Pesou-se $3 \mathrm{~g}$ de amostra em cartucho feito com papel comum para a determinação de matéria graxa. Acoplado em conjunto de Soxleh com balões de tara conhecida e devidamente anotada. Adicionado sobre os cartuchos $200 \mathrm{ml}$ de éter de petróleo. O banho-maria do conjunto foi ligado e deixado em refluxo por 12 horas. Os balões foram retirados e o éter foi evaporado em estufa de ar circulante a $105^{\circ} \mathrm{C}$ por 2 horas. Decorrida estas etapas os balões foram retirados e esfriados em dessecador e pesados (AOAC, 1975).

\section{Cálculo: \% matéria graxa $=\underline{(\text { Peso do balão com óleo }- \text { Peso do balão }) \times 100}$}

Peso da amostra

\subsubsection{Cinzas}

Os cadinhos vazios de tara conhecida foram levados em estufa à $105^{\circ} \mathrm{C}$ por 2 horas. Retirados e esfriados em dessecador, pesados e tarados novamente. Pesou-se $3 \mathrm{~g}$ de amostra que foi levado em mufla até atingir a temperatura de $505^{\circ} \mathrm{C}$ (mantendo a porta semi-aberta até atingir a temperatura de $400^{\circ} \mathrm{C}$ ), e depois fechada. Atingido $505^{\circ} \mathrm{C}$, a mufla foi desligada baixando a temperatura gradualmente para $200^{\circ} \mathrm{C}$. Os cadinhos com a amostra calcinada foram esfriados em dessecador e pesados (AOAC, 1975).

Cálculo: $\%$ Cinzas $=\underline{\text { Peso do cadinho com cinzas }- \text { Peso do cadinho vazio } \times 100}$

Peso da amostra

\subsubsection{Fibras}

Uma amostra de $2 \mathrm{~g}$ foi transferida para o tubo de digestão, acrescentando-se $200 \mathrm{ml}$ de solução de $\mathrm{H}_{2} \mathrm{SO}_{4}$ a 1,25\% (p/v), em seguida levado a ebulição branda por 30 minutos. O material foi filtrado em um funil, com papel de filtro já tarado, com o auxílio de água destilada. O processo foi repetido utilizando-se de $200 \mathrm{ml}$ de solução de $\mathrm{NaOH} 1,25 \%(\mathrm{p} / \mathrm{v})$. Depois da filtragem, o papel de filtro mais amostra foi levado à estufa a 
$105^{\circ} \mathrm{C}$ até secagem completa ( 8 horas), retirado em dessecador para esfriar por 2 horas, e depois, pesado (AACC, 1975). Cálculo:

Cálculo: \% Fibra alimentar (bruta) = peso do papel + resíduo seco - peso do papel x 100 Peso da amostra

\subsubsection{Açúcares Solúveis Totais}

$\mathrm{Na}$ determinação dos açúcares solúveis totais $0,5 \mathrm{~g}$ de amostra foi colocada em um erlenmeyer de $250 \mathrm{~mL}$ onde se acrescentou $30 \mathrm{~mL}$ de etanol absoluto P.A. e $30 \mathrm{~mL}$ de água destilada, tampados com papel alumínio e levando ao banho com aquecimento entre $60-65^{\circ} \mathrm{C}$ por 60 minutos, com agitação mecânica constante e branda. Depois, se acrescentou $1 \mathrm{~mL}$ de HCL P.A. concentrado e agitou-se, retornando ao banho por mais uma hora na mesma temperatura. Após este tempo a amostra foi resfriada e transferida para balão volumétrico de $250 \mathrm{~mL}$ efetuando-se a neutralização com solução de NAOH. Em seguida foi feita à diluição num balão de $100 \mathrm{~mL}$ a qual foi filtrada em papel simples e no material filtrado foi dosado o teor de açúcares solúveis totais (SOMOGY, 1945 \& NELSON, 1944).

\section{Cálculo: \% Somogy Nelson $=\underline{\mathrm{A} \%} \cdot \mathrm{D} . \mathrm{K} \cdot 100$}

1.000 .000

Onde:

$\mathrm{A} \%=$ absorbância da amostra;

$\mathrm{K}=$ constante da curva padrão de glicose;

$\mathrm{D}=$ diluição do material inicial;

\subsubsection{Amido}

A determinação de amido foi realizada pelo método enzimático. A amostra de $200 \mathrm{mg}$ peneirada acrescentou-se $42 \mathrm{~mL}$ de água destilada e $1 \mathrm{~mL}$ de solução comercial de alfa-amilase (Termamyl 120L- Novo Nordisk) a 50\% (v/v). Após estes procedimentos os erlenmeyers foram levados ao banho-maria, com agitação suave, a $90^{\circ} \mathrm{C}$, 
durante 2 horas. Junto se realizou uma prova em branco. Nas amostras dextrinizadas as quais foram acrescentadas $2,5 \mathrm{~mL}$ de solução tampão acetato $2 \mathrm{M}$, de $\mathrm{pH} 4,8$ e $5 \mathrm{~mL}$ de solução recém preparada e filtrada de Amiloglucosidase EC 3.2.1.3 de Rhyzopus SP (Sigma), na concentração de $10 \mathrm{mg} / \mathrm{mL}$. Os erlenmeyers com as amostras mais a prova em branco foram levados ao banho-maria com agitação contínua a $60{ }^{\circ} \mathrm{C}$ por 2 horas. Logo após, retirou-se a amostra hidrolisada a qual foi resfriada até a temperatura ambiente e corrigido o $\mathrm{pH}$ entre 7 e 9 com NAOH a $4 \mathrm{M}$ e transferindo para um balão volumétrico de $250 \mathrm{~mL}$. O volume foi completado com água destilada e $5 \mathrm{~mL}$ desta diluição foi transferida para um balão volumétrico de $100 \mathrm{~mL}$, completado com água destilada, filtrado em papel simples e dosado o teor de açúcares redutores (SOMOGY, 1945 \& NELSON, 1944).

$$
\text { Cálculo: \% Somogy Nelson }=\frac{\mathrm{A} \% \text {. D . K . } 100}{1.000 .000}
$$

Onde:

A\% = absorbância da amostra;

$\mathrm{K}=$ constante da curva padrão de glicose;

$\mathrm{D}=$ diluição do material inicial;

\subsection{8. pH}

Foram pesadas $10 \mathrm{~g}$ da amostra em um becker de $250 \mathrm{~mL}$, adicionando-se $100 \mathrm{~mL}$ de água destilada. Foi agitado em agitador magnético durante 30 minutos, sendo em seguida deixado em repouso por 10 minutos. Decantando o líquido sobrenadante para um frasco seco e imediatamente o $\mathrm{pH}$ foi determinado ao inserir o eletrodo do $\mathrm{pH}$-metro na amostra (IAL, 1985).

\subsubsection{Acidez Titulável}

Após o pH ter sido determinado, manteve-se o pH-metro ligado. Sob agitação magnética constante, titulou-se com a solução padronizada de $\mathrm{NaOH}$ a $0,1 \mathrm{~N}$ até atingir o pH 8,2 a 8,3 no pH-metro, anotando-se o volume gasto (IAL, 1985). 
Cálculo: Acidez Normal em ml/100g de amostra $=\underline{\text { V .F . } 100}$

$\mathrm{P}$

Onde:

$\mathrm{V}=$ quantidade de $\mathrm{NaOH}$ em $\mathrm{ml}$ gastos na titulação;

$\mathrm{F}=$ Normalidade da solução de $\mathrm{NaOH}$ usadas $(0,01$ ou $0,1 \mathrm{~N})$;

$\mathrm{P}=$ Peso em $\mathrm{g}$ da amostra

\subsection{Processo de extrusão}

A extrusão foi efetuada em uma linha completa de extrusão IMBRA $\mathrm{RX}$ da Inbramaq S/A com motor de $10 \mathrm{HP}$ acoplado a um redutor de velocidade, sistema de extrusão através de fricção mecânica, rosca simples de extrusão, sistema de refrigeração hidráulica para controle de temperatura na camisa de extrusão, velocidade variável e capacidade de produção de $45 \mathrm{Kg} / \mathrm{h}$. Os parâmetros de processamento foram divididos em parâmetros variáveis e fixos.

\section{Parâmetros Variáveis:}

- Temperatura de extrusão na terceira zona;

- Porcentagem de farelo de mandioca;

- Porcentagem de farinha de soja

- Rotação

\section{Parâmetros Fixos:}

- Umidade das misturas: 17\%;

- Taxa de compressão da rosca $3: 1$;

- Taxa de alimentação: $200 \mathrm{~g} / \mathrm{min}$;

- Abertura da matriz: 3mm;

- Temperatura na $1^{\mathrm{a}}$ zona e $2^{\mathrm{a}}$ zona: $25^{\circ} \mathrm{C}$ e $50^{\circ} \mathrm{C}$, respectivamente. 


\subsection{Preparo das misturas}

Foram preparadas $700 \mathrm{~g}$ de misturas de fécula, farelo de mandioca e farinha de soja, nas proporções do delineamento experimental. A quantidade de fécula de mandioca nas misturas foi variada de acordo com as porcentagens que foram testadas para $o$ farelo de mandioca e farinha de soja completando 100\%. As matérias-primas foram misturadas em batedeira planetária ARNO (Tabela 1).

Tabela 1- Porcentagens de massa seca de fécula, farelo de mandioca e farinha de soja em cada mistura.

\begin{tabular}{cccc}
\hline Misturas & \multicolumn{3}{c}{ Matérias-primas } \\
\hline & $\begin{array}{c}\text { Fécula } \\
(\%)\end{array}$ & $\begin{array}{c}\text { Farelo de mandioca } \\
(\%)\end{array}$ & Farinha de soja (\%) \\
\hline 1 & 70 & 15 & 15 \\
2 & 60 & 25 & 15 \\
3 & 60 & 15 & 25 \\
4 & 50 & 25 & 25 \\
5 & 70 & 10 & 20 \\
6 & 50 & 30 & 20 \\
7 & 70 & 20 & 10 \\
8 & 50 & 20 & 30 \\
9 & 60 & 20 & 20 \\
\hline
\end{tabular}

\subsection{Caracterização das misturas}

\subsubsection{Análise de cor}

A cor das misturas foi avaliada em colorímetro Minolta $C R-400$. Os resultados foram expressos em valores $\mathrm{L}^{*}, \mathrm{a}^{*}$ e $\mathrm{b}^{*}$, onde os valores de $\mathrm{L}^{*}$ (luminosidade ou brilho) variam do preto (0) ao branco (100), os valores do croma a* variam do verde (-60) ao vermelho $(+60)$ e os valores do croma $b^{*}$ variam do azul ao amarelo, ou seja, de $(-60)$ a $(+60)$, respectivamente. 


\subsection{2. Índice de absorção de água (IAA)}

Para a determinação do índice de absorção de água em um tubo de centrífuga (com tampa) previamente foram colocados aproximadamente $2,5 \mathrm{~g}$ de amostra e 30 $\mathrm{ml}$ de água a $25^{\circ} \mathrm{C}$. Os tubos foram agitados durante 30 minutos num agitador mecânico e, em seguida, centrifugados a 3000 rpm por 10 minutos. Do líquido sobrenadante foi coletada uma alíquota de $10 \mathrm{ml}$ e colocada em cadinho de porcelana tarado que foi levado à estufa $\left(105^{\circ} \mathrm{C}\right)$ por 8 horas. O tubo com o gel remanescente foi pesado sendo que o peso do resíduo da evaporação foi obtido pela diferença de peso do cadinho multiplicada por três e, o peso do resíduo da centrifugação, pela diferença de peso do tubo (ANDERSON et al.; 1969).

O IAA foi calculado conforme a seguinte equação:

$$
\mathrm{IAA}=\frac{\text { PRC X } 100}{\mathrm{PA}-\mathrm{PRE}}
$$

Onde:

$\mathrm{PRC}=$ peso de resíduo de centrifugação $(\mathrm{g} ;)$

PA $=$ peso da amostra (base seca);

$\mathrm{PRE}=$ peso de resíduo de evaporação $(\mathrm{g})$;

\subsection{3. Índice de solubilidade em água (ISA)}

O índice de solubilidade em água foi calculado pela relação entre o peso do resíduo de evaporação (PRE) e o peso seco da amostra (PA), conforme a equação:

$$
\mathrm{ISA}=\frac{\mathrm{PRE}}{\mathrm{PA}}
$$

Onde:

$\mathrm{PRE}=$ peso de resíduo de evaporação $(\mathrm{g})$;

$\mathrm{PA}=$ peso da amostra (base seca) 


\subsubsection{Propriedade de pasta}

Para a análise das propriedades de pasta foi utilizado o Rapid Visco Analyser (RVA). As suspensões de amostras (3,5g amostra em $25 \mathrm{ml}$ de água) foram corrigidas para a base de $15 \%$ de umidade e passaram pelo programa de tempo e temperatura Extrusion 1 do software Thermocline for Windows, versão 2.2. Do gráfico obtido foram avaliadas as seguintes características: temperatura de pasta, viscosidade máxima (pico), queda de viscosidade ou "breakdown" (diferença entre a viscosidade máxima e a viscosidade da pasta mantida a $95^{\circ} \mathrm{C}$ por 5 minutos), viscosidade final e tendência a retrogradação (diferença entre a viscosidade final e a viscosidade da pasta a $50^{\circ} \mathrm{C}$ por 5 minutos). A viscosidade foi expressa em RVU (NEWPORT SCIENTIFIC, 1998).

\subsubsection{Propriedades térmicas}

As propriedades térmicas foram analisadas utilizando-se um calorímetro diferencial de varredura (DSC) Pyris 1 (Perkin Elmer, USA). Amostras das misturas e farinhas ( $4 \mathrm{mg}$ base seca) foram pesadas em cadinhos de alumínio, misturadas com água destilada ( $12 \mu \mathrm{l})$ e seladas. Os cadinhos foram mantidos à temperatura ambiente, por $2 \mathrm{~h}$, para equilíbrio e aquecidos a uma razão de $5^{\circ} \mathrm{C} \min ^{-1}$ de 25 a $100^{\circ} \mathrm{C}$. Um cadinho vazio foi usado como referência. As temperaturas de gelatinização (inicial, de pico e final) e a variação de entalpia $(\Delta \mathrm{H})$ das misturas e das farinhas foram determinadas utilizando-se o software Pyris 1 da Perkin Elmer, USA.

\subsubsection{Amido resistente}

O método utilizado foi o proposto por Goñi et al., (1992); consistindo em um processo enzimático, calculando-se o conteúdo final de amido resistente pela concentração de glicose liberada e analisada. Uma amostra de $100 \mathrm{mg}$ de material amiláceo, 
peneirado em peneira ABNT 100, foi colocada em um erlenmeyer de $50 \mathrm{~mL}$. Em seguida foram adicionados $10 \mathrm{~mL}$ de $\mathrm{KCl} / \mathrm{HCl}, \mathrm{pH} 1,5(0,2 \mathrm{M})$, e $0,1 \mathrm{~mL}$ de solução de pepsina $(0,3 \mathrm{~g}$ de pepsina Sigma P-7012 em $10 \mathrm{~mL}$ de solução tampão $\mathrm{KCl} / \mathrm{HCl}$ pH 1,5). A amostra foi mantida em banho de água a $40^{\circ} \mathrm{C}$ por 60 minutos, sob agitação constante. Após esse período, a amostra foi resfriada em temperatura ambiente. Já resfriada, foram adicionados na amostra 9 $\mathrm{mL}$ de tampão Trismaleate (Acros 26497-0260), pH 6,9 (0,1M) e $1 \mathrm{~mL}$ de solução $\alpha$-amilase (4g de $\alpha$-amilase Sigma A-3176 em $100 \mathrm{~mL}$ de tampão Trismaleate). Em seguida a amostra foi incubada em banho de água a $37^{\circ} \mathrm{C}$ por 16 horas, com agitação constante.

Após esses procedimentos, a amostra foi filtrada em papel (Quanty) de $28 \mu \mathrm{m}$, e o líquido foi descartado. O resíduo foi lavado com $10 \mathrm{~mL}$ de água destilada, sendo o líquido descartado novamente.

Em um béquer, com a ajuda de uma espátula, foi colocado o resíduo que ficou no filtro juntamente com $3 \mathrm{~mL}$ de água destilada.

A amostra do béquer foi transferida novamente para um erlenmeyer de $50 \mathrm{~mL}$ e então foram adicionados $3 \mathrm{~mL}$ de $\mathrm{KOH}(2 \mathrm{M})$. Agitou-se a amostra, em temperatura ambiente, por 30 minutos. Foram adicionados $5,5 \mathrm{~mL}$ de $\mathrm{HCl}(1 \mathrm{M}), 3 \mathrm{~mL}$ de tampão sódio acetato, $\mathrm{pH} 4,75$ e $80 \mu \mathrm{l}$ de amiloglucosidase $(0,144 \mathrm{~g}$ de amiloglicosidase Sigma A-7255 em $10 \mathrm{~mL}$ de água destilada). Então a amostra foi levada ao banho de água a $60^{\circ} \mathrm{C}$ por 45 minutos, sob agitação constante.

A amostra foi filtrada novamente em filtro de papel (Quanty) de 28 $\mu \mathrm{m}$ e o resíduo lavado com $10 \mathrm{~mL}$ de água destilada. O resíduo foi descartado.

A concentração de glicose do líquido restante foi determinada pelo método de glicose oxidase (LABORLAB), em espectrofotômetro. Para isso, foi colocado em cada tubo de ensaio $20 \mu 1$ de amostra, $2 \mathrm{~mL}$ do reativo de trabalho de glicose-oxidase. Em seguida o tubo foi tampado e levado ao banho em água a $37^{\circ} \mathrm{C}$ por 10 minutos. Após esse período, o tubo foi resfriado em água corrente. A leitura foi feita em espectrofotômetro com comprimento de onda de $505 \mathrm{~nm}$. O equipamento foi zerado com o branco (20 $\mu 1$ de água destilada e $2 \mathrm{~mL}$ do reativo). 
Para avaliar as leituras de absorbâncias foi feito uma curva padrão de glicose com o reativo de trabalho utilizado nas análises, sendo os resultados expressos em \% de amido resistente.

\subsection{Condicionamento das misturas}

A umidade das misturas foi determinada segundo o método AACC, (1975). Foi necessário o ajuste da umidade das misturas para o parâmetro fixo de $17 \%$. Este condicionamento foi realizado com água destilada adicionada lentamente com pipeta e manteve-se agitação constante na batedeira por 5 minutos. A quantidade de água que foi adicionada às amostras foi calculada pela equação:

$$
\mathrm{Y}=\frac{(\mathrm{Uf}-\mathrm{Ui}) \times \mathrm{Pa}}{100-\mathrm{Uf}}
$$

Onde:

$\mathrm{Y}=$ quantidade de água a ser adicionada (ml);

$\mathrm{Uf}=$ umidade final da amostra;

$\mathrm{Ui}=$ umidade inicial da amostra;

$\mathrm{Pa}=$ peso da amostra $(\mathrm{g})$;

\subsection{Delineamento experimental}

Planejamentos experimentais baseados em princípios estatísticos permitem a obtenção do maior número possível de informações sobre o sistema em estudo através da realização de um número mínimo de experimentos (BARROS NETO et al., 2003).

A Metodologia de Superfície de Resposta (MSR) é uma técnica de otimização baseada no emprego de planejamentos experimentais fatoriais e, tem sido empregada em estudos sobre os efeitos dos parâmetros do processo de extrusão sobre as características físicas, reológicas e funcionais de produtos extrusados. 
O processo seguiu o delineamento "central composto rotacional" para quatro fatores, segundo Cochran \& Cox (1957), com um total de 25 tratamentos, a saber:

- 16 tratamentos correspondentes ao fatorial $2^{4}$, onde os quatro fatores são:

$\mathrm{R}=$ rotação da rosca $(\mathrm{rpm}) ; \mathrm{T}=$ temperatura na $3^{\mathrm{a}}$ zona $\left({ }^{\circ} \mathrm{C}\right), \mathrm{FM}=$ farelo de mandioca $(\%) \mathrm{e}$ $\mathrm{FS}=$ farinha de soja (\%), cada qual em dois níveis, codificados como -1 e +1 ;

- 8 tratamentos com níveis mínimo e máximo de cada fator, codificados como $-\alpha \mathrm{e}+\alpha$, respectivamente, sendo $\alpha=2^{4 / 4}=2$;

- Um tratamento central repetido 6 vezes, onde os fatores estão todos em um nível médio, codificado como zero (Tabela 2).

Tabela 2. Parâmetros variáveis do processo de extrusão.

\begin{tabular}{cccccc}
\hline & Níveis & \multicolumn{4}{c}{ Fatores ou variáveis independentes } \\
\hline Axiais & Codificados & FM & FS & T & $\mathrm{R}$ \\
$-\alpha$ & -2 & 10 & 10 & 45 & 190 \\
& -1 & 15 & 15 & 60 & 210 \\
& 0 & 20 & 20 & 75 & 230 \\
& +1 & 25 & 25 & 90 & 250 \\
$+\alpha$ & +2 & 30 & 30 & 105 & 270 \\
\hline
\end{tabular}

FM: farelo de mandioca (\%); FS: Farinha de soja (\%); T: Temperatura de extrusão $\left({ }^{\circ} \mathrm{C}\right)$; R: rotação da rosca (rpm).

\subsection{Análise dos produtos extrusados expandidos}

\subsection{1. Índice de expansão (IE)}

O índice de expansão dos extrusados foi calculado pela relação entre o diâmetro da amostra e o diâmetro da matriz, conforme a metodologia proposta por Faubion \& Hoseney (1982). O valor considerado foi obtido pela média aritmética das medidas de 15 diferentes extrusados dentro de cada tratamento. 


\subsubsection{Volume específico (VE)}

O volume específico dos produtos expandidos foi determinado pelo método do deslocamento da massa ocupada (semente de painço) e determinado o seu volume em uma proveta graduada. Para o cálculo foi utilizada a fórmula:

$$
\text { Cálculo: } \mathrm{V}=\mathrm{v} / \mathrm{p}
$$

Onde:

$\mathrm{V}=$ volume específico $(\mathrm{ml} / \mathrm{g})$;

$\mathrm{v}=$ volume $(\mathrm{mL})$

$\mathrm{p}=\operatorname{massa}(\mathrm{g})$

\subsection{Análises das farinhas instantâneas}

Os extrusados expandidos foram moídos em moinho de faca da marca Marconi e acondicionados em embalagens plásticas.

\subsubsection{Cor}

A cor das farinhas extrusadas foi avaliada instrumentalmente utilizando-se as mesmas condições segundo a metodologia descrita no item 3.4.1.

\subsection{2. Índice de absorção de água (IAA)}

Para a determinação do índice de absorção de água seguiu-se a metodologia descrita no item 3.4.2. 


\subsection{3. Índice de solubilidade em água (ISA)}

O índice de solubilidade em água foi determinado conforme a metodologia descrita no item 3.4.3.

\subsubsection{Propriedades de pasta}

Foi determinada pelo equipamento Extrusion 1 do software Thermocline for Windows, versão 2.2, conforme a metodologia descrita no item 3.4.4.

\subsubsection{Propriedades térmicas}

As propriedades térmicas foram analisadas usando-se um calorímetro diferencial de varredura (DSC) Pyris 1 (Perkin Elmer, USA), segundo a metodologia descrita no item 3.4.5.

\subsubsection{Teor de amido resistente}

Foi determinado segundo a metodologia descrita no item 3.4.6.

\subsection{Análise estatística}

Para a análise estatística dos resultados experimentais foi utilizado o

modelo:

$$
\mathrm{y}_{\mathrm{k}}=\mathrm{b}_{0}+\sum_{i=1}^{4} \mathrm{~b}_{\mathrm{i}} \mathrm{x}_{\mathrm{ik}}+\sum_{i=1}^{4} \sum_{i=1}^{4} \mathrm{~b}_{\mathrm{ij}} \mathrm{x}_{\mathrm{ik}} \mathrm{x}_{\mathrm{jk}}+\mathrm{e}_{\mathrm{k}}
$$

onde:

$\mathrm{y}_{\mathrm{k}}=$ valor observado da variável dependente no nível $K, \mathrm{~K}=1, \ldots, 30$;

$\mathrm{x}_{\mathrm{iK}}=\mathrm{i}$-ésima variável independente, no nível $K, \mathrm{i}=1,2,3,4$;

$\mathrm{b}_{0}=$ parâmetro do modelo, independente de $\mathrm{x}$;

$b_{i}=$ parâmetros correspondentes aos efeitos lineares de $x_{i}$; 
$b_{i j}=$ parâmetros correspondentes aos efeitos de $2^{a}$ ordem de $x_{i} x_{j}, i=1,2,3,4 j=1, \ldots, 4$;

$\mathrm{e}_{\mathrm{k}}=$ erro experimental associado à k-ésima parcela.

O processamento dos dados e a análise estatística foram realizados com o auxílio do sistema SAS. A significância do modelo foi testada pela análise de variância (ANOVA), sendo adotado o nível de significância alfa de 5\%.

$\mathrm{Na}$ análise dos dados realizada pelo programa SAS, inicialmente foi feito à análise de variância sendo determinados os coeficientes de regressão do modelo incluindo todos os parâmetros (linear, quadrática e interação). O ajuste do modelo foi feito pela opção "step-wise", sendo que o modelo obtido foi validado pelo teste F utilizando-se como denominador o quadrado médio do erro puro.

Este procedimento foi adotado visto que alguns parâmetros do modelo apenas são significativos após a inclusão de outros, portanto, o modelo final ajustado pode incluir parâmetros não significativos, mas necessários.

$\mathrm{Na}$ construção das superfícies de resposta duas variáveis independentes variam dentro das regiões estudas e a terceira é mantida fixa no ponto central. 


\section{RESULTADOS E DISCUSSÃO}

\subsection{Caracterização das matérias-primas}

A composição química das matérias-primas está entre os principais fatores interferentes no desenvolvimento de produtos extrusados. Os resultados obtidos nas análises de caracterização das matérias-primas: fécula, farelo de mandioca e farinha de soja estão apresentados na Tabela 3. A fécula de mandioca apresentou baixas quantidades de componentes não amidos e o farelo, resíduo da extração da fécula, apresentou significativo teor de fibras justificando seu aproveitamento em produtos funcionais. A farinha de soja apresentou elevado teor protéico e também considerável teor de matéria-graxa e fibras.

Leonel et al., (2008) caracterizando o farelo de mandioca para uso na produção de biscoitos extrusados de polvilho azedo obtiveram $6,0 \%$ de umidade, $76,32 \%$ de amido; $9,9 \%$ de fibras; $0,92 \%$ de fibras; $5,3 \%$ de matéria-graxa; $1,3 \%$ de fibras e $0,3 \%$ de açúcares redutores. Estes resultados diferem dos obtidos neste experimento, principalmente quanto ao teor de fibras, o que pode ser reflexo de uma melhor extração do amido na empresa que cedeu o material. 
Tabela 3- Composição físico-química média da fécula, farelo de mandioca e farinha de soja.

\begin{tabular}{cccc}
\hline ANÁLISES & Fécula & Farelo & Farinha de soja \\
\hline g/100g & 13,8 & 6,4 & \\
Umidade & 0,07 & 1,57 & 7,2 \\
Cinzas & 0,39 & 21,37 & 0,79 \\
Fibras & 0,11 & 0,34 & 8,83 \\
Matéria Graxa & 0,44 & 2,58 & 21,33 \\
Proteínas & 85,19 & 67,74 & 46,75 \\
Carboidratos Totais & 1,36 & 12,17 & 15,1 \\
\hline Acidez Titulável & 5,38 & 5,19 & 3,20 \\
pH & & & 6,95 \\
\hline
\end{tabular}

Os dados obtidos para a farinha de soja integral encontraram-se próximos aos relatados por Silva et al., (2006) para grãos de soja que foram de 5,6\% de umidade, 40,4\% de proteína, $24,55 \%$ de lipídios, $17,26 \%$ de carboidratos, 9,31\% de fibras e $2,88 \%$ de cinzas. Segundo Horan (1974), a composição química da soja pode variar com as condições climáticas, tipo de solo, localização geográfica, variedades e práticas agronômicas, entre outros fatores.

\subsection{Caracterização das misturas}

Observou-se que o teor de fibras totais variou de 4,18 a $8,37 \%$, sendo o maior valor para aquelas misturas que apresentaram maiores proporções de farelo de mandioca (Tabela 4). Segundo a ANVISA (2009), um produto pronto para o consumo deve ter como atributo a proporção de $3 \mathrm{~g}$ de fibra $/ 100 \mathrm{~g}$, ou com alto teor de fibras, $6 \mathrm{~g}$ de fibras $/ 100 \mathrm{~g}$ para produtos sólidos.

A matéria graxa apresentou valores entre 2,28 a $6,52 \%$. Cerca de $7 \%$ da gordura existente na soja é composto pelo o ácido linolénico, uma gordura poliinsaturada que pode ajudar a diminuir o risco de enfarte do miocárdio, uma vez que inibe a formação de coágulos sanguíneos (MENDES, 2009).

A proteína variou de 12,55 a $5,5 \%$ o que é proporcional com o aumento do teor de soja nas misturas. HARPER (1979), enfatiza que a adição de ingredientes 
com alto teor de proteína tende a reduzir a expansão de uma mistura extrusada. Formulação contendo alta quantidade de proteína resulta em uma massa viscosa, necessitando de maior energia mecânica durante o processo e maior pressão na matriz.

Tabela 4- Composição química calculada das misturas de fécula, farelo de mandioca e farinha de soja.

\begin{tabular}{cccccccccc}
\hline \multicolumn{4}{c}{ Matérias-primas (\%) } & \multicolumn{7}{c}{ Composição (g/100g) } \\
\hline $\begin{array}{c}\text { Mistura } \\
\text { s }\end{array}$ & Fécula & Farelo & $\begin{array}{c}\text { Farinha } \\
\text { de soja }\end{array}$ & $\begin{array}{c}\text { Umidade } \\
(\%)\end{array}$ & Cinzas & Fibras & $\begin{array}{c}\text { Matéria } \\
\text { graxa }\end{array}$ & Proteína & $\begin{array}{c}\text { Carboidratos } \\
\text { totais }\end{array}$ \\
\hline 1 & 70 & 15 & 15 & 11,7 & 0,40 & 4,80 & 3,33 & 7,71 & 72,06 \\
2 & 60 & 25 & 15 & 11,0 & 0,55 & 6,90 & 3,35 & 7,92 & 70,32 \\
3 & 60 & 15 & 25 & 11,0 & 0,48 & 5,65 & 5,45 & 12,34 & 65,05 \\
4 & 50 & 25 & 25 & 10,3 & 0,62 & 7,75 & 5,47 & 12,55 & 63,32 \\
5 & 70 & 10 & 20 & 11,7 & 0,36 & 4,18 & 4,38 & 9,92 & 69,42 \\
6 & 50 & 30 & 20 & 9,4 & 0,66 & 8,37 & 5,34 & 10,34 & 65,94 \\
7 & 70 & 20 & 10 & 11,6 & 0,44 & 5,43 & 2,28 & 5,5 & 74,69 \\
8 & 50 & 20 & 30 & 10,3 & 0,59 & 7,12 & 6,52 & 14,76 & 60,68 \\
9 & 60 & 20 & 20 & 11,0 & 0,51 & 6,27 & 4,4 & 10,13 & 67,68 \\
\hline
\end{tabular}

A variação observada para os carboidratos totais nos diferentes tratamentos foi de 63,32 a $74,69 \%$ evidenciando que as mistura com maiores proporções de fécula de mandioca apresentaram os maiores valores.

\subsubsection{Cor}

A análise dos dados mostrou terem ocorrido diferenças significativas entre as misturas para os parâmetros de cor (Tabela 5). A luminosidade variou entre as misturas, sendo que, as menores proporções de farelo de mandioca na mistura promoveram maior luminosidade ( $\left.\mathrm{L}^{*}\right)$, o que é comprovado pela baixa luminosidade da mistura 6 , que utilizou a maior porcentagem dessa matéria-prima. 
Quanto ao croma $a^{*}$, o maior valor é observado na mistura 6, que possui maior teor de farelo de mandioca e o menor valor na mistura 5 , que utilizou a menor quantidade deste resíduo, o que comprova a interferência desta na cor das misturas.

Para o croma b*, nota-se que, a presença deste croma é obtida pela influência da farinha de soja, sendo evidenciada pelos dados obtidos para as misturas 8 e 9 , com maior quantidade e menor quantidade, respectivamente.

Tabela 5- Porcentagem de matéria-prima e luminosidade $\mathrm{L}^{*}$, croma $\mathrm{a}^{*}$ e croma $\mathrm{b}^{*}$ das misturas.

\begin{tabular}{ccccccc}
\hline \multicolumn{3}{c}{ Matérias-primas } & \multicolumn{3}{c}{ Características } \\
\hline Misturas & $\begin{array}{c}\text { Fécula } \\
(\%)\end{array}$ & $\begin{array}{c}\text { Farelo de } \\
\text { mandioca } \\
(\%)\end{array}$ & $\begin{array}{c}\text { Farinha } \\
\text { de soja } \\
(\%)\end{array}$ & $\mathrm{L}^{*}$ & $\mathrm{a}^{*}$ & $\mathrm{~b}^{*}$ \\
\hline 1 & 70 & 15 & 15 & $90,8 \mathrm{ab}$ & $0,24 \mathrm{~d}$ & $9,7 \mathrm{e}$ \\
2 & 60 & 25 & 15 & $89,1 \mathrm{de}$ & $0,68 \mathrm{~b}$ & $10,53 \mathrm{~d}$ \\
3 & 60 & 15 & 25 & $89,9 \mathrm{~cd}$ & $0,14 \mathrm{de}$ & $11,6 \mathrm{bc}$ \\
4 & 50 & 25 & 25 & $88,1 \mathrm{gh}$ & $0,63 \mathrm{bc}$ & $12,03 \mathrm{ab}$ \\
5 & 70 & 10 & 20 & $91,0 \mathrm{a}$ & $0,03 \mathrm{e}$ & $11,01 \mathrm{~cd}$ \\
6 & 50 & 30 & 20 & $87,5 \mathrm{~h}$ & $0,89 \mathrm{a}$ & $11,67 \mathrm{bc}$ \\
7 & 70 & 20 & 10 & $90,1 \mathrm{bc}$ & $0,65 \mathrm{bc}$ & $9,39 \mathrm{e}$ \\
8 & 50 & 20 & 30 & $88,2 \mathrm{fgh}$ & $0,49 \mathrm{c}$ & $12,6 \mathrm{a}$ \\
9 & 60 & 20 & 20 & $88,5 \mathrm{efg}$ & $0,70 \mathrm{~b}$ & $11,52 \mathrm{bc}$ \\
\hline
\end{tabular}

*Médias seguidas de mesma letra na coluna não diferem entre si ao nível de 5\% de significância pelo teste de Tukey.

\subsection{2. Índices de absorção de água (IAA) e solubilidade em água (ISA)}

Com relação aos resultados obtidos para os índices de absorção e solubilidade em água das misturas, foram observadas diferenças significativas entre as misturas (Tabela 6).

O índice de solubilidade (ISA) em água é um parâmetro que mede o grau de degradação total do grânulo de amido, e esse indicador variou de 2,78 a 6,81\%. O maior valor de ISA foi obtido com $30 \%$ de farinha de soja na mistura, o que se deve provavelmente ao grande teor de proteína presente nessa mistura. 
Tabela 6- Médias e análise estatística do índice de absorção de água (IAA) e índice de solubilidade (ISA) das misturas de fécula, farelo de mandioca e farinha de soja.

\begin{tabular}{cccccc}
\hline \multirow{5}{*}{ Misturas } & \multicolumn{5}{c}{ Matérias-primas } \\
\cline { 2 - 4 } & $\begin{array}{c}\text { Fécula } \\
(\%)\end{array}$ & $\begin{array}{c}\text { Farelo de } \\
\text { mandioca }(\%)\end{array}$ & $\begin{array}{c}\text { Farinha de soja } \\
(\%)\end{array}$ & $\begin{array}{c}\text { IAA } \\
(\mathrm{g} \text { gel } / \mathrm{g})\end{array}$ & ISA (\%) \\
\hline 1 & 70 & 15 & 15 & $2,40 \mathrm{e}$ & $4,05 \mathrm{e}$ \\
2 & 60 & 25 & 15 & $2,65 \mathrm{c}$ & $4,01 \mathrm{e}$ \\
3 & 60 & 15 & 25 & $2,68 \mathrm{c}$ & $6,4 \mathrm{~b}$ \\
4 & 50 & 25 & 25 & $2,92 \mathrm{a}$ & $6,43 \mathrm{~b}$ \\
5 & 70 & 10 & 20 & $2,35 \mathrm{e}$ & $5,28 \mathrm{c}$ \\
6 & 50 & 30 & 20 & $2,78 \mathrm{~b}$ & $5,10 \mathrm{~cd}$ \\
7 & 70 & 20 & 10 & $2,39 \mathrm{e}$ & $2,78 \mathrm{f}$ \\
8 & 50 & 20 & 30 & $2,76 \mathrm{~b}$ & $6,81 \mathrm{a}$ \\
9 & 60 & 20 & 20 & $2,53 \mathrm{~d}$ & $4,97 \mathrm{~d}$ \\
\hline
\end{tabular}

*Médias seguidas de mesma letra na coluna não diferem entre si ao nível de 5\% de significância pelo teste de Tukey.

O índice de absorção de água (IAA) está relacionado com a disponibilidade de grupos hidrofílicos $(-\mathrm{OH})$ em se ligar às moléculas de água e a capacidade de formação de gel das moléculas de amido. Os índices de absorção de água das misturas variaram de $2,92 \mathrm{gel} / \mathrm{g}$ a $2,35 \mathrm{~g}$ gel $/ \mathrm{g}$, nas misturas 4 e 5 , respectivamente, com o menor valor observado na mistura com maior porcentagem de fécula.

\subsubsection{Propriedades de pasta}

A viscosidade é uma das propriedades mais importantes em misturas farináceas. A curva de viscosidade representa o comportamento durante o aquecimento e permite avaliar as características da pasta formada, devido às modificações estruturais das moléculas de amido, e de outros componentes e, também, à tendência a retrogradação durante o resfriamento. Essas características determinam as propriedades funcionais das matériasprimas amiláceas e suas diversas aplicações industriais.

A viscosidade inicial (VI) a $25^{\circ} \mathrm{C}$, também chamada de viscosidade de 
pasta a frio, indica a capacidade das farinhas absorverem água a temperatura ambiente e formar uma pasta, gel ou líquido viscoso. Os resultados obtidos para as propriedades de pasta das matérias-primas (Tabela 7) mostraram que a farinha de soja apresentou a maior viscosidade inicial (VI). A fécula mostrou os maiores valores de pico de viscosidade (PV), quebra (QV), viscosidade final (VF) e tendência a retrogradação (TR), o que indica à presença de grânulos intactos e baixa resistência à elevada temperatura e agitação. O farelo, quando comparado com a fécula, mostrou menores valores de propriedades de pasta, o que pode ser devido à presença de fibras.

Tabela 7- Propriedades de pasta da fécula, farelo de mandioca, farinha de soja e suas misturas.

\begin{tabular}{cccccc}
\hline $\begin{array}{c}\text { Matéria-prima } \\
e\end{array}$ & $\begin{array}{c}\text { Viscosidade } \\
\text { Inicial } \\
(\text { RVU })\end{array}$ & $\begin{array}{c}\text { Pico de } \\
\text { Viscosida } \\
\text { de } \\
(R V U)\end{array}$ & $\begin{array}{c}\text { Quebrade } \\
\text { Viscosidade } \\
(\text { RVU })\end{array}$ & $\begin{array}{c}\text { Viscosidade } \\
\text { Final } \\
(\text { RVU })\end{array}$ & $\begin{array}{c}\text { Tendência a } \\
\text { Retrogradação } \\
(\text { RVU })\end{array}$ \\
\hline Fécula & 0,00 & 421,42 & 223,00 & 299,17 & 100,75 \\
Farelo & 0,00 & 125,67 & 17,09 & 163,08 & 54,50 \\
Soja & 22,00 & 5,17 & 3,67 & 2,17 & 0,67 \\
Mistura 1 & 2,67 & 234,32 & 105,90 & 297,58 & 169,16 \\
Mistura 2 & 4,83 & 200,67 & 85,59 & 274,58 & 159,50 \\
Mistura 3 & 2,92 & 158,58 & 56,91 & 231,50 & 129,83 \\
Mistura 4 & 3,17 & 135,67 & 48,84 & 210,50 & 123,67 \\
Mistura 5 & 1,42 & 210,83 & 86,58 & 281,42 & 157,17 \\
Mistura 6 & 3,00 & 153,33 & 57,00 & 222,08 & 125,75 \\
Mistura 7 & 2,25 & 263,50 & 121,75 & 243,00 & 101,25 \\
Mistura 8 & 4,58 & 116,08 & 32,25 & 194,56 & 110,73 \\
Mistura 9 & 4,17 & 176,58 & 66,58 & 243,00 & 133,00 \\
\hline
\end{tabular}

Nas misturas, observou-se que a maior porcentagem de farinha de soja (mistura 8) influenciou nas propriedades de pasta, as quais foram muito superiores a aquelas observadas nas demais misturas. Mantendo a quantidade de farinha de soja e variando a porcentagem de farelo de mandioca em seus extremos (mistura 5 e mistura 6), observou-se um aumento da VI e redução das demais propriedades, evidenciando a interferência das fibras. 
Maia et al., (1999), analisando a viscosidade de pasta em viscógrafo Brabender de mingaus desidratados de arroz e soja, observaram que com o aumento das proporções de soja (0 a 50\%) houve um aumento na temperatura de viscosidade máxima e uma diminuição na viscosidade máxima, resultado também por Borges et al., (1998) em misturas de canjiquinha e soja.

Segundo Silveira et al., (1981), o aumento da soja nas misturas de farinhas de arroz e soja diminui o teor de amido e, com isso, a viscosidade. Outro fator importante é a diminuição da água disponível para a gelatinização do amido por sua interação com a proteína.

\subsubsection{Propriedades térmicas}

O amido quando aquecido em excesso de água sofre uma transição de segunda ordem, irreversível, denominada gelatinização, que corresponde ao rompimento, expansão e hidratação da estrutura granular e ainda solubilização das macromoléculas constituintes do amido.

A análise dos dados mostrou ter ocorrido diferença significativa para a temperatura de pico e entalpia de gelatinização entre as misturas 5 e 8 (Tabela 8). Estes resultados evidenciam a interferência das quantidades de amido nas misturas.

Os valores observados para a temperatura inicial $\left(60,81\right.$ a $\left.59,30^{\circ} \mathrm{C}\right)$, temperatura de pico $\left(67,9\right.$ a $\left.67,23^{\circ} \mathrm{C}\right)$ e temperatura final $\left(74,36\right.$ a $\left.73,56^{\circ} \mathrm{C}\right)$ foram muito próximos aos encontrados por Lustosa et al., (2009) para farinha de mandioca $(64,26,68,08 \mathrm{e}$ $72,82^{\circ} \mathrm{C}$ para $\mathrm{Ti}, \mathrm{Tp}$ e $\mathrm{Tf}$, respectivamente), tendo uma diferença um pouco maior a temperatura inicial. 
Tabela 8- Propriedades térmicas das misturas de farinha de soja, fécula e farelo de mandioca antes do processo de extrusão.

\begin{tabular}{|c|c|c|c|c|c|c|c|}
\hline \multirow[b]{2}{*}{ Misturas } & \multicolumn{3}{|c|}{ Matérias-primas } & \multicolumn{3}{|c|}{$\begin{array}{l}\text { Temperatura de gelatinização } \\
\qquad\left({ }^{\circ} \mathrm{C}\right)\end{array}$} & \multirow[b]{2}{*}{$\Delta \mathrm{H}(\mathrm{J} / \mathrm{g})$} \\
\hline & $\begin{array}{l}\text { Fécula } \\
(\%)\end{array}$ & $\begin{array}{c}\text { Farelo de } \\
\text { mandioca } \\
(\%)\end{array}$ & $\begin{array}{c}\text { Farinha } \\
\text { de soja } \\
(\%)\end{array}$ & $\mathrm{Ti}$ & $\mathrm{Tp}$ & $\mathrm{Tf}$ & \\
\hline 1 & 70 & 15 & 15 & $59,58 \mathrm{a}$ & $67,53 \mathrm{ab}$ & $74,03 a$ & $8,60 \mathrm{ab}$ \\
\hline 2 & 60 & 25 & 15 & $59,60 \mathrm{a}$ & $67,27 \mathrm{ab}$ & $73,56 a$ & $8,20 \mathrm{abc}$ \\
\hline 3 & 60 & 15 & 25 & $59,95 \mathrm{a}$ & $67,57 \mathrm{ab}$ & $74,00 \mathrm{a}$ & $7,78 \mathrm{abc}$ \\
\hline 4 & 50 & 25 & 25 & $60,81 \mathrm{a}$ & $67,69 \mathrm{ab}$ & $73,91 \mathrm{a}$ & $7,12 b c$ \\
\hline 5 & 70 & 10 & 20 & $59,30 \mathrm{a}$ & $67,23 b$ & $73,85 \mathrm{a}$ & $9,05 \mathrm{a}$ \\
\hline 6 & 50 & 30 & 20 & $60,02 \mathrm{a}$ & $67,66 \mathrm{ab}$ & $73,93 a$ & $7,28 \mathrm{bc}$ \\
\hline 7 & 70 & 20 & 10 & $59,95 \mathrm{a}$ & $67,41 \mathrm{ab}$ & $73,84 \mathrm{a}$ & $8,98 \mathrm{a}$ \\
\hline 8 & 50 & 20 & 30 & $60,46 a$ & $67,91 \mathrm{a}$ & $74,36 \mathrm{a}$ & $6,95 c$ \\
\hline 9 & 60 & 20 & 20 & $59,94 \mathrm{a}$ & $67,68 \mathrm{ab}$ & $73,99 \mathrm{a}$ & $8,23 \mathrm{abc}$ \\
\hline
\end{tabular}

*Médias seguidas de mesma letra na coluna não diferem entre si ao nível de 5\% pelo teste de Tukey. Ti= temperatura inicial; $\mathrm{Tp}=$ temperatura de pico; $\mathrm{Tf}=$ temperatura final; $\Delta \mathrm{H}=$ variação de entalpia.

A entalpia de gelatinização das misturas $(9,05$ a $6,9 \mathrm{~J} / \mathrm{g})$ foi inferior à relatada por Lustosa et al., (2009) para farinha de mandioca $(9,79 \mathrm{~J} / \mathrm{g})$ e também a aquela encontrada por Jane et al., (1999) para amido nativo de mandioca $(14,7 \mathrm{~J} / \mathrm{g})$, o que pode ser devido à presença de proteína e os demais componentes das misturas.

\subsubsection{Amido resistente nas misturas}

O amido é o componente mais abundante da maioria dos alimentos sendo responsável pelas propriedades tecnológicas que caracterizam grande parte dos produtos processados. De acordo com a velocidade com a qual o alimento é digerido in vitro, o amido divide-se em: rapidamente digerível, lentamente digerível e amido resistente (AR) que resiste à ação das enzimas digestivas (ENGLYST \& KINGMAN, 1992).

Os resultados obtidos mostraram uma variação de a 1,23 a $2,65 \%$ no teor de amido resistente nas misturas (Tabela 9). 
Tabela 9- Médias dos teores de amido resistente nas misturas antes da extrusão.

\begin{tabular}{ccccc}
\hline Misturas & $\begin{array}{c}\text { Fécula } \\
(\%)\end{array}$ & $\begin{array}{c}\text { Farelo } \\
(\%)\end{array}$ & $\begin{array}{c}\text { Farinha de soja } \\
(\%)\end{array}$ & $\begin{array}{c}\text { AR } \\
(\%)\end{array}$ \\
\hline 1 & 70 & 15 & 15 & $1,87 \mathrm{~d}$ \\
2 & 60 & 25 & 15 & $2,48 \mathrm{~b}$ \\
3 & 60 & 15 & 25 & $2,65 \mathrm{a}$ \\
4 & 50 & 25 & 25 & $1,73 \mathrm{e}$ \\
5 & 70 & 10 & 20 & $2,37 \mathrm{c}$ \\
6 & 50 & 30 & 20 & $2,34 \mathrm{c}$ \\
7 & 70 & 20 & 10 & $1,75 \mathrm{e}$ \\
8 & 50 & 20 & 30 & $1,23 \mathrm{f}$ \\
9 & 60 & 20 & 20 & $1,74 \mathrm{e}$ \\
\hline
\end{tabular}

*Médias seguidas de mesma letra na coluna não diferem entre si ao nível de 5\% pelo teste de Tukey.

Os resultados obtidos para amido resistente (AR) nas misturas diferem dos observados por Freitas e Leonel (2008) para fécula de mandioca que foi de 4,15\%, o que pode ser devido a menor porcentagem de amido nas misturas, o que é evidenciado na mistura 8 que contém a maior porcentagem de farinha de soja e o menor teor de AR.

\subsection{Caracterização dos produtos extrusados expandidos}

\subsubsection{Volume específico (VE)}

O volume específico é uma medida da expansão volumétrica, que é a soma das expansões radial e axial. Os valores observados para o volume específico dos produtos extrusados nas diferentes condições experimentais variaram de a 2,64 a 7,75 ml.g $\mathrm{g}^{-1}$ (Tabela 10). A análise dos dados mostrou efeito quadrático da temperatura de extrusão, bem como, da interação da porcentagem de farinha de soja na mistura e rotação da rosca, sobre este parâmetro (Tabela 11). 
Tabela 10- Resultados do índice de expansão e volume específico dos extrusados.

\begin{tabular}{|c|c|c|c|c|c|c|c|c|c|c|}
\hline \multirow[b]{2}{*}{ Tratamentos } & \multicolumn{4}{|c|}{$\begin{array}{c}\text { Níveis } \\
\text { codificados }\end{array}$} & \multicolumn{4}{|c|}{$\begin{array}{c}\text { Variáveis } \\
\text { independentes }\end{array}$} & \multicolumn{2}{|c|}{$\begin{array}{c}\text { Variáveis } \\
\text { dependentes }\end{array}$} \\
\hline & X1 & $\mathrm{X} 2$ & X3 & X4 & FM & FS & $\mathbf{T}$ & $\mathbf{R}$ & IE & VE \\
\hline 1 & -1 & -1 & -1 & -1 & 15 & 15 & 60 & 210 & 2,38 & 5,43 \\
\hline 2 & 1 & -1 & -1 & -1 & 25 & 15 & 60 & 210 & 2,49 & 5,40 \\
\hline 3 & -1 & 1 & -1 & -1 & 15 & 25 & 60 & 210 & 2,54 & 6,58 \\
\hline 4 & 1 & 1 & -1 & -1 & 25 & 25 & 60 & 210 & 2,47 & 5,03 \\
\hline 5 & -1 & -1 & 1 & -1 & 15 & 15 & 90 & 210 & 2,23 & 5,88 \\
\hline 6 & 1 & -1 & 1 & -1 & 25 & 15 & 90 & 210 & 2,50 & 5,39 \\
\hline 7 & -1 & 1 & 1 & -1 & 15 & 25 & 90 & 210 & 2,26 & 5,56 \\
\hline 8 & 1 & 1 & 1 & -1 & 25 & 25 & 90 & 210 & 2,43 & 7,15 \\
\hline 9 & -1 & -1 & -1 & 1 & 15 & 15 & 60 & 250 & 2,26 & 5,69 \\
\hline 10 & 1 & -1 & -1 & 1 & 25 & 15 & 60 & 250 & 2,27 & 6,55 \\
\hline 11 & -1 & 1 & -1 & 1 & 15 & 25 & 60 & 250 & 2,19 & 5,89 \\
\hline 12 & 1 & 1 & -1 & 1 & 25 & 25 & 60 & 250 & 2,41 & 6,08 \\
\hline 13 & -1 & -1 & 1 & 1 & 15 & 15 & 90 & 250 & 2,56 & 7,19 \\
\hline 14 & 1 & -1 & 1 & 1 & 25 & 15 & 90 & 250 & 2,33 & 6,81 \\
\hline 15 & -1 & 1 & 1 & 1 & 15 & 25 & 90 & 250 & 2,16 & 4,66 \\
\hline 16 & 1 & 1 & 1 & 1 & 25 & 25 & 90 & 250 & 2,24 & 5,80 \\
\hline 17 & -2 & 0 & 0 & 0 & 10 & 20 & 75 & 230 & 2,15 & 2,64 \\
\hline 18 & 2 & 0 & 0 & 0 & 30 & 20 & 75 & 230 & 2,43 & 4,42 \\
\hline 19 & 0 & -2 & 0 & 0 & 20 & 10 & 75 & 230 & 2,15 & 3,61 \\
\hline 20 & 0 & 2 & 0 & 0 & 20 & 30 & 75 & 230 & 2,29 & 3,50 \\
\hline 21 & 0 & 0 & -2 & 0 & 20 & 20 & 45 & 230 & 2,24 & 6,18 \\
\hline 22 & 0 & 0 & 2 & 0 & 20 & 20 & 105 & 230 & 2,28 & 7,75 \\
\hline 23 & 0 & 0 & 0 & -2 & 20 & 20 & 75 & 190 & 2,18 & 2,98 \\
\hline 24 & 0 & 0 & 0 & 2 & 20 & 20 & 75 & 270 & 2,12 & 4,44 \\
\hline 25 & 0 & 0 & 0 & 0 & 20 & 20 & 75 & 230 & 2,12 & 3,85 \\
\hline
\end{tabular}

X1: farelo de mandioca (\%); X2: farinha de soja (\%); X3: temperatura na $3^{\mathrm{a}}$ zona do extrusor $\left({ }^{\circ} \mathrm{C}\right)$; X4: rotação da rosca (rpm); IE: índice de expansão; VE: volume específico $\left(\mathrm{mL} . \mathrm{g}^{-1}\right)$.

A Figura 1 mostra que de acordo com o modelo ajustado nas condições intermediárias de temperatura o volume específico é menor. Souza et al., (2007), avaliando o efeito das condições de extrusão em produtos expandidos produzidos a partir de misturas de fécula de mandioca e polpa cítrica, observaram que o volume específico dos extrusados decresceu com o aumento da temperatura e umidade, variando de a 1,71 a $8,54 \mathrm{ml} . \mathrm{g}^{-1}$. 
Tabela 11- Coeficientes de regressão estimados e ANOVA para o volume específico dos produtos.

\begin{tabular}{lcccc}
\hline & $\begin{array}{c}\text { Coeficientes de } \\
\text { regressão }\end{array}$ & Erro padrão & GL & P valor \\
\hline Média & 4,39472 & 0,23248 & & \\
Temperatura (Q) & 0,98701 & 0,18379 & 1 & $<0,0001$ \\
Farinha de soja x rotação & $-0,49813$ & 0,24659 & 1 & 0,0534 \\
$\mathrm{R}^{2}$ & 0,5494 & & & \\
\hline
\end{tabular}

\begin{tabular}{lcccccc}
\hline ANOVA & & & & & \\
& GL & SQ & QM & F calculado & $F_{\text {tabelado }}$ & Pr>F \\
\hline Regressão & 2 & 32,02691 & 16,01346 & 16,46 & 3,35 & $<0,0001$ \\
Resíduos & 27 & 26,26742 & 0,97287 & & & \\
Total & 29 & 58,29434 & & & & \\
\hline
\end{tabular}

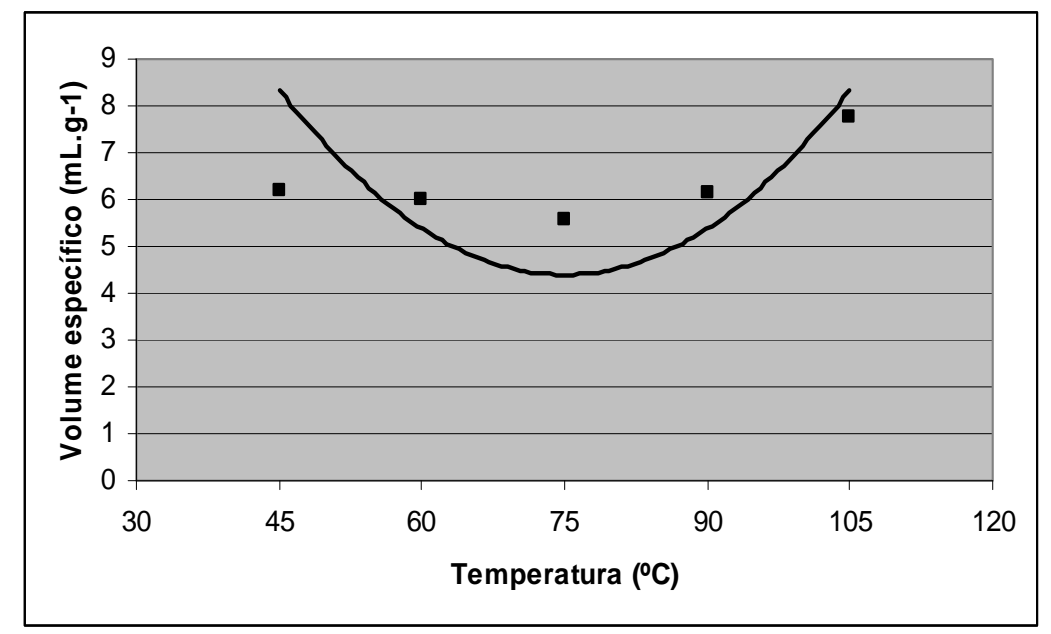

Figura 1- Efeito da temperatura de extrusão sobre o volume específico dos extrusados, com as porcentagens de farelo de mandioca e farinha de soja em $20 \%$ e rotação de $230 \mathrm{rpm}$.

Alves \& Grossmann (2002) observaram que nas condições de $16 \%$ de umidade, temperatura de $170^{\circ} \mathrm{C}$ e diâmetro de matriz de $3 \mathrm{~mm}$ obteve-se o maior volume 
específico $(6,32 \mathrm{ml} / \mathrm{g})$ em snacks de farinha de cará, inferior ao valor médio de snacks comerciais de milho $(8,72 \mathrm{ml} / \mathrm{g})$.

Os biscoitos de polvilho, produtos expandidos após escaldamento e forneamento, são classificados pelo volume específico como: produtos de baixo VE, quando este é menor que 5,0ml/g, médio volume específico (VE) de 5,0 a 10,0 ml/g, e grande VE, quando maior que 10,0ml/g (NUNES, 1999). Com base nesta classificação os produtos extrusados, poderiam ser classificados como produtos de médio e baixo VE.

De acordo com DING et al., (2005), a água tem efeito inverso sobre a expansão, agindo como um plastificante para materiais amiláceos, reduzindo sua viscosidade e a dissipação de energia mecânica no extrusor e, assim, o produto fica mais denso e o crescimento das bolhas é comprimido.

O volume específico é um parâmetro primário, associado às medidas de fraturabilidade, dureza, absorção de água e solubilidade em água dos produtos por extrusão termoplástica. Está diretamente relacionado com a expansão e negativamente correlacionado com a densidade (KARAM et al., 2001).

A adição de fibra em snacks extrusados tem sido limitada a poucas fontes como o trigo e a aveia, fibra de beterraba açucarada e fibra de soja. Aumentos no mecanismo de energia associado com o aumento de fibra não são traduzidos em expansão grandiosa ou redução na densidade do volume específico, os quais são características desejáveis para snacks (ONWULATA et al., 2001).

\subsection{2. Índice de expansão (IE)}

Uma propriedade dos produtos extrusados é a expansão. A alta pressão existente próxima à descarga da matriz é reduzida quando o produto sai do extrusor, ocasionando a evaporação instantânea da água e a expansão do produto (BORBA et al., 2005). Os resultados obtidos para o índice de expansão dos extrusados variou de 2,12 a 2,56 nos diferentes tratamentos (Tabela 10). A análise dos coeficientes de regressão mostrou terem ocorrido efeitos quadráticos de todas as variáveis independentes e, também, das interações 
porcentagem de farinha de soja com rotação da rosca e temperatura de extrusão com rotação, sobre este parâmetro de expansão (Tabela 12).

Tabela 12 - Coeficientes de regressão estimados e ANOVA para o índice de expansão dos produtos.

\section{Coeficientes de $\quad$ Erro padrão $\quad$ GL $\quad P$ valor regressão}

\begin{tabular}{lcccc}
\hline Média & 2,08833 & & & \\
Farelo de mandioca (Q) & 0,04458 & 0,01943 & 1 & 0,0312 \\
Farinha de soja (Q) & 0,06833 & 0,01943 & 1 & 0,0018 \\
Temperatura (Q) & 0,06208 & 0,01943 & 1 & 0,0040 \\
Rotação (Q) & 0,05333 & 0,01943 & 1 & 0,0115 \\
Farinha de soja x rotação & $-0,07625$ & 0,02544 & 1 & 0,0064 \\
Temperatura x rotação & 0,06500 & 0,02544 & 1 & 0,0177 \\
$\mathrm{R}^{2}$ & 0,6389 & & & \\
\hline ANOA & & & &
\end{tabular}

\begin{tabular}{lcccccc}
\hline ANOVA & & & & & \\
& GL & SQ & QM & F calculado & $F_{\text {tabelado }}$ & Pr>F \\
\hline Regressão & 6 & 0,42118 & 0,07020 & 6,78 & 2,53 & 0,0003 \\
Resíduos & 23 & 0,23809 & 0,01035 & & & \\
Total & 29 & 0,65927 & & & & \\
\hline
\end{tabular}

Observou-se que nas condições extremas opostas de farinha de soja e rotação, bem como, nas condições de baixa rotação e temperatura e nos seus inversos foram obtidos os maiores índices de expansão (Figuras 2 e 3). 


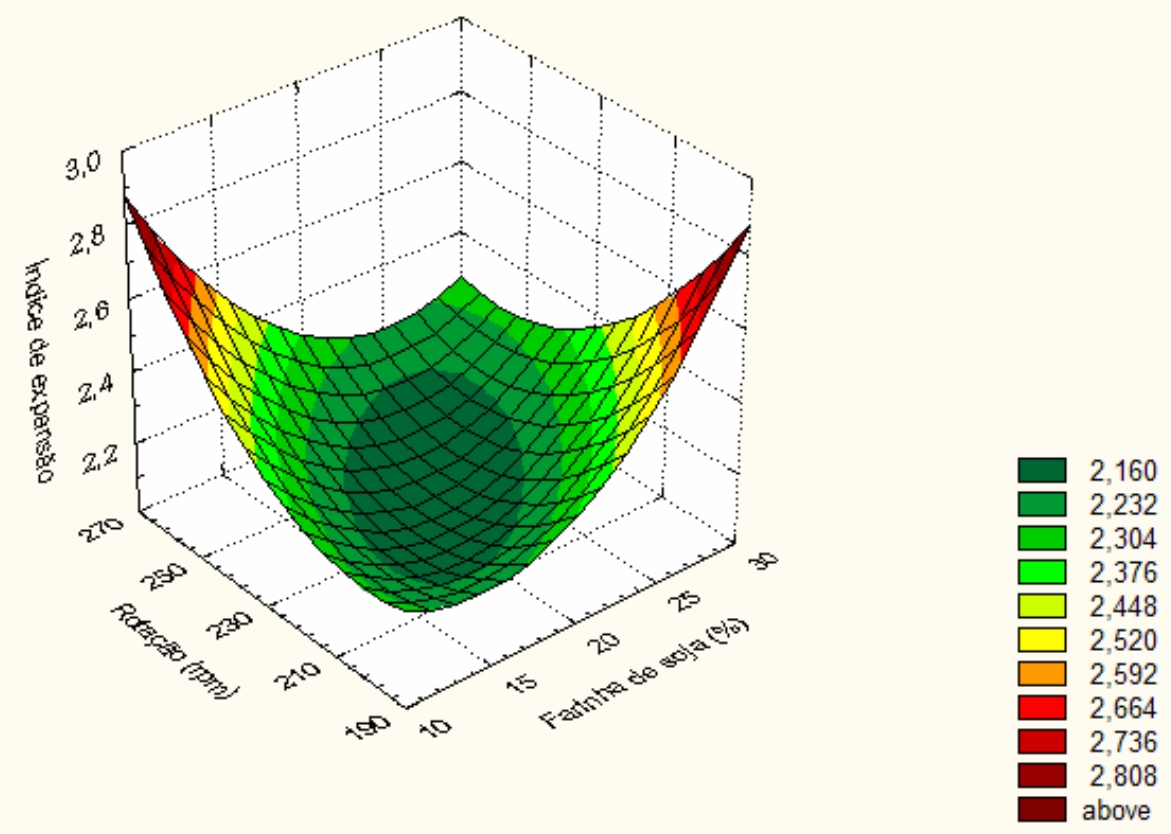

Figura 2- Efeito da porcentagem de farinha de soja e da rotação da rosca sobre o índice de expansão dos extrusados, com a temperatura em $75^{\circ} \mathrm{C}$.

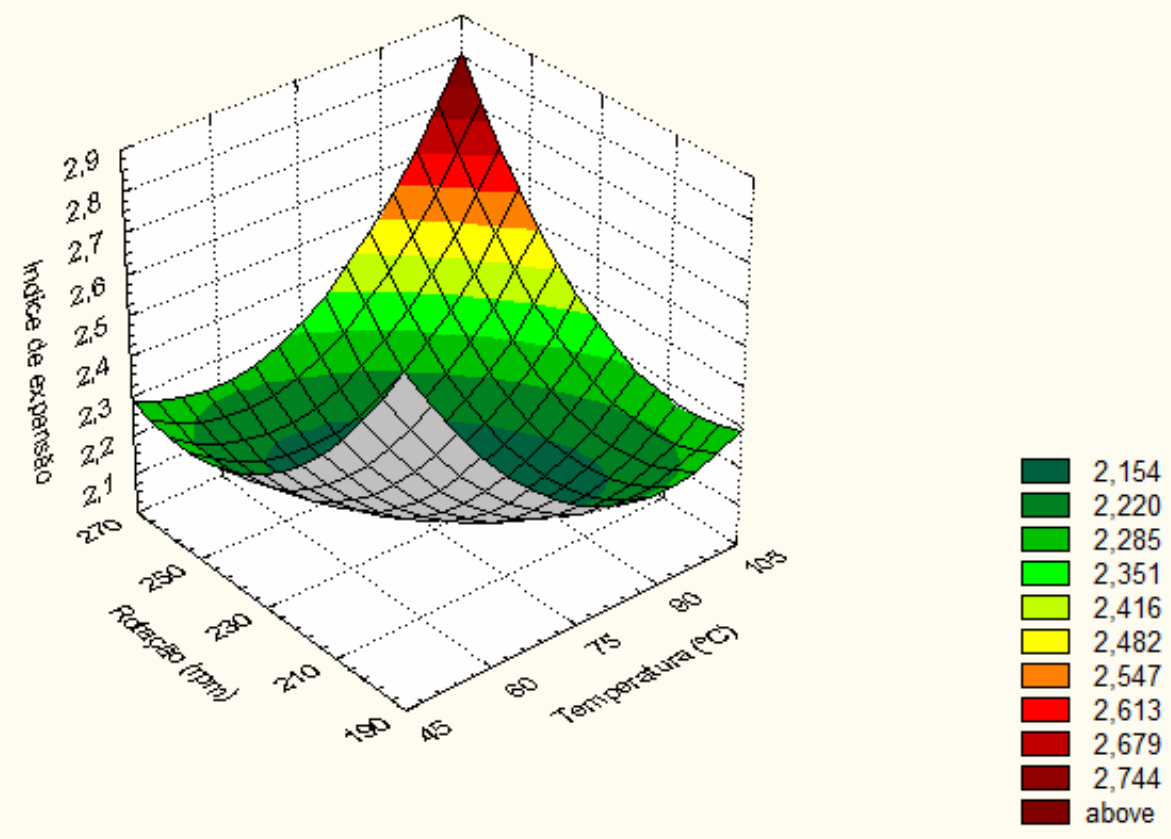

Figura 3- Efeito da temperatura de extrusão e rotação da rosca sobre o índice de expansão dos extrusados, com porcentagens de farinha de soja e farelo de mandioca $20 \%$. 
Berglund et al.; (1994), avaliando extrusados de cevada contendo altos teores de fibras, a expansão dos mesmos foi inibida, resultando em aumento na densidade. Com um aumento no conteúdo de fibra alimentar, os autores apontaram que ocorreu uma redução no teor de amido, interferindo na expansão do produto. Além disso, a redução na expansão deveu-se ao aumento nas quantidades de fibra alimentar, umidade e temperatura. A presença de fibras proporciona o rompimento das paredes das células e previne que as bolhas de gás expandam até o seu potencial máximo.

Chang \& El-Dash (2003) observaram o efeito da umidade (16 a 24\%) e da temperatura $\left(120\right.$ a $\left.200{ }^{\circ} \mathrm{C}\right)$ na expansão de produtos extrusados de fécula de mandioca. Com o aumento da temperatura de extrusão, sob baixa umidade e rotação de $100 \mathrm{rpm}$, os produtos apresentaram elevado índice de expansão.

Hashimoto \& Grossmann (2003), analisando o efeito das condições de extrusão sobre a qualidade de extrusados de misturas de farelo e amido de mandioca, obtiveram índice de expansão variando entre 1,6 e 3,2 e observaram a influência da porcentagem de fibras na expansão dos produtos. Resultados esses inferiores aos observados nesse trabalho.

\subsection{Análise das farinhas instantâneas}

\subsubsection{Cor}

A cor é uma qualidade visual (atributo) importante dos produtos alimentícios. Existem muitas reações que ocorrem durante a extrusão que afetam a cor. Dentre elas, as mais comuns são as reações de escurecimento não-enzimático (reação de Maillard e caramelização) e a degradação de pigmentos. As condições de processamento utilizadas na extrusão (alta temperatura e baixa umidade) são reconhecidas por favorecer a reação entre açúcares redutores e aminoácidos, o que resulta na formação de compostos coloridos e na redução do aminoácido lisina. Se o escurecimento é muito intenso, cores e sabores indesejáveis podem aparecer. Também, mudanças de cor durante o processo de extrusão 
podem ser um indicador para avaliar a intensidade do processo em relação às mudanças químicas e nutricionais (ILO \& BERGHOFER, 1999).

Os resultados obtidos para a análise de cor das misturas de farinha de soja, farelo, e fécula de mandioca após a extrusão estão apresentados na Tabela 13.

Tabela 13- Parâmetros de cor das farinhas extrusadas nas diferentes condições experimentais.

\begin{tabular}{|c|c|c|c|c|c|c|c|c|c|c|c|}
\hline \multirow[b]{2}{*}{ Trat. } & \multicolumn{4}{|c|}{$\begin{array}{c}\text { Níveis } \\
\text { codificados }\end{array}$} & \multicolumn{4}{|c|}{$\begin{array}{c}\text { Variáveis } \\
\text { independentes }\end{array}$} & \multicolumn{3}{|c|}{$\begin{array}{c}\text { Variáveis } \\
\text { dependentes }\end{array}$} \\
\hline & $\mathrm{X} 1$ & $\mathrm{X} 2$ & X3 & $\mathrm{X} 4$ & FM & FS & $\mathrm{T}$ & $\mathrm{R}$ & $\mathrm{L}^{*}$ & $\mathrm{a}^{*}$ & $b^{*}$ \\
\hline 1 & -1 & -1 & -1 & -1 & 15 & 15 & 60 & 210 & 72,31 & 3,76 & 21,83 \\
\hline 2 & 1 & -1 & -1 & -1 & 25 & 15 & 60 & 210 & 71,08 & 4,79 & 24,58 \\
\hline 3 & -1 & 1 & -1 & -1 & 15 & 25 & 60 & 210 & 73,50 & 3,80 & 22,59 \\
\hline 4 & 1 & 1 & -1 & -1 & 25 & 25 & 60 & 210 & 71,26 & 4,79 & 23,65 \\
\hline 5 & -1 & -1 & 1 & -1 & 15 & 15 & 90 & 210 & 75,25 & 3,86 & 21,00 \\
\hline 6 & 1 & -1 & 1 & -1 & 25 & 15 & 90 & 210 & 71,02 & 5,14 & 23,01 \\
\hline 7 & -1 & 1 & 1 & -1 & 15 & 25 & 90 & 210 & 77,15 & 3,54 & 20,81 \\
\hline 8 & 1 & 1 & 1 & -1 & 25 & 25 & 90 & 210 & 71,20 & 5,04 & 22,84 \\
\hline 9 & -1 & -1 & -1 & 1 & 15 & 15 & 60 & 250 & 68,06 & 5,15 & 23,04 \\
\hline 10 & 1 & -1 & -1 & 1 & 25 & 15 & 60 & 250 & 67,77 & 5,13 & 23,14 \\
\hline 11 & -1 & 1 & -1 & 1 & 15 & 25 & 60 & 250 & 70,59 & 5,03 & 24,58 \\
\hline 12 & 1 & 1 & -1 & 1 & 25 & 25 & 60 & 250 & 64,11 & 5,22 & 22,00 \\
\hline 13 & -1 & -1 & 1 & 1 & 15 & 15 & 90 & 250 & 74,91 & 3,94 & 21,09 \\
\hline 14 & 1 & -1 & 1 & 1 & 25 & 15 & 90 & 250 & 73,30 & 3,57 & 26,45 \\
\hline 15 & -1 & 1 & 1 & 1 & 15 & 25 & 90 & 250 & 74,84 & 3,77 & 23,02 \\
\hline 16 & 1 & 1 & 1 & 1 & 25 & 25 & 90 & 250 & 71,25 & 5,45 & 23,00 \\
\hline 17 & -2 & 0 & 0 & 0 & 10 & 20 & 75 & 230 & 73,13 & 3,61 & 21,34 \\
\hline 18 & 2 & 0 & 0 & 0 & 30 & 20 & 75 & 230 & 69,85 & 5,21 & 22,20 \\
\hline 19 & 0 & -2 & 0 & 0 & 20 & 10 & 75 & 230 & 71,86 & 4,50 & 20,43 \\
\hline 20 & 0 & 2 & 0 & 0 & 20 & 30 & 75 & 230 & 71,72 & 4,95 & 23,21 \\
\hline 21 & 0 & 0 & -2 & 0 & 20 & 20 & 45 & 230 & 70,49 & 4,80 & 23,82 \\
\hline 22 & 0 & 0 & 2 & 0 & 20 & 20 & 105 & 230 & 74,13 & 4,19 & 21,37 \\
\hline 23 & 0 & 0 & 0 & -2 & 20 & 20 & 75 & 190 & 73,12 & 4,36 & 21,03 \\
\hline 24 & 0 & 0 & 0 & 2 & 20 & 20 & 75 & 270 & 71,91 & 4,67 & 21,21 \\
\hline 25 & 0 & 0 & 0 & 0 & 20 & 20 & 75 & 230 & 72,77 & 4,10 & 21,12 \\
\hline
\end{tabular}

X1: Farelo de mandioca (\%); X2: Farinha de soja (\%); X3: Temperatura na $3^{\mathrm{a}}$ zona do extrusor $\left({ }^{\circ} \mathrm{C}\right)$; X4: Rotação da rosca $(\mathrm{rpm}) ; \mathrm{L}^{*}$ : luminosidade; croma $\mathrm{a}^{*}$; crom $\mathrm{b}^{*}$.

Após a extrusão observou-se que a luminosidade dos produtos variou de 64,11 a 75,25 mostrando ter ocorrido escurecimento independente do tratamento utilizado. A análise dos coeficientes de regressão evidenciou efeito linear da porcentagem de farelo de 
mandioca, temperatura e rotação, bem como, das interações entre a porcentagem de farelo de mandioca com farinha de soja e da temperatura com a rotação (Tabela 14).

Box \& Wetz (1973) sugeriram que para uma regressão ser significativa não apenas estatisticamente, mas também ser útil para fins preditivos, o valor de $\mathrm{F}$ calculado para a regressão deve ser no mínimo quatro a cinco vezes maiores que o valor de $\mathrm{F}$ tabelado. Portanto, o modelo obtido para o efeito dos parâmetros variáveis sobre a luminosidade dos produtos pode ser considerado preditivo.

Tabela 14 - Coeficientes de regressão estimados e ANOVA para a luminosidade (L*) dos produtos.

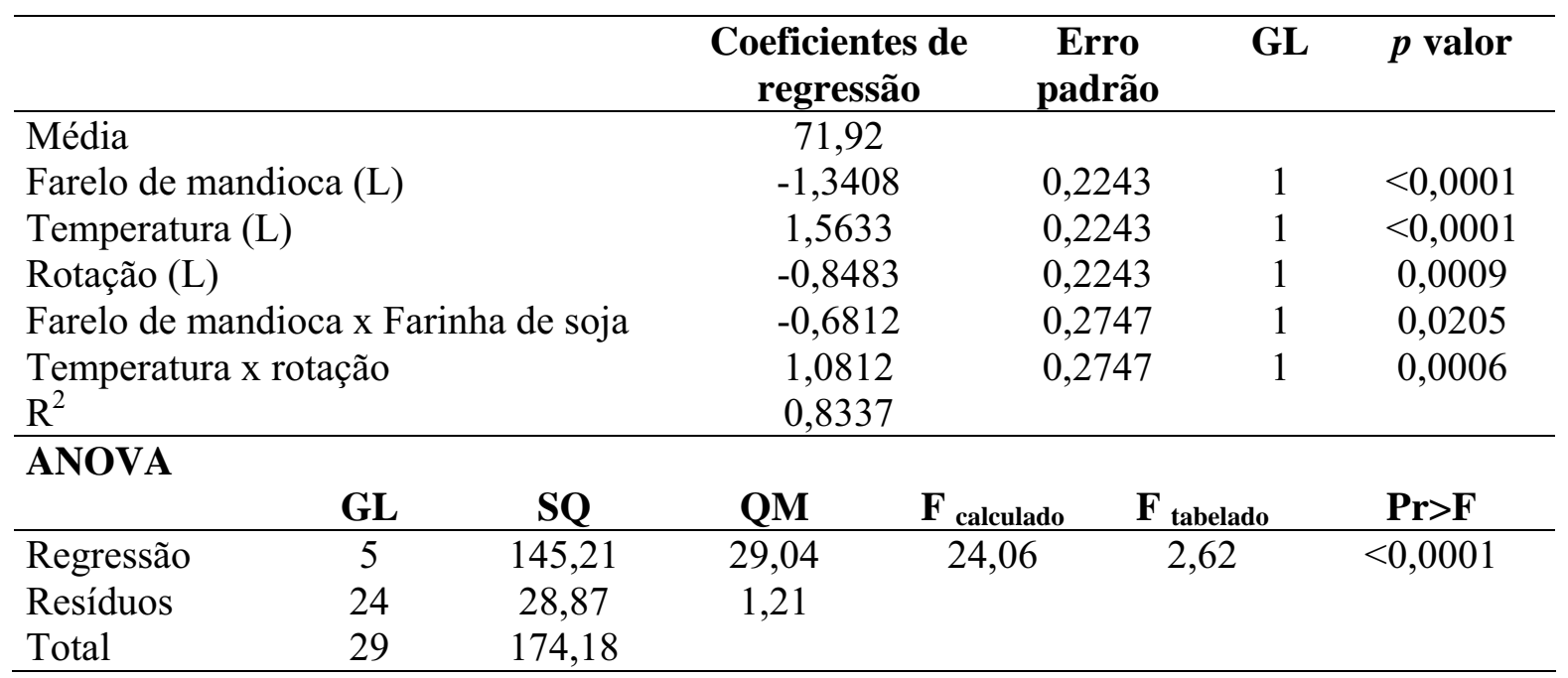

As condições de baixa temperatura de extrusão e elevada rotação testadas neste experimento proporcionaram menores valores de luminosidade, ou seja, produtos extrusados mais escuros (Figura 4). Além disso, observando a Figura 5, a luminosidade é menor quando o teor de farinha de soja e farelo de mandioca estão presentes na mistura em maior proporção.

Ilo \& Berghofer (1999) avaliaram diferentes parâmetros do processo de extrusão em produtos à base de milho e concluíram que os únicos parâmetros significativos na análise de cor foram à temperatura de processo e a umidade inicial das matérias-primas. Valores de $\mathrm{L}^{*}$ dos extrusados diminuíram com o aumento da temperatura $\left(140\right.$ a $\left.180^{\circ} \mathrm{C}\right) \mathrm{e}$ 
aumentaram ao se elevar a umidade (13 a 17\%). Os valores observados pelos autores foram de 73,00 a 86,17 valores superiores aos obtidos neste experimento.

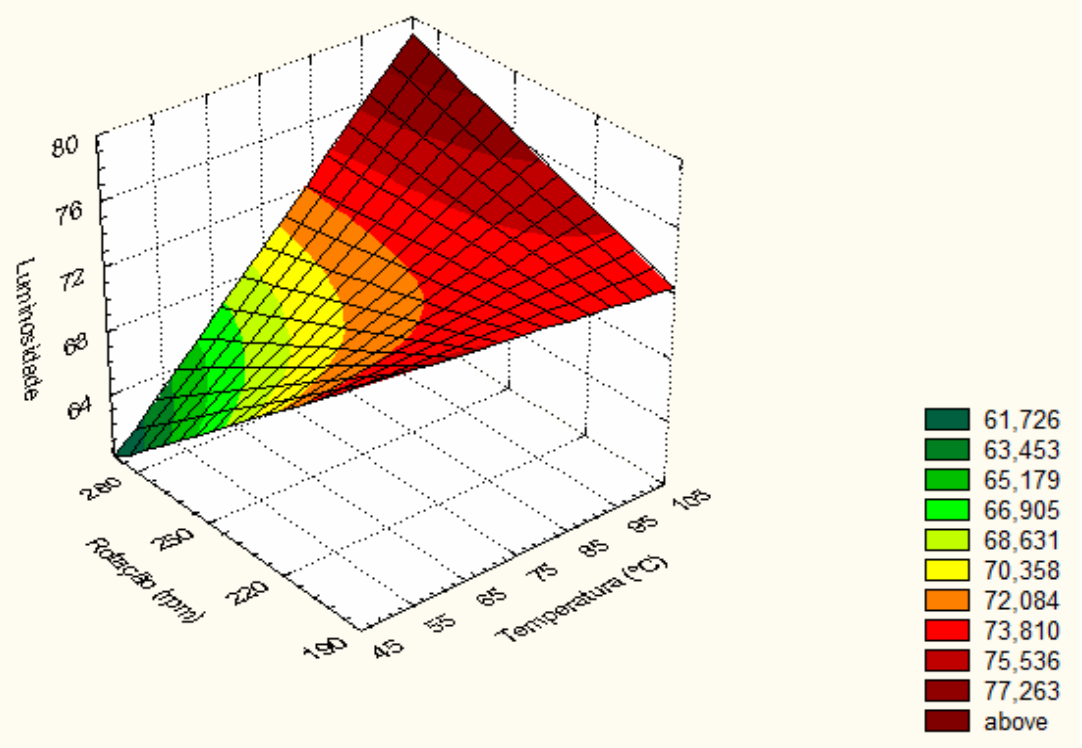

Figura 4- Efeito da rotação da rosca e da temperatura sobre a luminosidade das misturas extrusadas, com as porcentagens de farelo de mandioca e farinha de soja em $20 \%$.

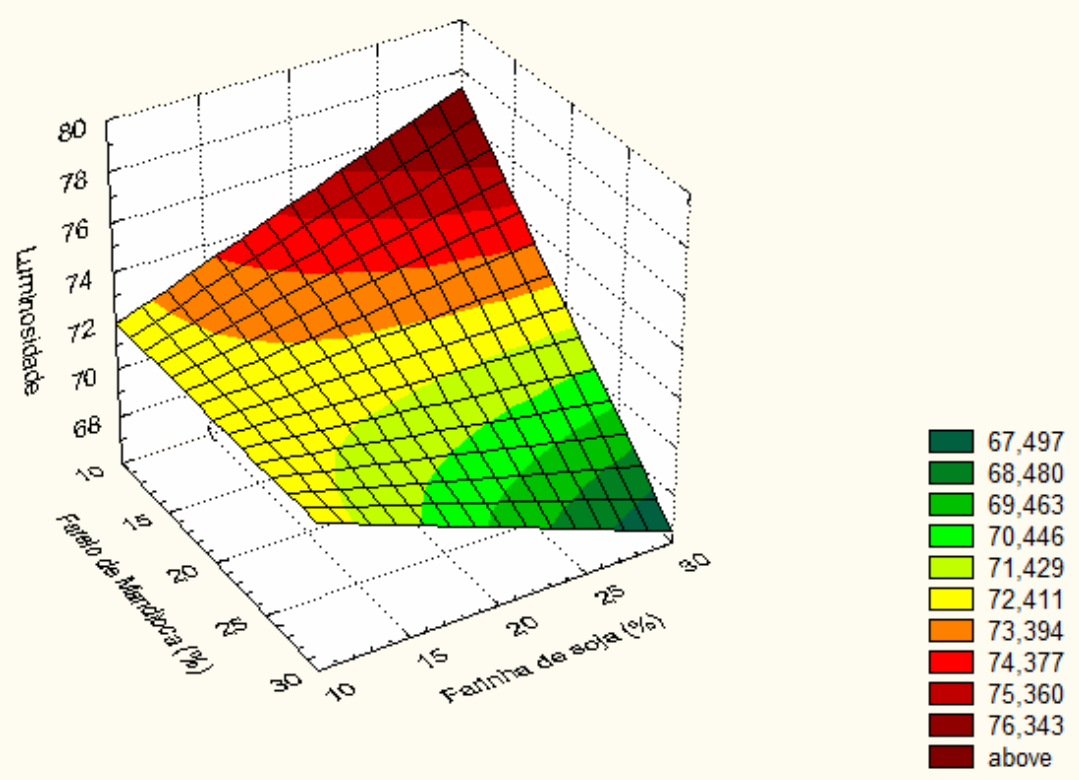

Figura 5- Efeito da porcentagem de farelo de mandioca e farinha de soja sobre a luminosidade das misturas extrusadas, com temperatura de extrusão de $75^{\circ} \mathrm{C}$ e rotação de $230 \mathrm{rpm}$. 
Leoro (2007), avaliando o efeito de farinha de milho e maracujá sobre a cor de cereal matinal extrusado à base de maracujá, observou a influência do teor de farelo de maracujá e da temperatura de extrusão nos produtos extrusados, os quais apresentaram $L^{*}$ variando de 68,26 a 44,15 com os menores valores obtidos nas maiores concentrações de farelo de maracujá. $\mathrm{O}$ aumento da temperatura produziu produtos mais claros.

Souza et al. (2007) verificando o efeito de parâmetro de extrusão sobre a cor de produtos à base de fécula de mandioca e fibra de laranja, observaram produtos mais claros nas condições de maior umidade $(22 \%)$, temperatura de $95^{\circ} \mathrm{C}$ e $10 \%$ de fibras de laranja na mistura.

Para o croma $a^{*}$, foi observada uma variação de 5,45 a 3,57 (Tabela 13), valores estes superiores aos observados nas misturas antes da extrusão. A análise dos dados mostrou terem ocorrido efeitos lineares da porcentagem de farelo de mandioca e temperatura, bem como, das interações de farelo de mandioca com rotação e temperatura de extrusão e rotação (Tabela 15).

Tabela 15- Coeficientes de regressão estimados e ANOVA para o croma (a*) dos produtos.

\begin{tabular}{|c|c|c|c|c|c|c|c|c|}
\hline & & & $\begin{array}{r}\text { Coefici } \\
\text { regr }\end{array}$ & $\begin{array}{l}\text { s de } \\
0\end{array}$ & $\begin{array}{r}\text { EI } \\
\text { pad }\end{array}$ & & GL & $p$ valor \\
\hline Média & & & 4,4 & & & & & \\
\hline Farelo de $n$ & $a(L)$ & & 0,3 & & 0,0 & & 1 & $<0,0001$ \\
\hline Temperatu & & & $-0,1$ & & 0,0 & & 1 & 0,0155 \\
\hline Farelo de $n$ & $\mathrm{a} \times \mathrm{r}$ & & $-0,2$ & & 0,0 & & 1 & 0,0297 \\
\hline Temperatu & ação & & $-0,2$ & & & & 1 & 0,0069 \\
\hline $\mathrm{R}^{2}$ & & & 0,6 & & & & & \\
\hline ANOVA & & & & & & & & \\
\hline & GL & SQ & QM & $\mathbf{F}_{\text {cal }}$ & & & & Pr $>F$ \\
\hline Regressão & 4 & 6,4311 & 1,6078 & & & & & $<0,0001$ \\
\hline Resíduos & 25 & 3,2394 & 0,1296 & & & & & \\
\hline Total & 29 & 9,6705 & & & & & & \\
\hline
\end{tabular}

Nas condições de baixa temperatura e rotação e também nos seus inversos, o croma a* é menor nos produtos extrusados (Figura 6). Nas condições de maior teor de farelo de mandioca na mistura e baixa rotação foi encontrado os maiores valores do croma $a^{*}$ (Figura 7). 


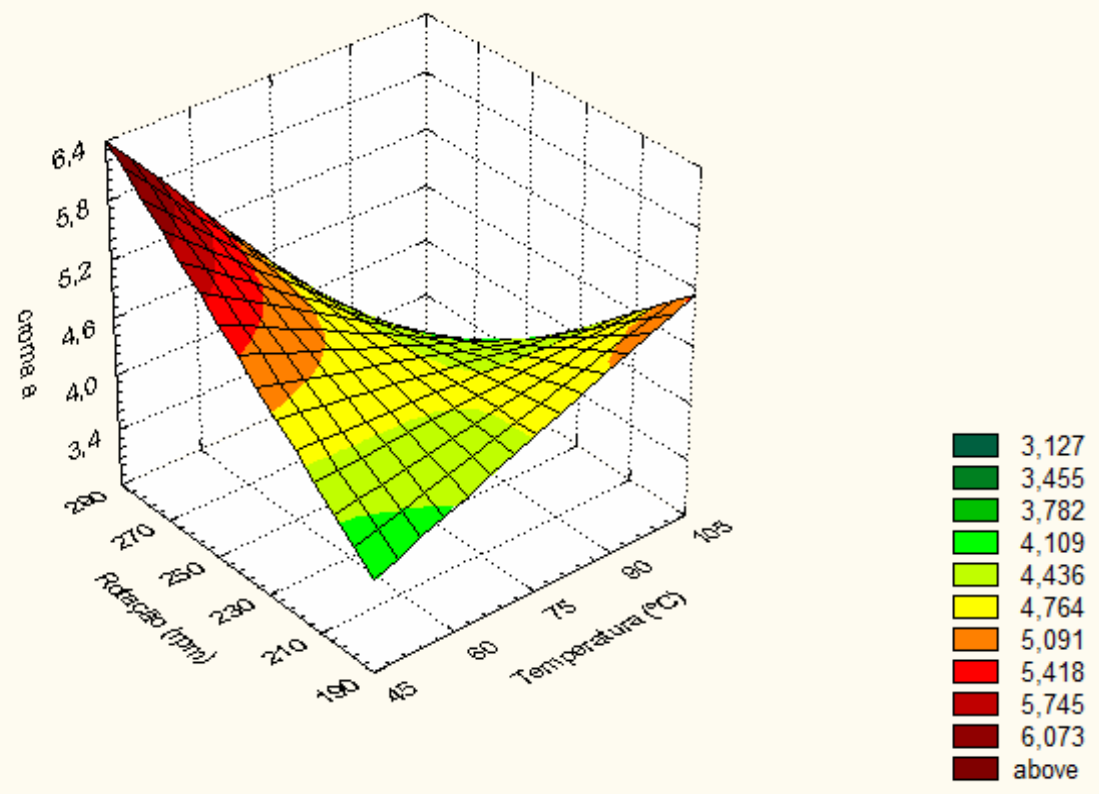

Figura 6- Efeito da rotação da rosca e da temperatura sobre o croma a* nas misturas após a extrusão, com as porcentagens de farelo de mandioca e farinha de soja em $20 \%$.

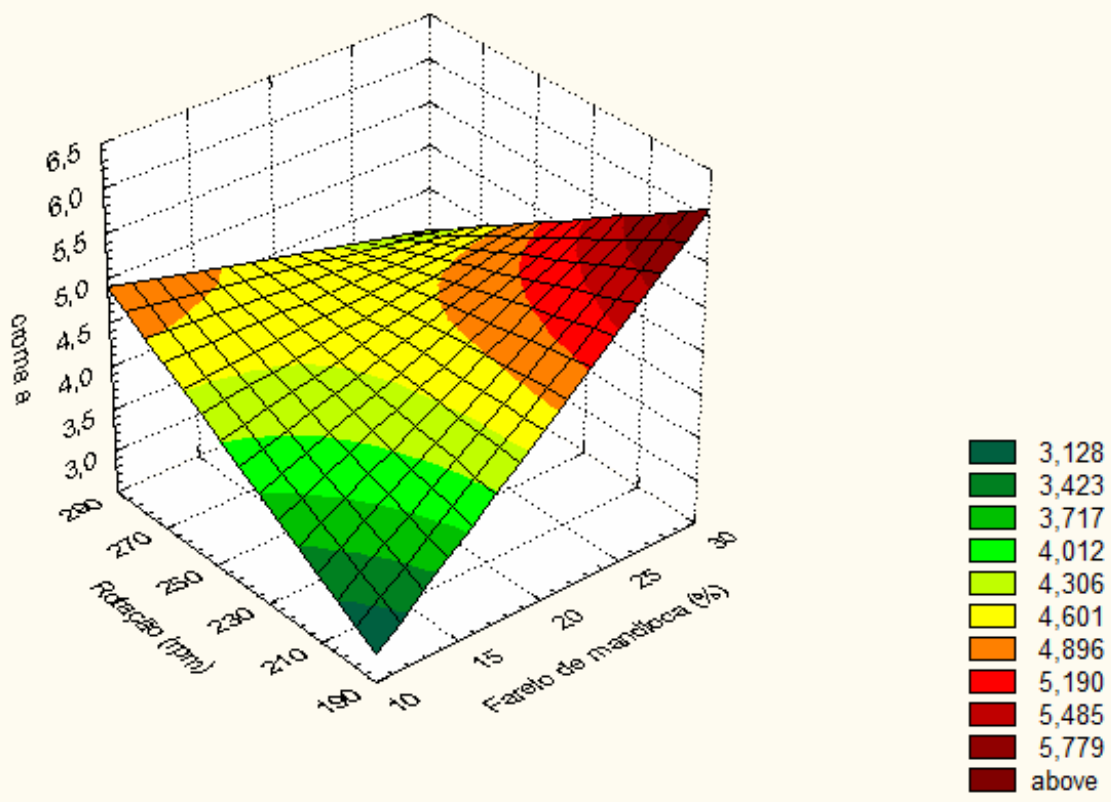

Figura 7- Efeito da rotação e do teor de farelo de mandioca sobre o croma a* das misturas após a extrusão, com a porcentagem de farinha de soja em $20 \%$ e temperatura de extrusão de $75^{\circ} \mathrm{C}$. 
A variação observada para o croma $b^{*}$ nos diferentes tratamentos foi de 20,43 a 26,45 (Tabela 13), o que evidencia o aumento da presença deste croma com o processo de extrusão. A análise estatística mostrou a influência da porcentagem de farelo de mandioca (linear), da temperatura de extrusão (quadrática) e da interação das porcentagens de farelo de mandioca e farinha de soja sobre este parâmetro de cor (Tabela 16). De acordo com o modelo ajustado nas condições intermediárias de temperatura o croma b* é menor (Figura 8).

Tabela16 - Coeficientes de regressão estimados e ANOVA para o croma ( $\left.b^{*}\right)$ dos produtos.

\section{Coeficientes Erro GL $p$ valor de regressão padrão}

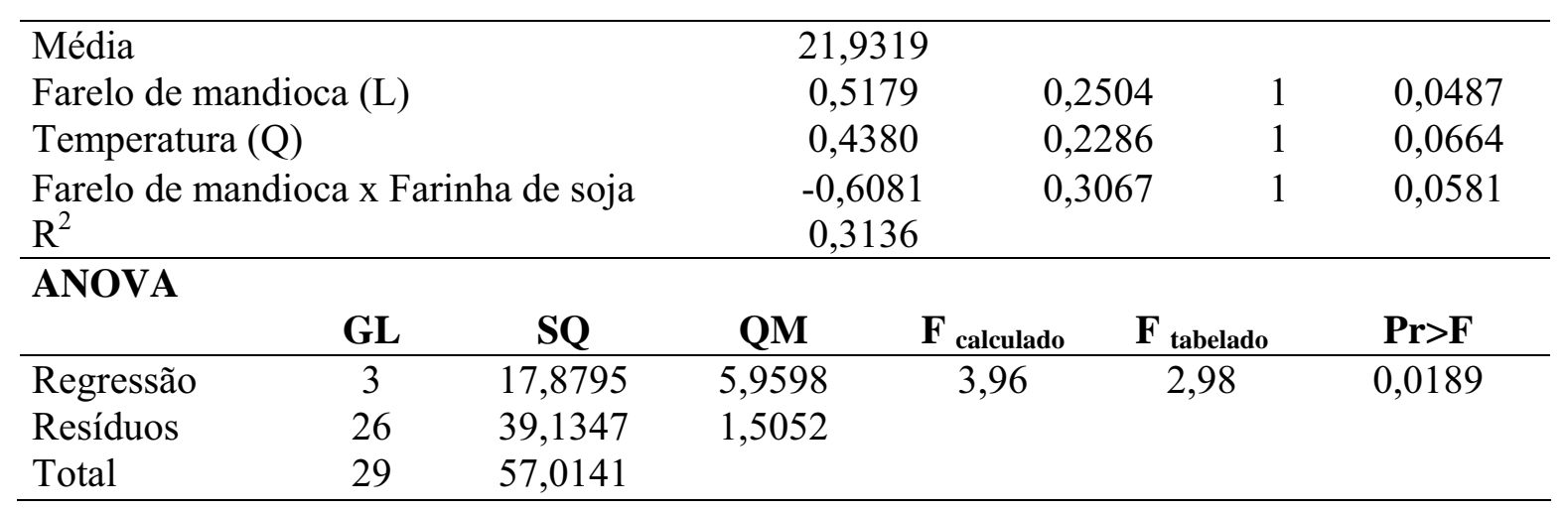

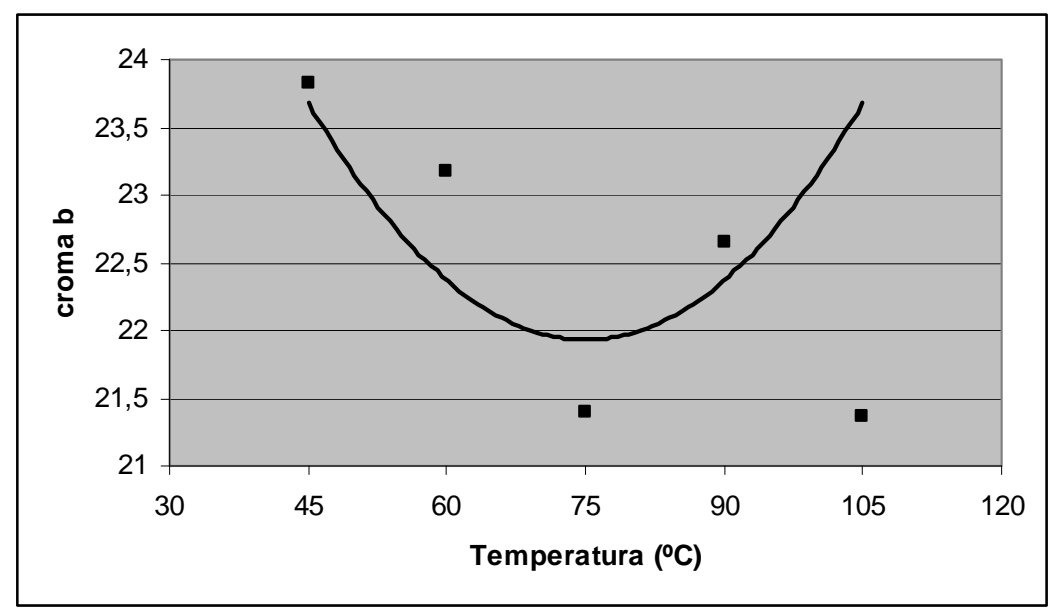

Figura 8- Efeito da temperatura de extrusão sobre o croma $b^{*}$ das misturas extrusadas, com as porcentagens de farelo de mandioca e farinha de soja em $20 \%$ e rotação de $230 \mathrm{rpm}$. 
A Figura 9 mostra que o parâmetro de cor b* que varia do azul ao amarelo é maior na condição de elevado teor de farelo de mandioca e baixa concentração de farinha de soja.

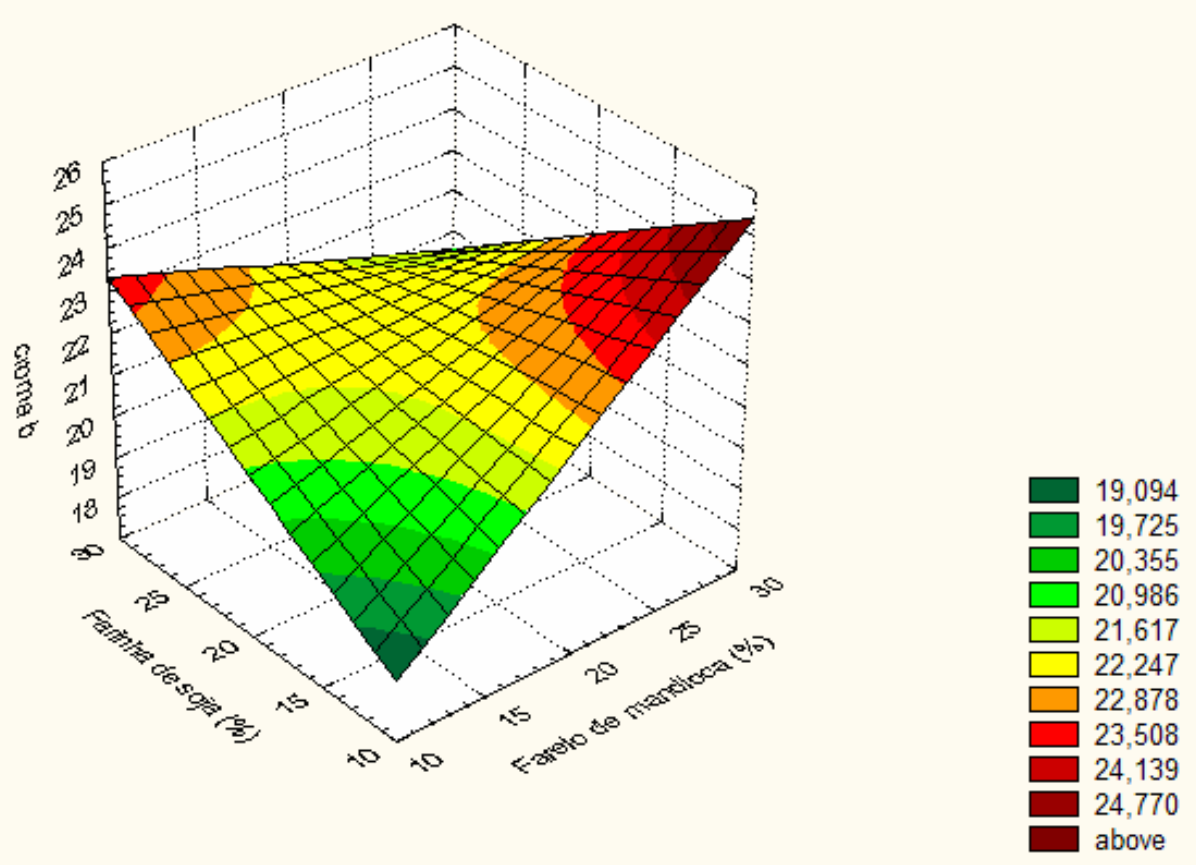

Figura 9- Efeito do teor de farelo de mandioca e farinha de soja nas farinhas extrusadas sobre o croma $b^{*}$, com a temperatura de extrusão de $75^{\circ} \mathrm{C}$ e rotação de $230 \mathrm{rpm}$.

\subsection{2. Índices de absorção de água (IAA) e solubilidade em água (ISA)}

Os resultados obtidos para os índices de absorção em água e solubilidade em água das misturas de fécula, farelo de mandioca e farinha de soja após os diferentes tratamentos de extrusão estão apresentados na Tabela 17.

Os resultados obtidos para IAA variaram de 5,8 a $8,82 \%$. A análise dos coeficientes de regressão para o índice de absorção em água (IAA) mostrou ter havido influência dos fatores: farinha de soja, temperatura, e interação temperatura e rotação (Tabela 
18). Nas condições de elevado teor de farinha de soja e baixa temperatura são obtidos os menores IAA (Figura 10).

Tabela 17 - Índice de solubilidade em água (ISA) e absorção de água (IAA) das farinhas extrusadas sob as diferentes condições experimentais.

\begin{tabular}{|c|c|c|c|c|c|c|c|c|c|c|}
\hline & \multicolumn{4}{|c|}{ Níveis Codificados } & \multicolumn{4}{|c|}{$\begin{array}{c}\text { Variáveis } \\
\text { Independentes }\end{array}$} & \multicolumn{2}{|c|}{$\begin{array}{c}\text { Variáveis } \\
\text { Dependentes }\end{array}$} \\
\hline Trat & $\mathrm{X} 1$ & $\mathrm{X} 2$ & $\mathrm{X} 3$ & $\mathrm{X} 4$ & FM & FS & $\mathrm{T}$ & $\mathrm{R}$ & $\begin{array}{c}\text { IAA } \\
\text { (g gel/g) }\end{array}$ & $\begin{array}{l}\text { ISA } \\
(\%)\end{array}$ \\
\hline 1 & -1 & -1 & -1 & -1 & 15 & 15 & 60 & 210 & 8,4 & 14,95 \\
\hline 2 & 1 & -1 & -1 & -1 & 25 & 15 & 60 & 210 & 7,63 & 14,39 \\
\hline 3 & -1 & 1 & -1 & -1 & 15 & 25 & 60 & 210 & 8,17 & 17,1 \\
\hline 4 & 1 & 1 & -1 & -1 & 25 & 25 & 60 & 210 & 7,29 & 13,84 \\
\hline 5 & -1 & -1 & 1 & -1 & 15 & 15 & 90 & 210 & 8,46 & 22,88 \\
\hline 6 & 1 & -1 & 1 & -1 & 25 & 15 & 90 & 210 & 8,42 & 20,41 \\
\hline 7 & -1 & 1 & 1 & -1 & 15 & 25 & 90 & 210 & 8,25 & 19,4 \\
\hline 8 & 1 & 1 & 1 & -1 & 25 & 25 & 90 & 210 & 7,8 & 21,4 \\
\hline 9 & -1 & -1 & -1 & 1 & 15 & 15 & 60 & 250 & 5,96 & 12,94 \\
\hline 10 & 1 & -1 & -1 & 1 & 25 & 15 & 60 & 250 & 6,77 & 16,33 \\
\hline 11 & -1 & 1 & -1 & 1 & 15 & 25 & 60 & 250 & 5,76 & 15,27 \\
\hline 12 & 1 & 1 & -1 & 1 & 25 & 25 & 60 & 250 & 6,1 & 14,35 \\
\hline 13 & -1 & -1 & 1 & 1 & 15 & 15 & 90 & 250 & 8,82 & 25,2 \\
\hline 14 & 1 & -1 & 1 & 1 & 25 & 15 & 90 & 250 & 9,47 & 21,3 \\
\hline 15 & -1 & 1 & 1 & 1 & 15 & 25 & 90 & 250 & 7 & 21,17 \\
\hline 16 & 1 & 1 & 1 & 1 & 25 & 25 & 90 & 250 & 7,33 & 21,9 \\
\hline 17 & -2 & 0 & 0 & 0 & 10 & 20 & 75 & 230 & 7,67 & 18,25 \\
\hline 18 & 2 & 0 & 0 & 0 & 30 & 20 & 75 & 230 & 5,8 & 12,89 \\
\hline 19 & 0 & -2 & 0 & 0 & 20 & 10 & 75 & 230 & 8,47 & 10,31 \\
\hline 20 & 0 & 2 & 0 & 0 & 20 & 30 & 75 & 230 & 6,06 & 13,37 \\
\hline 21 & 0 & 0 & -2 & 0 & 20 & 20 & 45 & 230 & 6,07 & 11,54 \\
\hline 22 & 0 & 0 & 2 & 0 & 20 & 20 & 105 & 230 & 7,06 & 15,73 \\
\hline 23 & 0 & 0 & 0 & -2 & 20 & 20 & 75 & 190 & 6,04 & 8,93 \\
\hline 24 & 0 & 0 & 0 & 2 & 20 & 20 & 75 & 270 & 7,17 & 11,3 \\
\hline 25 & 0 & 0 & 0 & 0 & 20 & 20 & 75 & 230 & 6,53 & 10,33 \\
\hline
\end{tabular}

X1: farelo de mandioca (\%); X2: farinha de soja (\%); X3: temperatura na $3^{\mathrm{a}}$ zona do extrusor $\left({ }^{\circ} \mathrm{C}\right)$; X4: rotação da rosca (rpm); IAA: índice de absorção de agua (g gel/g); ISA: índice de solubilidade em água (\%). 
TABELA 18 - Coeficientes de regressão estimados e ANOVA para o índice de absorção de água (IAA) das misturas extrusadas.

\begin{tabular}{|c|c|c|c|c|c|c|}
\hline & & \multicolumn{2}{|c|}{$\begin{array}{l}\text { Coeficientes de } \\
\text { regressão }\end{array}$} & Erro padrão & GL & $p$ valor \\
\hline Média & & \multicolumn{2}{|c|}{7,1620} & & & \\
\hline Farinha de & & \multicolumn{2}{|c|}{$-0,4604$} & 0,1685 & 1 & 0,0112 \\
\hline Temperatur & & \multicolumn{2}{|c|}{0,4771} & 0,1685 & 1 & 0,0088 \\
\hline $\begin{array}{l}\text { Temperatur } \\
\mathrm{R}^{2}\end{array}$ & & \multicolumn{2}{|c|}{0,4119} & 0,2064 & 1 & 0,0566 \\
\hline \multicolumn{7}{|l|}{ ANOVA } \\
\hline & GL & SQ & QM & $\mathrm{F}_{\text {calculado }}$ & $\mathrm{F}_{\text {tabelado }}$ & $\operatorname{Pr}>F$ \\
\hline Regressão & 3 & 13,2644 & 4,4215 & 6,49 & 2,98 & 0,0020 \\
\hline Resíduos & 26 & 17,7244 & 0,6817 & & & \\
\hline Total & 29 & & & & & \\
\hline
\end{tabular}
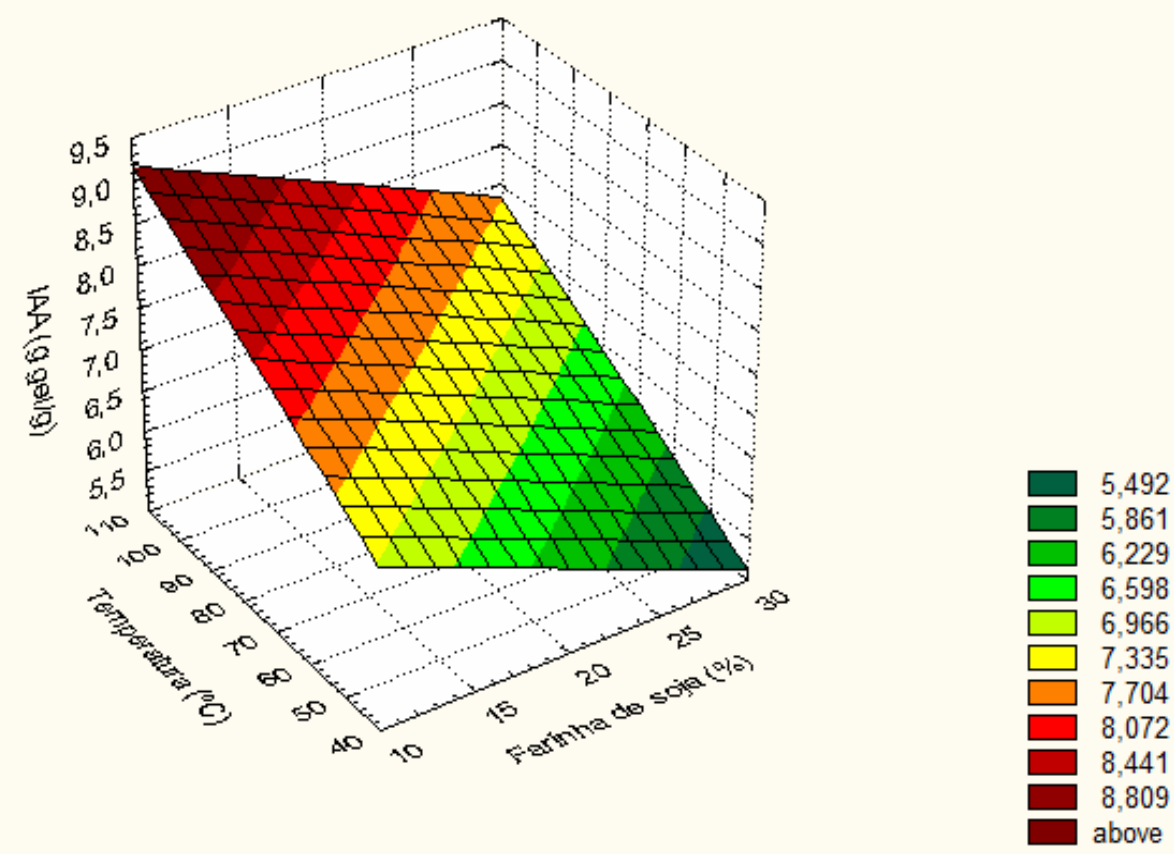

Figura 10 - Efeito da porcentagem de farinha de soja na mistura e da temperatura de extrusão sobre o índice de absorção de água das misturas, sob rotação de $230 \mathrm{rpm}$ e $20 \%$ de farelo de mandioca na mistura. 
De acordo com Alvin et al., (2002), o IAA está relacionado à capacidade de absorção e retenção de água pelos constituintes da matéria-prima. Durante a extrusão, os grânulos de amido sofrem gelatinização e as proteínas são desnaturadas. O amido gelatinizado absorve mais água do que em seu estado natural e as proteínas, devido a mudanças conformacionais e estruturais, têm o seu balanço hidrofílico/hidrofóbico alterado, podendo contribuir para o aumento ou a diminuição do IAA (MAIA et al., 1999).

Mesa et al., (2009), estudando o efeito da rotação da rosca e porcentagem de concentrado protéico de soja na produção de snacks fortificados de amido de milho, observaram o efeito dos dois fatores sobre os IAA e ISA dos produtos, com baixo valor de IAA nas condições de alta rotação da rosca e maiores porcentagens de concentrado protéico de soja. Já o ISA foi maior nas condições de elevada rotação (330 rpm) e alto conteúdo de concentrado de soja $(20 \%)$.

O Índice de Solubilidade (ISA) é um parâmetro que reflete o grau de degradação do grânulo de amido, ou seja, a somatória dos efeitos de gelatinização, dextrinização e conseqüente solubilização. O aumento da solubilidade verificado em produtos extrusados é atribuído à dispersão das moléculas de amilose e amilopectina como conseqüência da gelatinização, quando as condições são mais brandas, e da formação de compostos de baixo peso molecular, quando as condições são mais drásticas (COLONNA et al., 1984).

Os resultados obtidos para o ISA, nos diferentes tratamentos após a extrusão mostraram uma variação de 8,93 a 25,2\% (Tabela 17). Os coeficientes de regressão e ANOVA para o modelo ajustado para o ISA mostraram efeitos significativos para a temperatura linear e quadrática, e farelo de mandioca efeito quadrático (Tabela 19).

As superfícies de resposta traçadas a partir dos modelos ajustados mostram que nas condições centrais testadas de temperatura, porcentagem de farelo de mandioca e farinha de soja a $20 \%$, são obtidos os menores valores para ISA. Já nas condições extremas opostas de farelo de mandioca e temperatura, bem como, nas condições de baixa rotação e temperatura e nos seus inversos são obtidos os maiores índices de absorção de água (Figura 11). 
TABELA 19 - Coeficientes de regressão estimados e ANOVA para o índice de solubilidade em água (ISA) das misturas extrusadas (modelo ajustado).

\begin{tabular}{|c|c|c|c|c|c|c|}
\hline & & $\begin{array}{r}\text { Coefi } \\
\text { reg }\end{array}$ & $\begin{array}{l}\text { es de } \\
\text { âo }\end{array}$ & Erro padrão & GL & $p$ valor \\
\hline Média & & & & & & \\
\hline Temperatur & & & & 0,6995 & 1 & 0,0009 \\
\hline Farelo de $\mathrm{m}$ & (Q) & & & 0,6425 & 1 & 0,0054 \\
\hline Temperatur & & & & 0,6425 & 1 & 0,0311 \\
\hline $\mathrm{R}^{2}$ & & & & & & \\
\hline ANOVA & & & & & & \\
\hline & GL & SQ & QM & $\mathrm{F}_{\text {calculado }}$ & $\mathrm{F}_{\text {tabelado }}$ & $\operatorname{Pr}>\mathrm{F}$ \\
\hline Regressão & 3 & 317,51 & 105,84 & 9,01 & 2,98 & 0,0003 \\
\hline Resíduos & 26 & 305,31 & 11,74 & & & \\
\hline Total & 29 & 622,82 & & & & \\
\hline
\end{tabular}
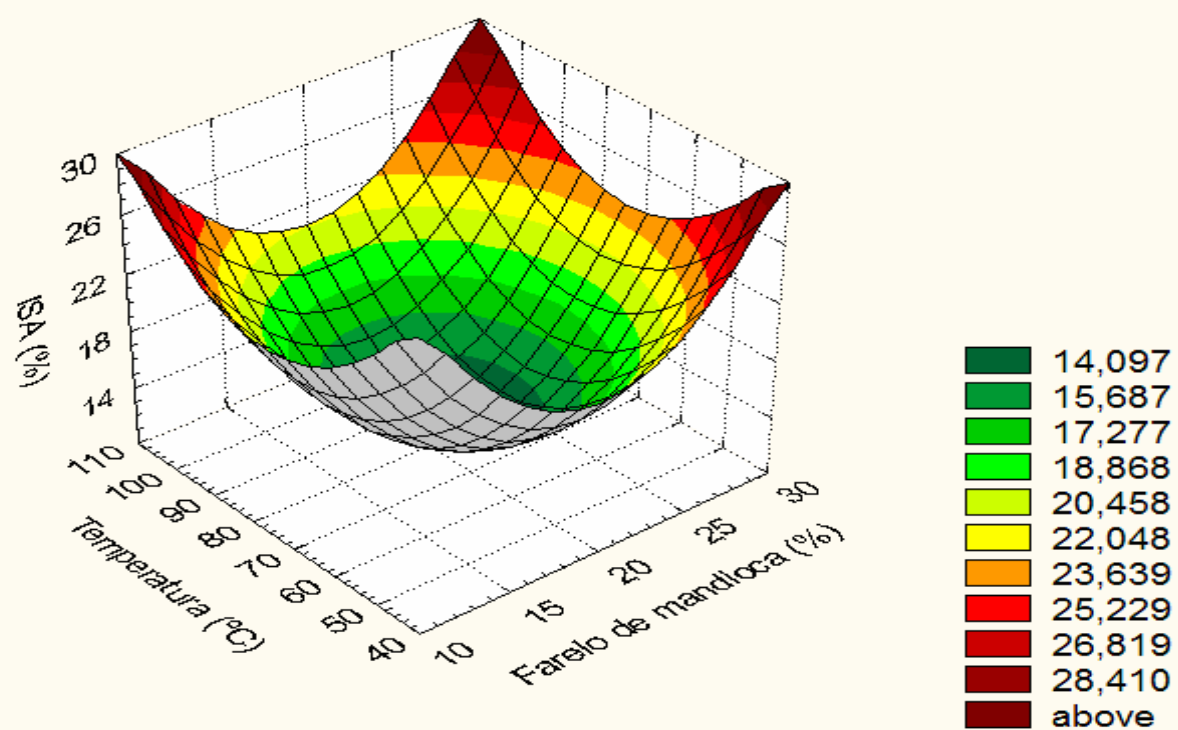

Figura 11 - Efeito da porcentagem de farelo de mandioca na mistura e da temperatura de extrusão sobre o índice de solubilidade em água das misturas, sob rotação de $230 \mathrm{rpm}$ e $20 \%$ de farinha de soja na mistura. 
A desnaturação e a insolubilização da fração protéica, nas misturas de milho com frações protéicas de leguminosas com o aumento da temperatura do extrusor, diminuíram o seu ISA (GUJSKA \& KHAN, 1991). Por outro lado, o ISA das misturas extrusadas de arroz e soja aumentou nitidamente depois da adição de farinha de soja desengordurada, resultado atribuído ao alto teor de proteínas solúveis da soja (CHAUHAN \& BAINS, 1985).

Larrea et al., (2005), afirmaram que os materiais solúveis são constituídos principalmente de substâncias pécticas e hemiceluloses. Os autores apontam que o processo de extrusão aumenta a concentração dos componentes solúveis da fibra (xilose, galactose e ácido urônico), ou seja, o ISA aumenta. Além disso, indicam que este aumento pode ocorrer em função da solubilização de substâncias pécticas neutras ou de ligações laterais, e não devido à degradação das ligações centrais de ramnogalacturonas e da cadeia central de celulose. Esses mesmos autores, avaliando algumas propriedades funcionais de extrusados de polpa de laranja (alto teor de fibra alimentar) encontraram que o ISA aumentou com o aumento da temperatura de extrusão e teores de umidade abaixo de $27 \%$. Tais condições possibilitaram um aumento na fração solúvel de fibra alimentar, como no caso da pectina solúvel.

\subsubsection{Propriedades de pasta}

A curva de viscosidade representa o comportamento durante o aquecimento e permite avaliar as características da pasta formada, devido às modificações estruturais das moléculas de amido, e de outros componentes e, também, à tendência a retrogradação durante o resfriamento.

A Tabela 20 apresenta os resultados experimentais obtidos para as propriedades de pasta das misturas extrusadas, nas diferentes condições experimentais. 
Tabela 20- Propriedades de pasta das misturas extrusadas nos diferentes tratamentos.

\begin{tabular}{|c|c|c|c|c|c|c|c|c|c|c|c|c|c|}
\hline & \multicolumn{4}{|c|}{$\begin{array}{c}\text { Níveis } \\
\text { codificados }\end{array}$} & \multicolumn{4}{|c|}{$\begin{array}{c}\text { Variáveis } \\
\text { independentes }\end{array}$} & \multicolumn{5}{|c|}{$\begin{array}{c}\text { Variáveis } \\
\text { dependentes }\end{array}$} \\
\hline Trat. & X1 & $\mathrm{X} 2$ & X3 & X4 & FM & FS & $\mathbf{T}$ & $\mathbf{R}$ & VI & PV & $\mathbf{Q V}$ & VF & TR \\
\hline 1 & -1 & -1 & -1 & -1 & 15 & 15 & 60 & 210 & 21,42 & 25,92 & 18,50 & 8,00 & 0,58 \\
\hline 2 & 1 & -1 & -1 & -1 & 25 & 15 & 60 & 210 & 29,58 & 28,83 & 21,16 & 10,92 & 3,25 \\
\hline 3 & -1 & 1 & -1 & -1 & 15 & 25 & 60 & 210 & 49,08 & 42,92 & 35,75 & 13,08 & 5,91 \\
\hline 4 & 1 & 1 & -1 & -1 & 25 & 25 & 60 & 210 & 16,50 & 23,33 & 15,16 & 8,42 & 0,25 \\
\hline 5 & -1 & -1 & 1 & -1 & 15 & 15 & 90 & 210 & 34,42 & 30,58 & 23,58 & 8,42 & 1,42 \\
\hline 6 & 1 & -1 & 1 & -1 & 25 & 15 & 90 & 210 & 28,08 & 27,08 & 22,75 & 7,08 & 2,75 \\
\hline 7 & -1 & 1 & 1 & -1 & 15 & 25 & 90 & 210 & 25,83 & 28,17 & 18,25 & 11,75 & 1,83 \\
\hline 8 & 1 & 1 & 1 & -1 & 25 & 25 & 90 & 210 & 27,17 & 26,75 & 24,25 & 5,08 & 2,58 \\
\hline 9 & -1 & -1 & -1 & 1 & 15 & 15 & 60 & 250 & 27,92 & 32,25 & 23,67 & 13,33 & 4,75 \\
\hline 10 & 1 & -1 & -1 & 1 & 25 & 15 & 60 & 250 & 32,8 & 31,33 & 26,00 & 8,92 & 3,59 \\
\hline 11 & -1 & 1 & -1 & 1 & 15 & 25 & 60 & 250 & 15,75 & 18,92 & 14,65 & 5,58 & 0,91 \\
\hline 12 & 1 & 1 & -1 & 1 & 25 & 25 & 60 & 250 & 18,00 & 20,83 & 14,50 & 6,33 & 0,00 \\
\hline 13 & -1 & -1 & 1 & 1 & 15 & 15 & 90 & 250 & 35,00 & 39,58 & 29,25 & 12,25 & 2,92 \\
\hline 14 & 1 & -1 & 1 & 1 & 25 & 15 & 90 & 250 & 32,83 & 31,92 & 30,16 & 6,33 & 3,66 \\
\hline 15 & -1 & 1 & 1 & 1 & 15 & 25 & 90 & 250 & 11,00 & 16,75 & 11,58 & 6,50 & 1,33 \\
\hline 16 & 1 & 1 & 1 & 1 & 25 & 25 & 90 & 250 & 18,33 & 20,08 & 10,75 & 10,08 & 0,75 \\
\hline 17 & -2 & 0 & 0 & 0 & 10 & 20 & 75 & 230 & 40,67 & 41,92 & 34,17 & 13,33 & 5,58 \\
\hline 18 & 2 & 0 & 0 & 0 & 30 & 20 & 75 & 230 & 14,42 & 21,33 & 11,58 & 10,75 & 1,00 \\
\hline 19 & 0 & -2 & 0 & 0 & 20 & 10 & 75 & 230 & 62,08 & 73,67 & 65,84 & 15,42 & 7,59 \\
\hline 20 & 0 & 2 & 0 & 0 & 20 & 30 & 75 & 230 & 7,25 & 14,5 & 8,75 & 6,25 & 0,50 \\
\hline 21 & 0 & 0 & -2 & 0 & 20 & 20 & 45 & 230 & 18,00 & 18,25 & 13,58 & 6,33 & 1,66 \\
\hline 22 & 0 & 0 & 2 & 0 & 20 & 20 & 105 & 230 & 22,17 & 26,67 & 20,25 & 8,67 & 2,25 \\
\hline 23 & 0 & 0 & 0 & -2 & 20 & 20 & 75 & 190 & 14,75 & 114,92 & 108,42 & 7,00 & 0,50 \\
\hline 24 & 0 & 0 & 0 & 2 & 20 & 20 & 75 & 270 & 14,08 & 25,92 & 18,00 & 8,17 & 0,25 \\
\hline 25 & 0 & 0 & 0 & 0 & 20 & 20 & 75 & 230 & 16,25 & 28,92 & 19,50 & 8,67 & 0,25 \\
\hline 25 & 0 & 0 & 0 & 0 & 20 & 20 & 75 & 230 & 15,33 & 28,75 & 20,83 & 8,17 & 0,25 \\
\hline 25 & 0 & 0 & 0 & 0 & 20 & 20 & 75 & 230 & 16,92 & 29,54 & 22,25 & 7,6 & 0,31 \\
\hline 25 & 0 & 0 & 0 & 0 & 20 & 20 & 75 & 230 & 17,42 & 29,62 & 22,34 & 7,63 & 0,35 \\
\hline 25 & 0 & 0 & 0 & 0 & 20 & 20 & 75 & 230 & 15,58 & 29,33 & 20,98 & 8,04 & 0,31 \\
\hline 25 & 0 & 0 & 0 & 0 & 20 & 20 & 75 & 230 & 15,83 & 29,17 & 20,22 & 9,23 & 0,28 \\
\hline
\end{tabular}

X1: farelo de mandioca (\%); X2: farinha de soja (\%); X3: temperatura na $3^{\mathrm{a}}$ zona do extrusor $\left({ }^{\circ} \mathrm{C}\right)$; X4: rotação da rosca (rpm); VI: viscosidade inicial (RVU); PV: pico de viscosidade (RVU); QV: quebra de viscosidade (RVU); VF: viscosidade final (RVU); TR: tendência a retrogradação (RVU) .

\subsubsection{Viscosidade inicial (VI)}

A viscosidade inicial ou viscosidade de pasta a frio indica a capacidade das farinhas em absorver água a temperatura ambiente e formar pasta, gel ou 
líquido viscoso (CARVALHO et al., 2002). Os resultados obtidos nas farinhas extrusadas de fécula e farelo de mandioca e farinha de soja, para este parâmetro variam de 7,25 a 62,08 RVU (Tabela 20).

A análise dos coeficientes de regressão mostrou ter ocorrido influência significativa de todos os fatores sobre a viscosidade inicial (VI) dos produtos extrusados (Tabela 21). Mantendo a temperatura à $75^{\circ} \mathrm{C}$ e variando a proporção de farinha de soja em maior quantidade, a viscosidade inicial é maior, enquanto que, o aumento de farelo de mandioca na mesma temperatura e rotação a viscosidade inicial é menor (Figura 12).

Nas condições de elevada rotação e baixa porcentagem de farinha de soja na mistura, a viscosidade inicial das farinhas extrusadas é maior de acordo com a superfície de resposta traçada a partir do modelo ajustado (Figura 13).

Tabela 21- Coeficientes de regressão estimados e ANOVA para a viscosidade inicial das misturas extrusadas (modelo ajustado).

\begin{tabular}{|c|c|c|c|c|c|c|}
\hline & & \multicolumn{2}{|c|}{$\begin{array}{l}\text { Coeficientes de } \\
\text { regressão }\end{array}$} & Erro padrão & GL & $p$ valor \\
\hline Média & & \multicolumn{2}{|c|}{17,50} & & & \\
\hline \multicolumn{2}{|c|}{ Farinha de soja (L) } & \multicolumn{2}{|c|}{$-7,09$} & 1,724 & 1 & 0,0004 \\
\hline \multicolumn{2}{|c|}{ Farelo de mandioca (Q) } & \multicolumn{2}{|c|}{3,05} & 1,584 & 1 & 0,0652 \\
\hline \multicolumn{2}{|c|}{ Farinha de soja (Q) } & \multicolumn{2}{|c|}{4,83} & 1,584 & 1 & 0,0053 \\
\hline \multicolumn{2}{|c|}{ Farinha de soja x rotação } & \multicolumn{2}{|c|}{$-4,41$} & 2,111 & 1 & 0,0471 \\
\hline $\mathrm{R}^{2}$ & & \multicolumn{2}{|c|}{0,57} & & & \\
\hline \multicolumn{7}{|l|}{ ANOVA } \\
\hline & GL & SQ & QM & $\mathrm{F}_{\text {calculado }}$ & $\mathrm{F}_{\text {tabelado }}$ & $\operatorname{Pr}>\mathrm{F}$ \\
\hline Regressão & 4 & 2364,10 & 591,02 & 8,28 & 2,80 & 0,0002 \\
\hline Resíduos & 25 & 4148,10 & 71,36 & & & \\
\hline Total & 29 & & & & & \\
\hline
\end{tabular}


Nas amostras extrusadas, o amido está gelatinizado, e torna possível a rápida hidratação dos grânulos a temperatura ambiente, sendo importante em produtos em que se deseja maior viscosidade a frio. No caso de tratamentos de extrusão pouco severos, determinada porcentagem de grânulos de amido pode conservar parte da estrutura amilácea, apresentando um pico no perfil amilográfico, que significa amido não gelatinizado ou parcialmente gelatinizado (GUHA et al., 1998).

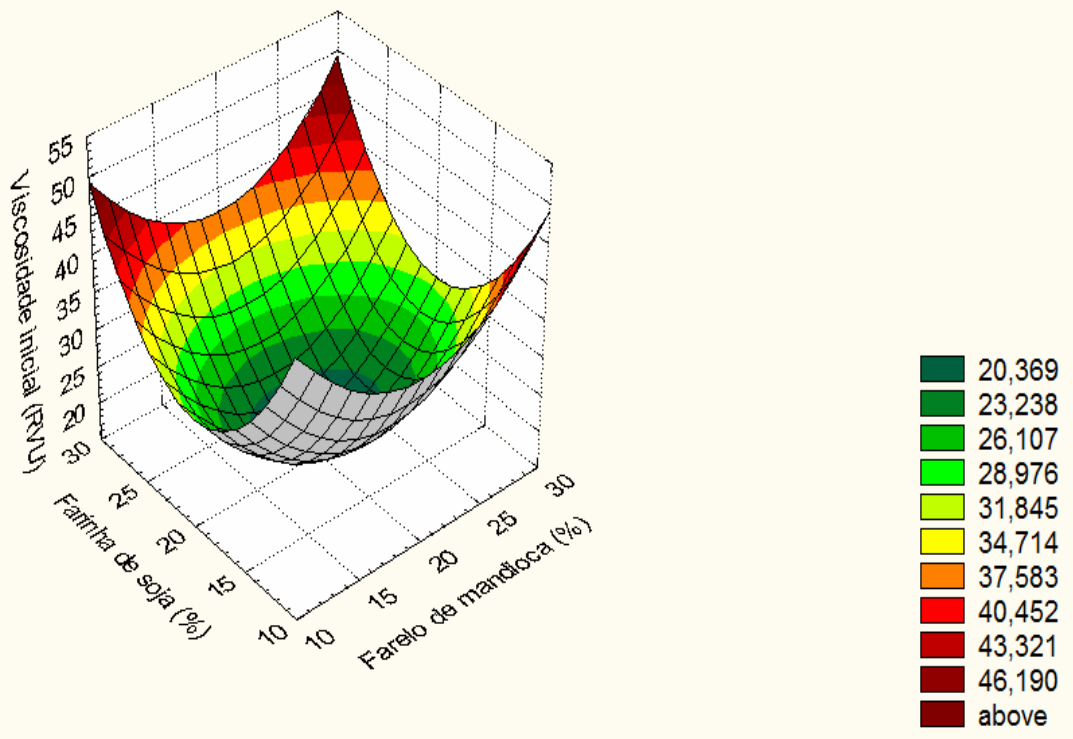

Figura 12 - Efeito da porcentagem de farinha de soja e farelo de mandioca na mistura sobre a viscosidade inicial das misturas extrusadas, sob temperatura de extrusão de $75^{\circ} \mathrm{C}$ e rotação de $230 \mathrm{rpm}$ 


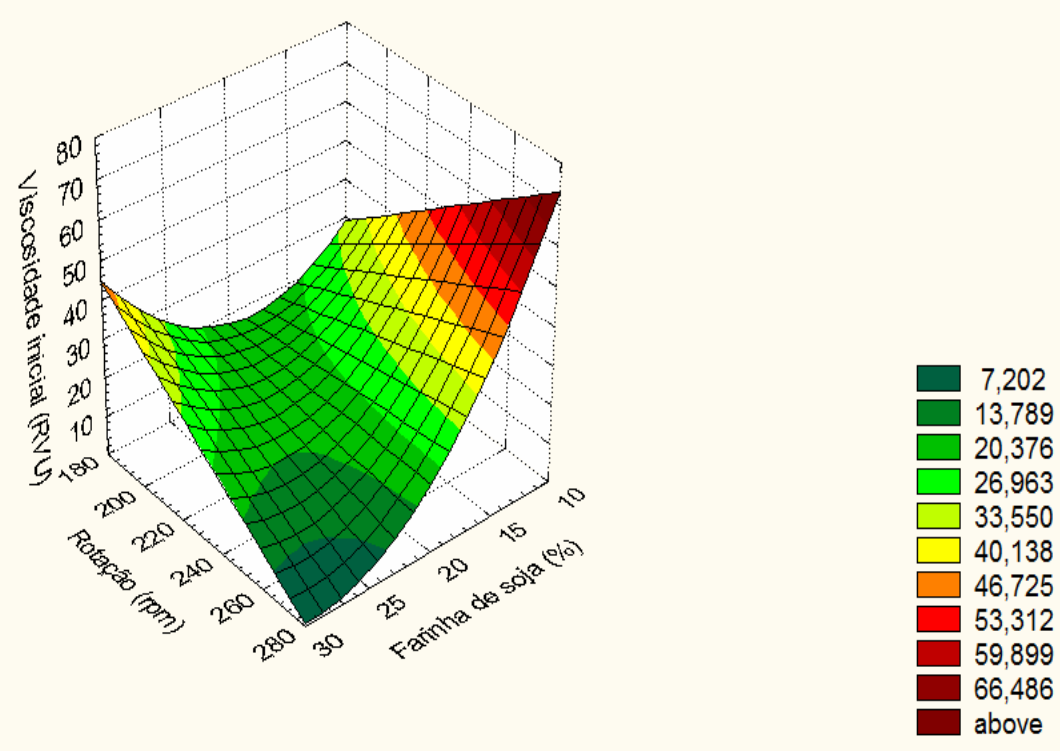

Figura 13 - Efeito da porcentagem de farinha de soja na mistura e da rotação da rosca sobre a viscosidade inicial das misturas extrusadas, sob temperatura de extrusão de $75^{\circ} \mathrm{C}$ e $20 \%$ de farelo de mandioca na mistura.

Segundo Menegassi et al. (2007), os valores de viscosidade inicial se elevam com a prévia gelatinização da amostra e decrescem em condições severas de processamento em razão da despolimerização do amido com a cocção.

\subsubsection{Pico de viscosidade (PV)}

Este parâmetro se refere ao pico de viscosidade após o início do aquecimento e antes do início do resfriamento da suspensão no viscoamilógrafo.

Os resultados obtidos para o pico de viscosidade (PV) dos produtos extrusados nas diferentes condições de processo variam de 14,5 a 114,92 RVU (Tabela 20). A análise dos coeficientes de regressão mostrou ter havido influência significativa do teor de farinha de soja e da rotação (Tabela 22). 
Tabela 22 - Coeficientes de regressão estimados e ANOVA para o pico de viscosidade das misturas extrusadas.

\begin{tabular}{|c|c|c|c|c|c|c|}
\hline & & \multicolumn{2}{|c|}{$\begin{array}{l}\text { Coeficientes de } \\
\text { regressão }\end{array}$} & Erro padrão & GL & $p$ valor \\
\hline Média & \multicolumn{3}{|c|}{25,19} & & & \\
\hline Farinha de soja (I & \multicolumn{3}{|c|}{$-7,003$} & 2,9924 & 1 & 0,0272 \\
\hline Rotação (L) & \multicolumn{3}{|c|}{$-8,3300$} & 2,9924 & 1 & 0,0099 \\
\hline Rotação (Q) & \multicolumn{3}{|c|}{8,4167} & 2,7317 & 1 & 0,0048 \\
\hline $\mathrm{R}^{2}$ & \multicolumn{3}{|c|}{0,4663} & & & \\
\hline \multicolumn{7}{|l|}{ ANOVA } \\
\hline & GL & SQ & QM & $\mathrm{F}_{\text {calculado }}$ & $\mathrm{F}_{\text {tabelado }}$ & $\operatorname{Pr}>F$ \\
\hline Regressão & 3 & 4882,65 & 1627,55 & 7,57 & 3,37 & 0,0008 \\
\hline Resíduos & 26 & 5587,50 & 214,90 & & & \\
\hline Total & 29 & 10470,15 & & & & \\
\hline
\end{tabular}

Nas condições intermediárias de farinha de soja e farelo de mandioca e elevada rotação da rosca são observados os menores picos de viscosidade de acordo com a superfície de resposta traçada a partir do modelo ajustado (Figura 14).

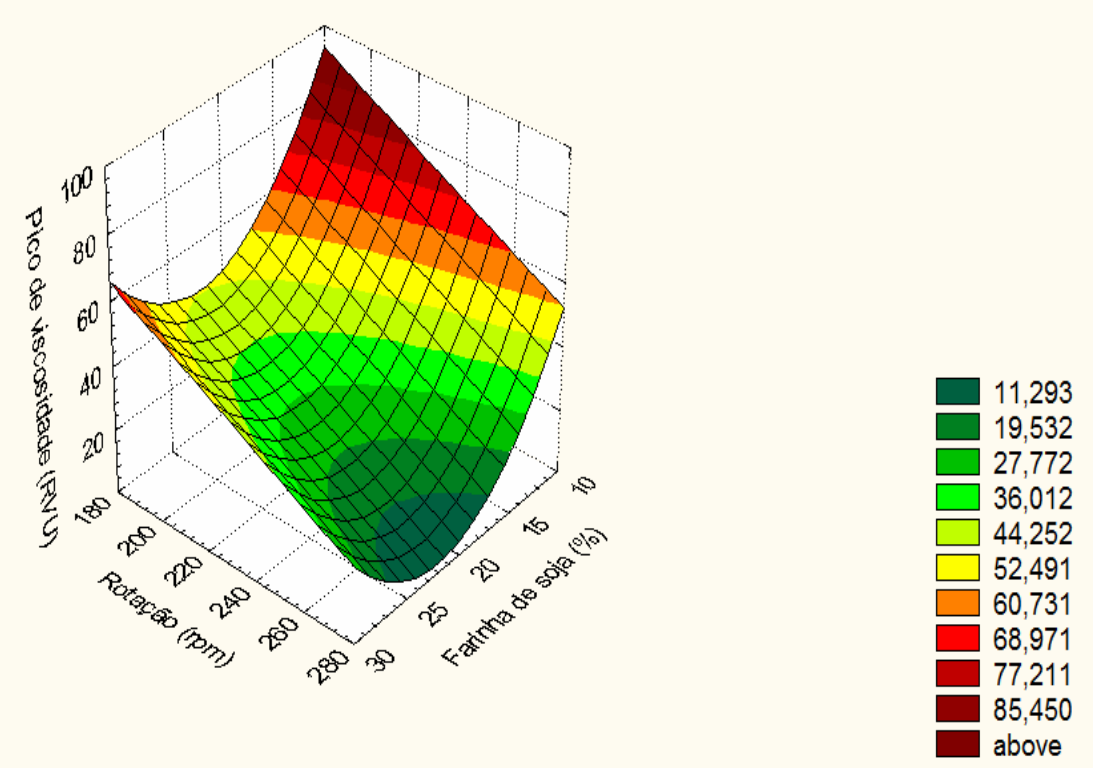

Figura 14 - Efeito da porcentagem de farinha de soja na mistura e da rotação da rosca sobre o pico de viscosidade das misturas extrusadas, sob temperatura de extrusão de $75^{\circ} \mathrm{C}$ e $20 \%$ de farelo de mandioca na mistura. 
Pesquisas realizadas por El-Said et al., (1979), constataram que o conteúdo de proteína é negativamente correlacionado com a viscosidade máxima. A proteína pode atuar como uma barreira física para o intumescimento do amido, uma vez que os grânulos de amido são encaixados na matriz de proteína. Dessa forma, observa-se que, mistura contendo maiores teores de proteína presente na farinha de soja, resultam em menor pico de viscosidade.

Lira Filho (2001), estudou os efeitos de diferentes temperaturas de extrusão $\left(116,130,150,170\right.$ e $\left.184^{\circ} \mathrm{C}\right)$, a porcentagem de umidade $(18,20,23$ e $26 \%$ ) e a rotação do parafuso do extrusor $(106,120,140,160$ e $174 \mathrm{rpm})$ sobre o percentual protéico de farinha integral de feijão caupi, concluiu que os resultados dos teores protéicos não variaram entre os tratamentos.

\subsubsection{Quebra de viscosidade $(Q V)$}

A quebra de viscosidade representa a diferença entre o pico de viscosidade e o menor valor de viscosidade após o pico no perfil amilográfico. Através desta propriedade é possível avaliar a estabilidade em altas temperaturas, sob agitação mecânica.

De acordo com os resultados pode-se observar que a quebra de viscosidade (QV) variou de 8,75 a 108,42 RVU (Tabela 20). A análise dos coeficientes de regressão mostrou terem ocorrido efeitos significativos da rotação e do teor de farinha de soja (Tabela 23). Menores valores de quebra de viscosidade são observados nas condições intermediárias de farinha de soja e elevada rotação (Figura 15). 
Tabela 23 - Coeficientes de regressão estimados e ANOVA para a quebra de viscosidade das misturas extrusadas.

\begin{tabular}{|c|c|c|c|c|c|c|}
\hline & & $\begin{array}{r}\text { Coefic } \\
\text { reg }\end{array}$ & $\begin{array}{l}\text { tes de } \\
\text { são }\end{array}$ & Erro padrão & GL & $p$ valor \\
\hline Média & & & & & & \\
\hline Farinha de $s$ & & & & 2,969 & 1 & 0,0293 \\
\hline Rotação (L) & & & & 2,969 & 1 & 0,0095 \\
\hline Rotação (Q) & & & & 2,710 & 1 & 0,0038 \\
\hline $\mathrm{R}^{2}$ & & & & & & \\
\hline ANOVA & & & & & & \\
\hline & GL & SQ & QM & $\mathrm{F}_{\text {calculado }}$ & $\mathrm{F}_{\text {tabelado }}$ & $\operatorname{Pr}>\mathrm{F}$ \\
\hline Regressão & 3 & 4927,72 & 1642,57 & 7,76 & 3,37 & 0,0007 \\
\hline Resíduos & 26 & 5500,79 & 211,57 & & & \\
\hline Total & 29 & 10428,51 & & & & \\
\hline
\end{tabular}

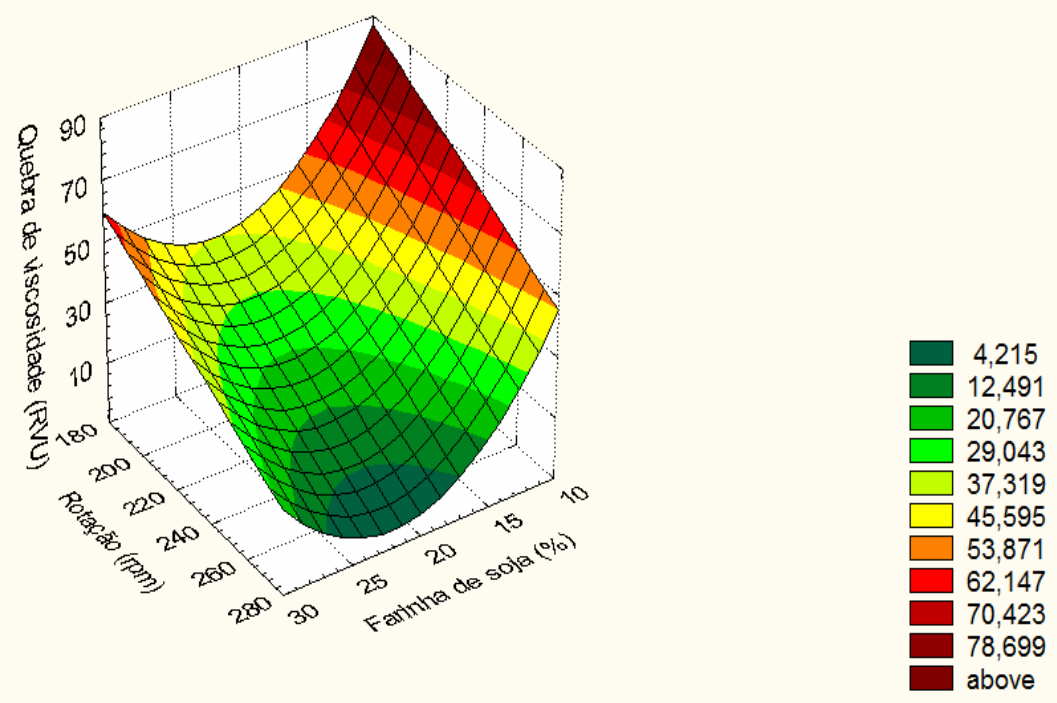

Figura 15 - Efeito da porcentagem de farinha de soja na mistura e da rotação da rosca sobre a quebra de viscosidade das misturas extrusadas, sob temperatura de extrusão de $75^{\circ} \mathrm{C}$ e $20 \%$ de farelo de mandioca na mistura. 


\subsubsection{Viscosidade final (VF)}

A viscosidade final (VF) é uma característica, que em produtos extrusados, vai depender das modificações que ocorrem nas estruturas do grânulo de amido e das moléculas durante o processamento.

A viscosidade final das misturas extrusadas variou de 6,25 a 15,42 RVU (Tabela 20). Considerando a variação observada, a análise de regressão mostrou terem ocorrido efeitos significativos dos teores de farelo de mandioca e farinha de soja, bem como da interação farinha de soja e rotação (Tabela 24).

Valores superiores aos obtidos neste trabalho foram verificados por Bhattacharya et al. (1999) que observaram viscosidade final em misturas de farinha de trigo e batata após a extrusão variando a VF entre 18 a 11 RVU, nas diferentes condições empregadas.

Tabela 24 - Coeficientes de regressão estimados e ANOVA para a viscosidade final das misturas extrusadas (modelo ajustado).

\begin{tabular}{|c|c|c|c|c|c|c|}
\hline & & \multicolumn{2}{|c|}{$\begin{array}{l}\text { Coeficientes de } \\
\text { regressão }\end{array}$} & Erro padrão & GL & $p$ valor \\
\hline Média & & \multicolumn{2}{|c|}{8,23} & & & \\
\hline Farelo de $n$ & (L) & \multicolumn{2}{|c|}{$-0,87$} & 0,4354 & 1 & 0,0563 \\
\hline Farinha de & & \multicolumn{2}{|c|}{$-1,11$} & 0,4354 & 1 & 0,0168 \\
\hline Farelo de $n$ & (Q) & \multicolumn{2}{|c|}{0,85} & 0,3974 & 1 & 0,0421 \\
\hline $\begin{array}{l}\text { Farinha de } \\
\mathrm{R}^{2}\end{array}$ & ação & \multicolumn{2}{|c|}{$-1,02$} & 0,5332 & 1 & 0,0684 \\
\hline \multicolumn{7}{|l|}{ ANOVA } \\
\hline & GL & SQ & QM & $F_{\text {calculado }}$ & $\mathrm{F}_{\text {tabelado }}$ & $\operatorname{Pr}>F$ \\
\hline Regressão & 4 & 85,4677 & 21,37 & 4,70 & 2,76 & 0,0058 \\
\hline Resíduos & 25 & 113,73 & 4,55 & & & \\
\hline Total & 29 & 199,20 & & & & \\
\hline
\end{tabular}

Analisando a Figura 16, observou-se que os menores valores de VF foram obtidos com o aumento da rotação e da farinha de soja. Maiores viscosidades finais são obtidas nas condições de menores porcentagens de farelo de mandioca e farinha de soja nas misturas, evidenciando a influência do teor de proteína e fibras sobre as propriedades de pasta antes e após a extrusão (Figura 17). 


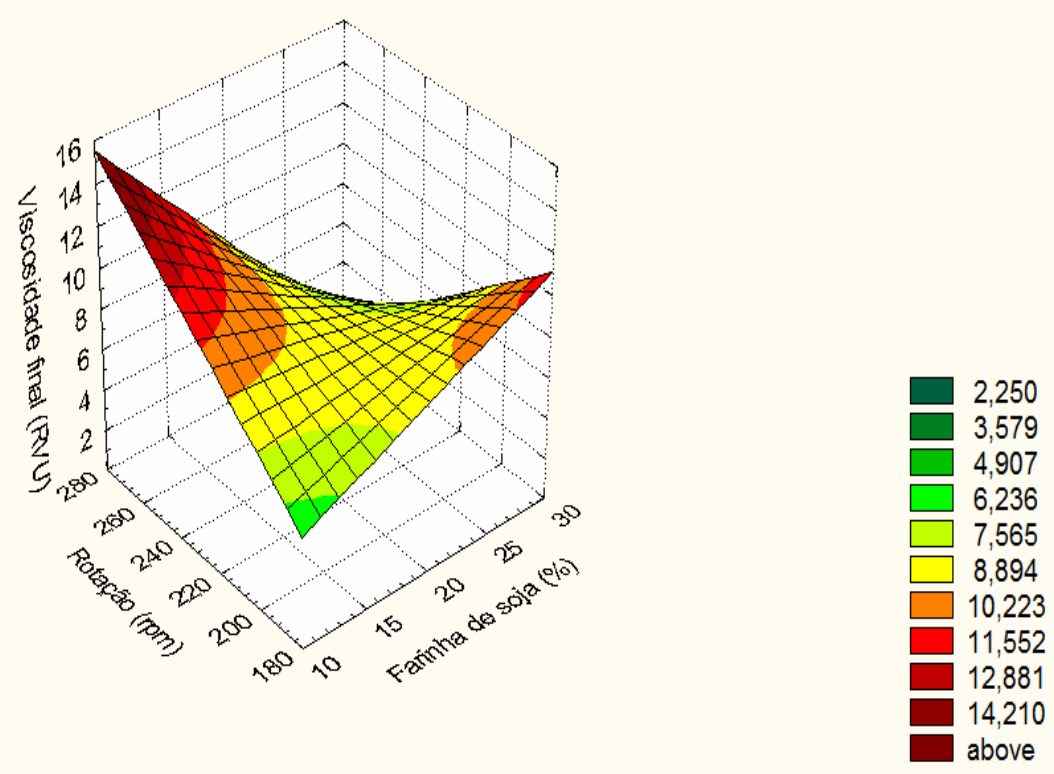

Figura 16 - Efeito da porcentagem de farinha de soja na mistura e da rotação da rosca sobre a viscosidade final das misturas extrusadas, sob temperatura de extrusão de $75^{\circ} \mathrm{C}$ e $20 \%$ de farelo de mandioca na mistura.

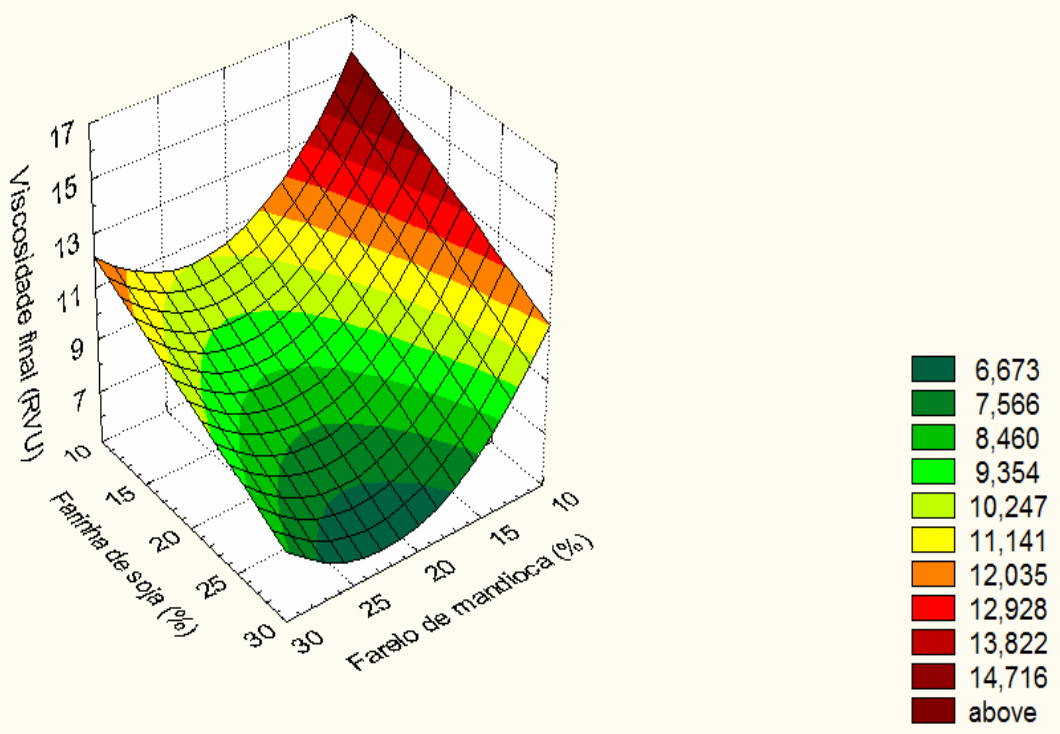

Figura 17 - Efeito da porcentagem de farinha de soja e farelo de mandioca na mistura sobre a viscosidade final das misturas extrusadas, sob temperatura de extrusão de $75^{\circ} \mathrm{C}$ e rotação de $230 \mathrm{rpm}$. 


\subsubsection{Tendência a retrogradação (TR)}

Os valores da tendência a retrogradação (TR) dos produtos extrusados variaram de 0 a 7,59 RVU (Tabela 20). A análise dos coeficientes de regressão mostrou que dentre os parâmetros variáveis estudados apenas a temperatura de extrusão não teve efeito significativo sobre esta propriedade de pasta (Tabela 25).

Tabela 25 - Coeficientes de regressão estimados e ANOVA para a tendência a retrogradação das misturas extrusadas (modelo ajustado).

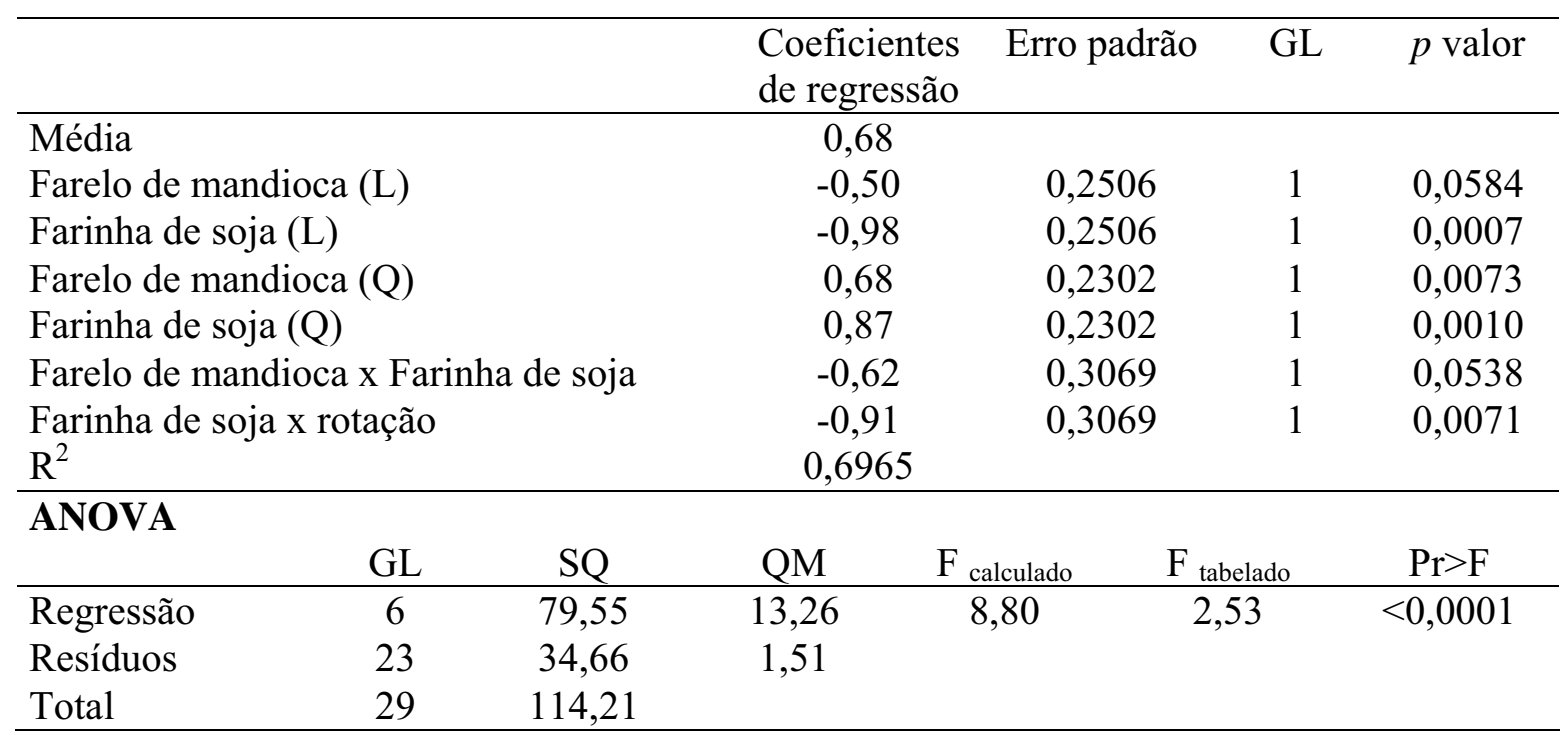

A retrogradação do amido ocorre por efeito da recristalização das moléculas de amilose e amilopectina, decorrente do agrupamento das partes lineares das moléculas de amido através da formação de novas ligações de hidrogênio, resultando na formação de precipitados e/ou géis (GUTKOSKI \& EL-DASH, 1990).

A tendência a retrogradação é menor nas condições de maiores porcentagens de farelo e farinha de soja na mistura (Figura 18).

Hibi (1994) constatou que a formação de um complexo helicoidal insolúvel entre amilose e lipídio resulta num retardamento da lixiviação da amilose dos grânulos e consequentemente, uma menor retrogradação. Acredita-se, portanto, que a 
diminuição no teor de amido (especialmente no de amilose) e/ou aumento no conteúdo de lipídio tenham contribuído para o decréscimo da retrogradação.

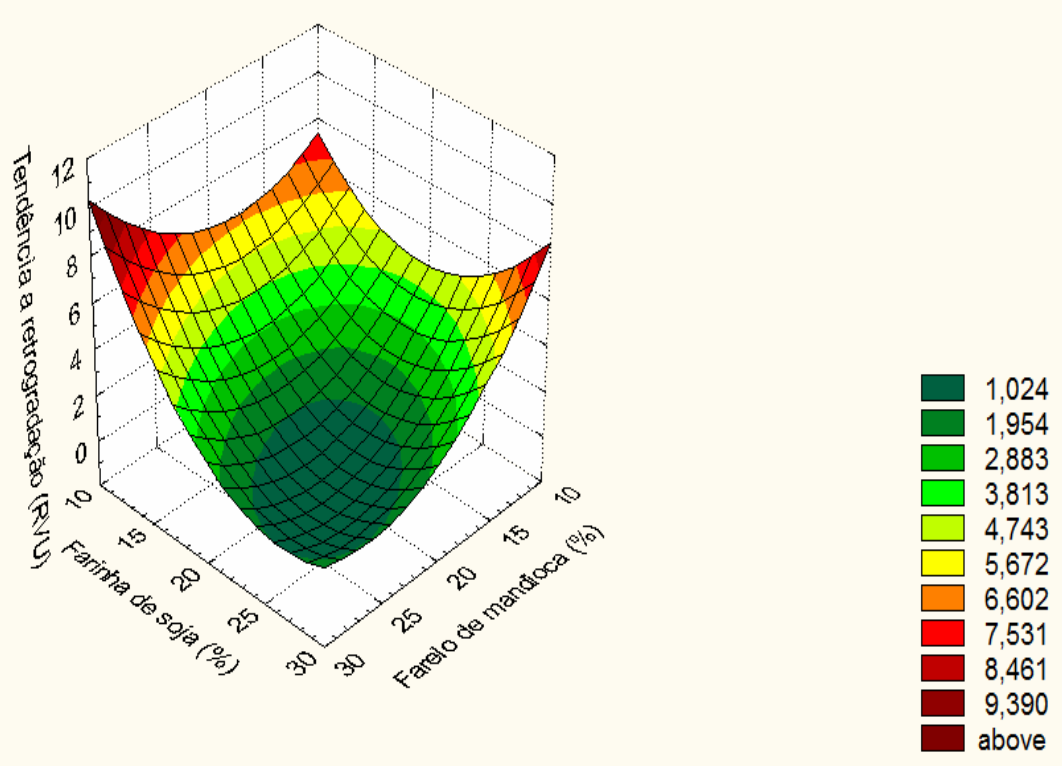

Figura 18- Efeito da porcentagem de farinha de soja e farelo de mandioca na mistura sobre a tendência a retrogradação das misturas extrusadas.

\subsection{Propriedades térmicas}

As farinhas extrusadas nos diferentes tratamentos não mostraram entalpia de gelatinização residual sugerindo que todo o amido presente nas amostras foi gelatinizado (Figura 19). Portanto, as diferenças observadas entre os tratamentos nas propriedades de pasta não são devidas à presença de grânulos intactos. 


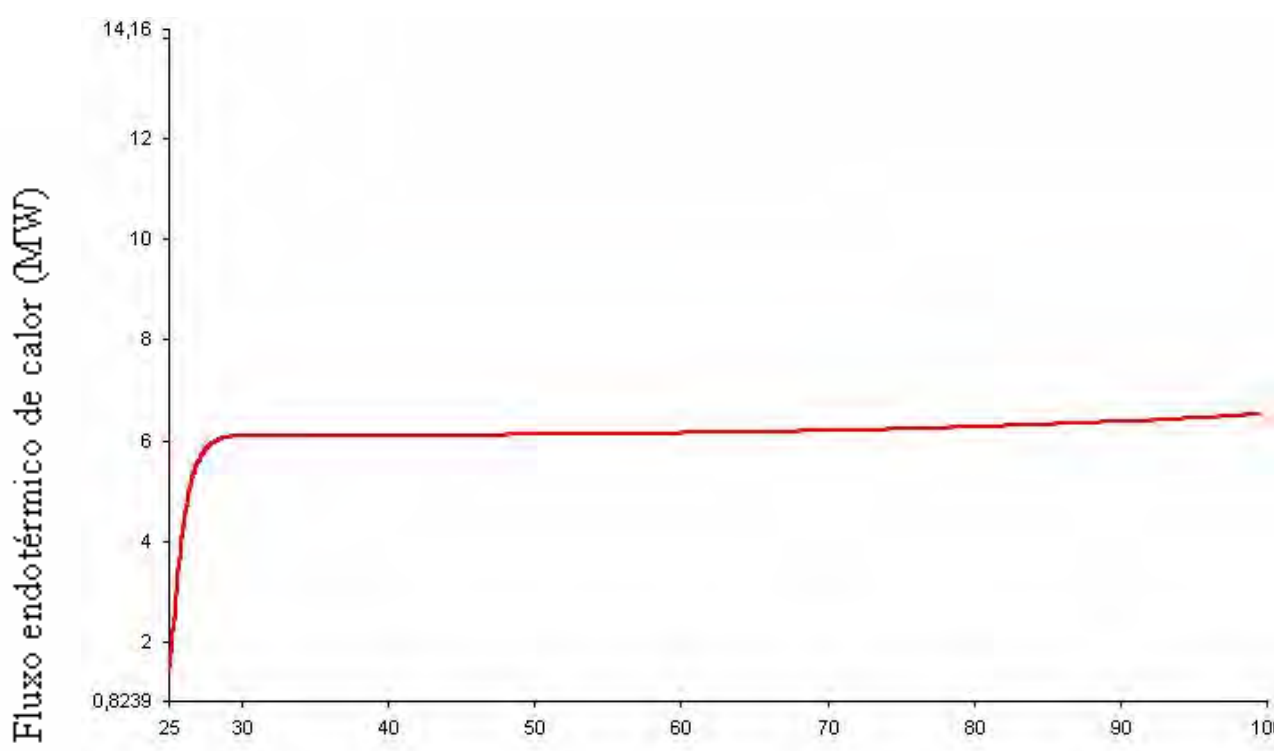

Temperatura $\left({ }^{\circ} \mathrm{C}\right)$

Figura 19- Perfil endotérmico observado por DSC da farinha extrusada nas condições centrais dos parâmetros variáveis.

\subsection{Amido resistente nas misturas extrusadas}

A Tabela 26 apresenta o teor de amido resistente nas misturas extrusadas, nas diferentes condições experimentais, onde se observou-se uma variação de 0,33 a $1,42 \%$. Verificou-se que após o processo de extrusão ocorreu redução no teor de amido resistente, quando comparado com as misturas antes da extrusão variando de 2,65 a 1,23\% (Tabela 9).

A condição experimental em que se observou o maior teor de amido resistente na mistura extrusada foi aquela em que se tinha $25 \%$ de farelo de mandioca e $15 \%$ de farinha de soja na mistura com a fécula, temperatura de extrusão de $60^{\circ} \mathrm{C}$ e $250 \mathrm{rpm}$ de rotação da rosca (tratamento 10). 
Tabela 26- Resultados médios encontrados para o teor de amido resistente nas misturas extrusadas sob as diferentes condições experimentais.

\begin{tabular}{|c|c|c|c|c|c|c|c|c|c|}
\hline \multirow[b]{2}{*}{ Trat. } & \multicolumn{4}{|c|}{$\begin{array}{c}\text { Níveis } \\
\text { codificados }\end{array}$} & \multicolumn{4}{|c|}{$\begin{array}{c}\text { Variáveis } \\
\text { independentes }\end{array}$} & \multirow{2}{*}{$\begin{array}{c}\begin{array}{c}\text { Variável } \\
\text { dependente }\end{array} \\
\text { AR (\%) }\end{array}$} \\
\hline & X1 & $\mathrm{X} 2$ & $\mathbf{X 3}$ & $\mathrm{X4}$ & FM & FS & $\mathbf{T}$ & $\mathbf{R}$ & \\
\hline 1 & -1 & -1 & -1 & -1 & 15 & 15 & 60 & 210 & 0,94 \\
\hline 2 & 1 & -1 & -1 & -1 & 25 & 15 & 60 & 210 & 1,02 \\
\hline 3 & -1 & 1 & -1 & -1 & 15 & 25 & 60 & 210 & 1,12 \\
\hline 4 & 1 & 1 & -1 & -1 & 25 & 25 & 60 & 210 & 0,50 \\
\hline 5 & -1 & -1 & 1 & -1 & 15 & 15 & 90 & 210 & 0,91 \\
\hline 6 & 1 & -1 & 1 & -1 & 25 & 15 & 90 & 210 & 0,98 \\
\hline 7 & -1 & 1 & 1 & -1 & 15 & 25 & 90 & 210 & 1,17 \\
\hline 8 & 1 & 1 & 1 & -1 & 25 & 25 & 90 & 210 & 0,71 \\
\hline 9 & -1 & -1 & -1 & 1 & 15 & 15 & 60 & 250 & 0,73 \\
\hline 10 & 1 & -1 & -1 & 1 & 25 & 15 & 60 & 250 & 1,42 \\
\hline 11 & -1 & 1 & -1 & 1 & 15 & 25 & 60 & 250 & 1,20 \\
\hline 12 & 1 & 1 & -1 & 1 & 25 & 25 & 60 & 250 & 0,79 \\
\hline 13 & -1 & -1 & 1 & 1 & 15 & 15 & 90 & 250 & 0,90 \\
\hline 14 & 1 & -1 & 1 & 1 & 25 & 15 & 90 & 250 & 0,97 \\
\hline 15 & -1 & 1 & 1 & 1 & 15 & 25 & 90 & 250 & 1,14 \\
\hline 16 & 1 & 1 & 1 & 1 & 25 & 25 & 90 & 250 & 0,71 \\
\hline 17 & -2 & 0 & 0 & 0 & 10 & 20 & 75 & 230 & 1,00 \\
\hline 18 & 2 & 0 & 0 & 0 & 30 & 20 & 75 & 230 & 1,02 \\
\hline 19 & 0 & -2 & 0 & 0 & 20 & 10 & 75 & 230 & 0,71 \\
\hline 20 & 0 & 2 & 0 & 0 & 20 & 30 & 75 & 230 & 0,54 \\
\hline 21 & 0 & 0 & -2 & 0 & 20 & 20 & 45 & 230 & 0,44 \\
\hline 22 & 0 & 0 & 2 & 0 & 20 & 20 & 105 & 230 & 0,51 \\
\hline 23 & 0 & 0 & 0 & -2 & 20 & 20 & 75 & 190 & 0,44 \\
\hline 24 & 0 & 0 & 0 & 2 & 20 & 20 & 75 & 270 & 0,33 \\
\hline 25 & 0 & 0 & 0 & 0 & 20 & 20 & 75 & 230 & 0,52 \\
\hline
\end{tabular}

X1: farelo de mandioca (\%); X2: farinha de soja (\%); X3: temperatura na $3^{\mathrm{a}}$ zona do extrusor $\left({ }^{\circ} \mathrm{C}\right) ; \mathrm{X} 4$ : rotação da rosca $(\mathrm{rpm}) ; \mathrm{AR}=$ amido resistente $(\%)$.

Freitas \& Leonel (2009), avaliando o efeito de parâmetros operacionais de extrusão sobre o teor de amido resistente em fécula de mandioca, observaram uma variação de 0,9 a 2,14\%, com queda acentuada do teor de amido resistente nas féculas extrusadas a partir da temperatura de $60^{\circ} \mathrm{C}$.

O cozimento por extrusão, em geral, aumenta significativamente a digestibilidade de amido extrusados quando comparados com os não extrusados, devido à ruptura da estrutura física do grânulo de amido e a gelatinização, caracterizados pelo aumento da viscosidade a frio (HAGENIMANA et al., 2006). 
Os grânulos de amido são rompidos pela energia térmica e mecânica no processo de extrusão, aumentando a acessibilidade das amilases. Após o resfriamento, as cadeias hidratadas de amilose e amilopectina sofrem um processo de re-associação molecular e, conseqüentemente, podem adquirir resistência à digestão enzimática (HTOON et al., 2009).

A partir dos resultados foi obtido o modelo matemático que prediz o comportamento das variáveis estudas quanto à presença de amido resistente nos produtos (Tabela 27).

Tabela 27- Coeficientes de regressão estimados e ANOVA para o amido resistente das misturas extrusadas (modelo ajustado).

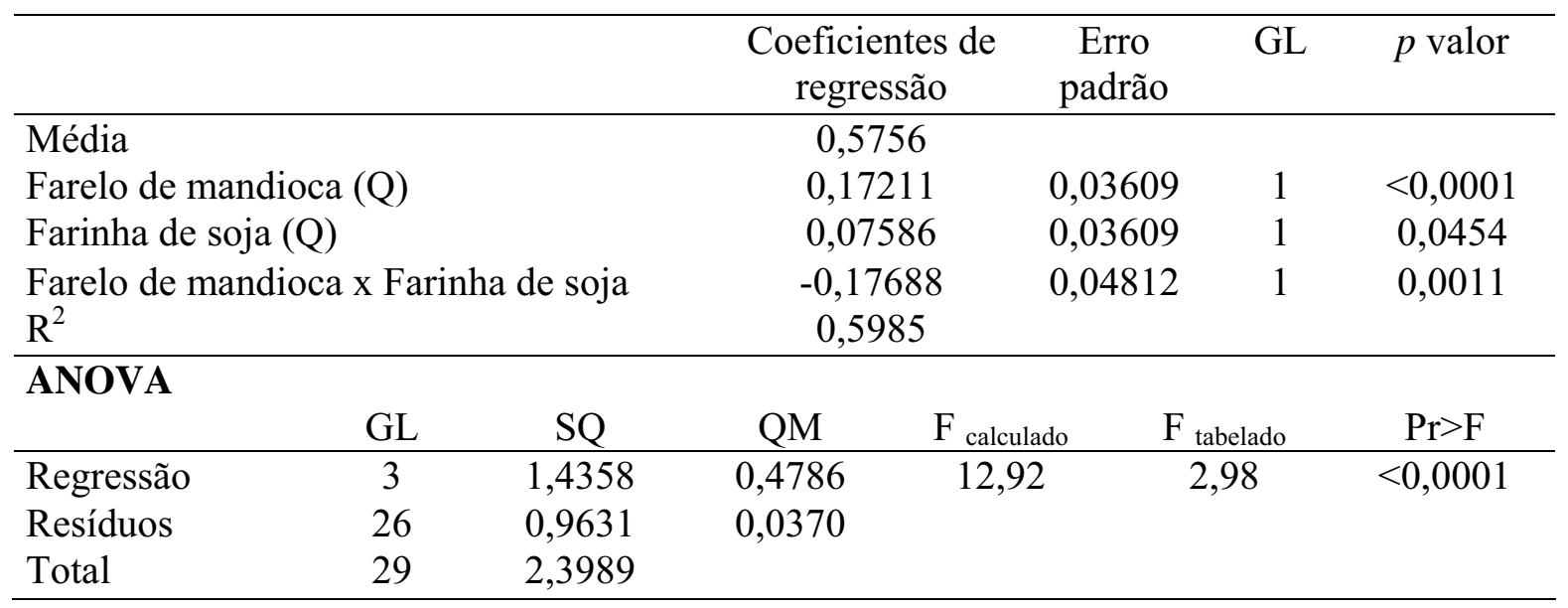

A análise dos coeficientes de regressão mostrou ter ocorrido influência significativa dos teores de farelo de mandioca e farinha de soja na mistura com fécula de mandioca sobre o teor de amido resistente das farinhas extrusadas. A partir do modelo ajustado obtido foi possível a construção do gráfico de superfície de resposta que permite visualizar as melhores condições para a variável independente do amido resistente (Figura 20).

A superfície de resposta traçada evidencia que nas condições de elevada porcentagem de farelo de mandioca e menor porcentagem de farinha de soja, bem como, nas situações inversas são encontrados os maiores teores de amido resistente nas misturas extrusadas. 


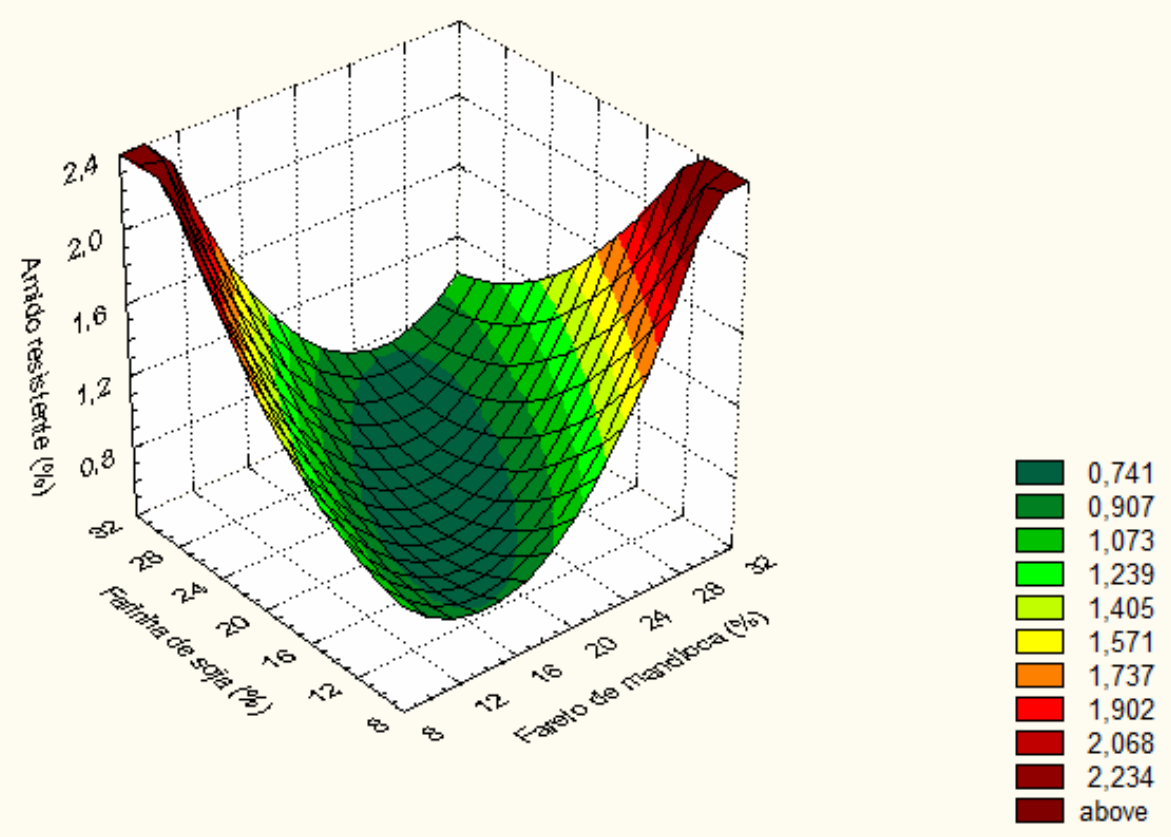

Figura 20 - Efeito da porcentagem de farinha de soja e farelo de mandioca na mistura sobre o teor de amido resistente nas misturas extrusadas, sob temperatura de extrusão de $75^{\circ} \mathrm{C}$ e rotação de 230rpm. 


\section{CONCLUSÕES}

Os resultados obtidos nesse trabalho permitem concluir que:

- As condições de elevada temperatura de extrusão $\left(90-105^{\circ} \mathrm{C}\right)$ e rotação da rosca $(270$ $\mathrm{rpm})$ com as porcentagens intermediárias de farelo de mandioca $(20 \%)$ e baixa porcentagem de farinha de soja (10\%) misturados á fécula de mandioca propiciam produtos com maior expansão;

- Farinhas extrusadas claras, com considerável absorção de água, baixa solubilidade, elevada viscosidade inicial e maior teor de amido resistente, parâmetros de interesse para o uso como farinha instantânea funcional são obtidas nas condições de: menores porcentagens de farelo de mandioca e farinha de soja (10\%) misturados á fécula de mandioca; elevada temperatura de extrusão $\left(90-105^{\circ} \mathrm{C}\right)$ e elevada rotação da rosca (270rpm). 


\section{REFERÊNCIAS BIBLIOGRÁFICAS}

ALVES, R.M.L., GROSSMANN, M.V.E. Parâmetros de extrusão para produção de "snacks" de farinha de cará (Dioscorea alata). Ciência e Tecnologia de Alimentos, Campinas, v.22, n.1, p.32-38, jan/abr., 2002.

ALVIM, I.D., SGARBIERI,V.C., CHANG, Y.K. Desenvolvimento de farinhas mistas extrusadas à basede farinha de milho, derivados de levedura e caseína. Revista de Ciência e Tecnologia de Alimentos, p.170-176, 2002.

AMERICAN ASSOCIATION OF CEREAL CHEMISTS. Approved Methods Of The American Association Of Cereal Chemists. St. Paul, 1975.

ANDERSON R. A.; CONWAY, V. F.P.; GRIFFIN , E. L. Gelatinization of corn grits by rolland extrusion-cooking. Cereal Science Today, v.14, n.1, p.4-7, jan.1969. 
Analysis of the Association of Official Analytical Chemists. 12 ${ }^{\mathrm{a}}$ ed, Washington, 1975. 1094 p.

BARROS NETO, B.; SCARMÍNIO, I. S.; BRUNS, R. E. Como fazer experimentos: pesquisa e desenvolvimento na ciência e na indústria. $2^{\circ}$ ed. Campinas: Editora UNICAMP, 2003, p. 401

BAZINET, L.; LAMARCHE, R.; TOUPIN, R.; BOULET, M.; IPPERSIELL, D.

Electroacidification of soybean for production of isolate. Food Technology, Chicago, v. 51, n. 9, p. 52-60, 1997.

BRASIL. Leis, Decretos, etc. Decreto n 986 de 21 de outubro de 1978. Normas técnicas especiais relativas a alimentos (e bebidas). Diário Oficial do Estado de São Paulo, 24/07/1978. Disponível em:http://www.anvisa.gov.br/legis/resol/12_78_amidos.htm>. Acesso 12 outubro 2009.

BRASIL. Resolução n ${ }^{\circ}$ 12/78 da Comissão Nacional de Normas e Padrões para Alimentos. Aprova as normas técnicas especiais do Estado de São Paulo, revistas pela CNNPA, relativas a alimentos (e bebidas). Diário Oficial da República Federativa do Brasil, Poder Executivo, Brasília, 24 de julho de 1978. Seção 1. Parte 1. Disponível em: <http://: www.anvisa.org.br.htm>. Acesso em ago. de 2008.

BRASIL. Ministério da Saúde. Resolução nº 18/99. ANVISA. Alimentos com Alegações de Propriedades Funcionais e ou de Saúde, Novos Alimentos/Ingredientes, Substâncias Bioativas e Probióticos. IX - Lista de alegações de propriedade funcional aprovadas. Diário Oficial do Estado de São Paulo, 2009. Disponível em: <http://: www.anvisa.org.br.htm>. Acesso em 27 de fev. 2010.

BRASIL. Ministério da Saúde. Portaria 31/98 da ANVISA. Regulamento Técnico para Fixação de Identidade e Qualidade de Alimentos Adicionados de Nutrientes Essenciais.

Diário Oficial (da) República Federativa do Brasil, Brasília, DF, ano 30, mar. 1998. Seção 
I-E, p.4. Disponivel em: <http://www.Anvisa.gov.Br/legis/portarias/31_98.htm>. Acesso em 18 janeiro. 2010.

BHATTACHARYA, S.; SUDHA, M. L.; RABIN, A. Pasting characteristics of an extruded blend of potato and wheat. Journal of Food Engineering, Essex, v. 40, p. 107-111, 1999.

BERGLUND, P. T.; FASTNAUGHT, C. E.; HOLM, E. T. Physicochemical and sensory evaluation of extruded high-fiber barley cereals. Cereal Chemistry, St. Paul: American Association of Cereal Chemists, v. 71, nº 1, p. 91-95, Jan-Feb. 1994.

BLENNOW, A. et al. The distribution of covalently bound phosphate in starch granule in relation to starch crystallinity. International Journal of Biological Macromolecules, v. 27, p. 211-218, 2000.

BORBA, A. M. Efeitos de alguns parâmetros operacionais nas características físicoquímicas e funcionais de extrusados da farinha de batata-doce (Ipomoea batatas). Piracicaba, 2005. 98p. Dissertação (Mestrado) - Faculdade de Engenharia de Alimentos, Universidade Estadual de Campinas.

BORGES, G. G.; WNAG, S. H.; CABRAL, L. C.; ASCHERI, J. L. R.; MAIA, L. H. Viscosidad de pasta, absorcion de água y absorción de grasa de gachas deshidratadas eleboradas com maiz y soja. Alimentaria, Madrid, v. 35, n. 295, p. 63-66, 1998.

BOMBO, A.J. Obtenção e caracterização nutricional de snacks de milho (Zea mays L.) e linhaça (Linum usitatissimum L.). São Paulo, 2006. 96p. Dissertação (mestrado). Faculdade de Saúde Púlica, Universidade de São Paulo.

BOX, G. E. P.; WETZ, J. Criteria for judging adequacy of estimation by an approximate response function. University of Wisconsin Technical Report, Madison, n. 9, 1973 
BULÉON, A. P. COLONNA, V. PLANCHOT, S. BALL. Starch granules: structure and biosynthesis. International Journal of Biological Macromolecules, v. 23, p. 85-112, 1998.

CAMBRODON, I. G. MARTIN-CARRON, N. Fermetación colónica de fibra dietética y almidón resistente. In: LAJOLO, F M. et al. Fibra dietética en Iberoamérica. Tecnologia y salud-obtención, caracterización, efecto fisiologico y aplicación en alimentos. São Paulo:Varela, 2001. 469 p.

CAMIRE, M. E.; CAMIRE, A.; KRUMHAR, K. Chemical and nutritional changes in foods during extrusion. Critical Reviews in Food Science and Nutrition, v. 19, p. 35-57, 1990.

CARVALHO, R.V. Formulações de snacks de terceira geração por extrusão: caracterização texturométrica e microestrutural. Lavras (MG), 89 p., 2000. Dissertação (mestrado em Ciência dos Alimentos) - Universidade Federal de Lavras.

CARVALHO, R. V.; ASCHERI, J. L. R.; CAL-VIDAL, J. Efeito dos parâmetros de extrusão nas propriedades físicas de extrusados $(3 \mathrm{G})$ de misturas de farinhas de trigo, arroz e banana. Ciência e Agrotecnologia, v.26, n.5, p.1006-1018, set./out. 2002.

CHANG, Y. K.; HASHIMOTO, J. M.; ACIOLI-MOURA, R.; MARTÍNEZ-FLORES, H. E.; MARTÍNEZ-BUSTOS, F. Influence of extrusion condition on cassava starch and soybean protein concentrate blends. Acta Alimentaria, v. 30, n. 2, p. 189-203, 2001

CHARALAMPOPOULOS, R.; WANG, S.S.; PANDIELLA, C.; WEBB, C.Application of cereals and cereal components in functional foods: a review. International Journal of Food Microbiology, v.79, p.131-141. 2002.

CHAUHAN, G. S.; BAINS, G. S. Effect of defatted soy flour on the physico-chemical characteristics of extruded rice products. Journal of Food Science and Technology v. 22, n. 2, p. 115-118, 1985. 
CHANG, Y. K.; EL-DASH, A. A. Effects of acid concentration and extrusion variables on some phisical characteristics and energy requirements of cassava starch. Brazilian Journal of Chemical Engeneering, São Paulo, v. 20, n. 2, p. 129-137, 2003.

CEREDA, M. P. Caracterização dos resíduos da industrialização da mandioca. In:

Resíduos da industrialização da mandioca no Brasil. São Paulo: Paulicéia, 1994. cap. 1, p. $11-50$.

COLONNA, P. et al. Extrusion cooking and drum drying of wheat starch. I. Physical and macromolecular modifications. Cereal Chemistry., v. 61, n. 6, p. 538-543, 1984.

CHEFTEL, J. C. Nutritional effects of extrusion cooking. Food chemistry, v.20, n.3, p.263283, 1986.

CHRISTOFIDES, V.; AINSWORTH, P.; IBANOGLU, S.; GOMES, F. Physical evaluation of maize-based extruded sanck with curry powder. Nahrung, v.48, n.1, p.61-64, 2004.

COCHRAN, W.G. \& COX, G.M. Experimental designs. 2.ed. London, John Wiley, 1957. $611 \mathrm{p}$.

CHUNG, T. K. et al. Physicochemical properties of soybean oil extracted from-irradiated soybeans. Radiation Physics and Chemistry., v. 46, n. 4-6, p. 659-662, 1996.

DING, Q.; AINSWOTH, P.; TUCKER, G.; MARSON, H. The effect of extrusion conditions on the physicochemical properties and sensory characteristics of rice based expanded snacks. Journal of Food Engineering, v.66, p.283-289, 2005.

EERLINGER, R. C.; DELCOUR, J.A. Formation, analysis, structure and properties of type III enzyme resistant starch. Journal of Cereal Science, Heverlee, Belgium. v. 22, p. 129-138, 1995. 
EL-DASH, A.A. Aplication and control of thermoplastic extrusion of cereals for food and industrial uses. In: POMERANZ, Y.; MUNCH, L. Cereals a renewable resource: theory and pratice. St. Paul: AACC, 1982. CAP.10, P.165-216.

EL-SAIED, H. M.; AHMED, E.A.; ROUSHDI, M.; EL-ATTAR, W. Gelatinization, pasting characteristics and cooking behavior of Egyptian rice varieties in relation to amylose and proteins contents. Starch/Stärke, New York, v. 31, n. 8, p. 270-274, 1979.

ENGLYST, H.N.;KINGMAN, S.M.; Classification and measurement of nutritionally important starch fractions. Eur J Clin Nutr, v.46, p.S33-S50, 1992.

FAOSTAT. Food and Agriculture Organization of the United Nations. Production estatística, 2008. Disponível em: <http://www.faostat.fao.org.htm>. Acesso em: 23 de fev. 2010.

FAUBION, J.M.; HOSENEY, R.C.; SEIB, P.A. Functionality of grain compounds in extrusion. Cereal Foods World, v.27, n.5, p.212-216, 1982.

FELLOWS, P. Extrusion. In: FELLOWS, P. Food processing technology: principles and practive. Cambridge: Woodhead Publishing, 2002. cap.14, p.294-308.

FERREIRA,T.A.P.C. Avaliação nutricional do amaranto (Amaranthus caudatus L.) extrusado em diferentes condições de umidade. São Paulo, 1999. 157p. Tese (Doutorado) Faculdade de Ciências Farmacêuticas, Universidade de São Paulo.

FERREIRA, C. L. L. F. Prebióticos e probióticos: atualização e prospecção. Viçosa: Suprema Gráfica e Editora. 2003.

FRANCO, C. M. L. et al. Structural and functional characteristics of selected soft wheat starches. Cereal Chemistry, v. 79, n. 2, p. 243-248, 2002 b. 
FREITAS, T.S.; LEONEL, M. Amido resistente em fécula de mandioca extrusada sob diferentes condições operacionais. Alimentos e Nutrição. Araraquara, v.19, n.2, p.183-190, 2008.

GALLAGHER, J. C. et al. The effect of soy protein isolate on bone metabolism. Menopause, v. 11, n. 3, p. 290-298, 2004.

GARBIERI, V.C.; PACHECO, M.T.B. Revisão: Alimentos funcionais fisiológicos. Brazilian Journal of Food Technology, v.2, n.1,2, p.7-19, 1999.

GARCIA, M. C.; TORRE, M.; MARINA, M. L.; LABORDA, F. Composition and characterization of soybean and related products. CRC Critical Reviews in Food Science and Nutrition, Boca Raton, v.37, n.4, p.361-391, 1997.

GENOVESE, M.I.; LAJOLO, F.M. Isoflavones in soy based foods consumed in Brazil: levels, distribution, and estimated intake. Journal of Agricultural and Food Chemistry, v. 50, p. 5987 - 5993, 2002.

GINSBURG, J.; PRELEVIC; G. M Lack of significant hormonal effects and controlled trials of phyto-oestrogens. The Lancet, New York, n. 355, p. 163-164, 2000.

GOMEZ, M.H.; AGUILERA, J.M. Changes in the starch fraction during extrusion-cooking of corn. Journal of Food Science, v.48, p.378-381, 1983.

GOÑI, I. Food Chemistry.; v 56, n.4, n.2, p.3-16, 1992.

GUJSKA, E.; KHAN, K. Functional properties of extrudates from high starch fractions navy and pinto beans and corn meal blended with legume high protein fractions. Journal of Food Science, v. 56, n. 2, p. 431-435, 1991. 
GUHA, M.; ALI, S. Z.; BHATTACHARYA, S. Effect of barrel temperature and screw speed on rapid viscoanylyzer pasting behavior of rice extruded. International Journal of Food Science and Technology, v. 33, p. 259-266, 1998.

GUTKOSKI, L.C. Extrusão de produtos de aveia. In: GUTKOSKI, L.C.; PEDÓ, I. Aveia: composição química, valor nutricional e processamento. São Paulo: Varela, 2000. cap.7, p.169-103.

HAGENIMANA, A.; DING, X.; FANG, T. Evaluation of rice flour modified by extrusion cooking. Journal of Cereal Science, v. 43, p. 38-46, 2006.

HARPER, J. M. Critical review in food science: nutrition. In: Food extrusion. Colorado: CRC Press, 1979. v. 2, p. 155-211.

HASHIMOTO, J.M.; GROSSMANN, M.V.E. Effects of extrusion conditions on quality of cassava bran/cassava starch extrudates. International Journal of Food Science and Technology, v.38, n.5, p.511-517, 2003.

HAN, K. K. et al. Efeitos dos fitoestrógenos sobre alguns parâmetros clínicos e laboratoriais no climatério. Revista Brasileira de Ginecologia e Obstetrícia, v. 24, n. 8, p. 547-552, set. 2002.

HIBI, H. Y. Effect of lipids on the viscoelastic properties of rice starch gel. Starch/Stärke, New york, v. 46, n. 2, p. 44-48, 1994.

HORAN, F. E. Soy protein products and their production. Journal of the American Oil Chemist's Society, Champaign, v.51, n.1, p.67a-73a, jan. 1974.

HTOON, A.; SHRESTHA, A.K.; FLANAGAN, B.M.; LOPEZ-RUBIO, A.; BIRD, A.R.; GILBERT, E.P.; GUDLEY, M.J. Effects of processing high amylase maize starches under 
controlled conditions on structural organization and amylase digestibility. Cabohydrate Polymers, v.75, p.236-245, 2009.

IAL. INSTITUTO ADOLFO LUTZ. Normas Analíticas do Instituto Adolfo Lutz: Métodos químicos e físicos para análise de alimentos. $3^{\mathrm{a}}$ e. São Paulo, v.1, 1985. 126p.

ILO, S.; BERGHOFER, E. Kinetics of colour changes during extrusion cooking of maize grits. Journal of Food Engineering, Oxford, v. 39, n. 1, p. 73-80, 1999.

JANE, J.; CHEN, Y. Y.; LEE, L. F.; McPHERSON, A. E., WONG,K.S.; RADOSAVLJEVIC, M., KASEMMSUWAM, T. Effects of amylopectin branch chain length and amylase content on the gelatinization and pasting properties of starches. Cereal Chemistry, v. 76, n. 5, p. 629637, 1999.

KARAM, L. B.; GROSSMANN, M. V. E.; SILVA, R. S. S. F. Misturas de farinha de aveia e amido de milho com alto teor de amilopectina para produção de snacks. Ciência e Tecnologia de Alimentos, Campinas, v. 21, n. 2, p. 158-163, 2001.

KIM, H.; PETERSON, T. G.; BARNES, S. Mechanisms of action of the soy isoflavone genistein: emerging role for its effects via transforming growth factor beta signaling pathways. American Journal of Clinical Nutrition, Bethesda, v. 68, n. 6, p.1418S-1425S, Suppl. S, 1998.

LAJOLO, F. Alimentos funcionales en América Latina. Alimentación Latino Americana, n.238, p.22-24, 2001.

LARREA, M. A.; CHANG, Y. K;. MARTÍNEZ-BUSTOS, F. Effects of some operational extrusion parameters on the constituents of orange pulp. Food Chemistry, Oxford: Elsevier, v. 89, nº 2. p. 301-308, Feb. 2005. 
LEBOURG, C. Brasamide et la fécule: une historie d'amour. Botucatu: Centro de Raízes Tropicais, 1996. 59p.

LEMOS, L.B., DURIGAN, J.F., FORNASIERE FILHO, D., PEDROSO, P.A.C., BANZATTO,D.A. Características de cozimento e hidratação de grãos de genótipos de feijão comum (Phaseolus vulgaris L.). Alimentação e Nutrição, São Paulo, v.7, p.47-57, 1996.

LEONEL, M. , CEREDA, M. P, ROAU, X. Aproveitamento do resíduo da produção de etanol a partir de farelo de mandioca, como fonte de fibras dietéticas. Ciência e Tecnologia de Alimentos, v.19, n.2, p.241-245, 1999.

LEONEL, M. Caracterização da fibra e uso do farelo de mandioca como base para produtos dietéticos. In: LEONEL, M. Manejo, uso e tratamento de subprodutos da industrialização da mandioca. São Paulo: Fundação Cargill, Série Culturas de Tuberosas Amiláceas Latino Americanas, 2001. p. $221-226$.

LEONEL, M., CEREDA, M, M. P. Avaliação da concentração de pectinase no processo de hidrólise-sacarificação do farelo de mandioca para a obetenção de etanol. Ciência e Tecnologia de Alimentos, Campinas, v. 20, n. 2 May/Aug. 2000.

LEONEL, M.; CAMARGO, K.F.; MISCHAN, M.M. Produção de biscoitos extrusados de polvilho azedo com fibras: efeito de parâmetros operacionais sobre as propriedades físicas. Ciência e Tecnologia de Alimentos, Campinas, v.28, n.3, p.1-6, 2008.

LEONEL, M.; FREITAS, T. S.; MISCHAN, M. M. Características físicas de amido de mandioca extrusado. Scientia. Agrícola. Brasil, vol.66, n.4, p. 486-493, 2009.

LEORO, M. G. V. Desenvolvimento de cereal matinal extrusado orgânico à base de farinha de milho e farelo de maracujá. 2007. 123 f. Dissertação (Mestrado em Engenharia de Alimentos/Tecnologia de Alimentos)-Faculdade de Engenharia de Alimentos, Universidade Estadual de Campinas, 2007. 
LIRA FILHO, J. F. de. Efeitos da extrusão termoplástica sobre as propriedades tecnológicas e nutritivas das proteínas da farinha integral do feijão caupi (Vigna unguilata (L Walp)). Campinas, 2001. 148 f. Tese (Doutorado em Tecnologia de Alimentos), Faculdade de Engenharia de Alimentos, Universidade Estadual de Campinas.

LUSTOSA, B.H.B., LEONEL, M., LEITE, T.D., FRANCO, C.M.L., MISCHAN, M.M. Produção de farinha instantânea de mandioca: efeito das condições de extrusão sobre as propriedades térmicas e de pasta. Acta Scientiarium Technology, v.31, n.2, p.231-238, 2009.

MAIA, L. H.; WNAG, S. H.; ASCHERI, J. L. R.; CABRAL, L. C.; FERNANDES, M. S. Viscosidade de pasta, absorção de água e índice de solubilidade em água dos mingaus desidratados de arroz e soja. Ciência e Tecnologia de Alimentos. v. 19, n3, 1999.

MARTINS, J. C.; LEONEL, M.; MISCHAN, M. M. Propriedades de pasta de misturas extrusadas de polvilho azedo e farinha de soja integral. In: XIII CONGRESSO BRASILEIRO DE MANDIOCA, Anais: VII WORKSHOP SOBRE TECNOLOGIAS EM AGROINDÚSTRIA DE TUBEROSAS TROPICAIS, Botucatu. Faculdade de Ciências Agronômicas. Botucatu. CERAT/UNESP, v.5, p. 936-940, jul 2009.

MARTINS, V.B.; NETTO, F. M. Physicochemical and functional properties of soy protein isolate as a function of water activity and storage. Food Research International, v.39, p. 145153. 2006.

MÁXIMO, D. A soja na alimentação. In: Soja: uma caminhada sem fim: como a soja conquistou o mundo e o Brasil. [São Paulo]: Fundação Cargill, [199_]. p. 58 - 66.

MENDES, F. J. G. Nutrição. Disponível em: <http:// www. florbelamendes.net.htm>. Acesso em 17 de dezembro de 2009. 
MENDONÇA, S.; GORSSMANN, M. V. E.; VERBÉ, R. Corn bran as a fibre source in expanded snacks. Lebensmittel Wissenschaft and Technologie, Zürich, v. 33, n. 7, p. 2-8, 2000.

MENEGASSI, B., LEONEL, M., MISCHAN, M.M., PINHO, S.M.Z. Efeito de parâmetros de extrusão na cor e propriedades de pasta da farinha de mandioquinha-salsa (Arracacia xanthorrhiza). Ciência e Agrotecnologia, v.31, n.6, p.1780-1792, 2007.

MESA, N.J.E. et al. Soy protein-fortified expanded extrudates. Baseline study using normal corn starch. Journal. Food Engeering, v.90, p.262-270, 2009.

MORIKAWA, K.; NISHINARI, K. Effects of concentration dependence of retrogradation behaviour of dispersions for native and chemically modified potato starch. Food Hydrocolloids, v. 14, p. 395-401, 2000.

NELSON, N. A. Photometric adaptation of the Somogy method for determination of glucose. Journal Biology Chemists., Baltimore, nº 153, p. 375-80, 1944.

NEWPORT SCIENTIFIC. Operation manual for series 4: Instrutions Manual. Warriewood. Austrália, 1998, p. 123.

NUNES, O.L.G.S. Avaliação de parâmetros relacionados à expansão de fécula de mandioca ácido-modificada e irradiada com ultravioleta. Botucatu, 1999, 87p. Tese (Doutorado em Agronomia/ Energia na Agricultura) - Faculdade de Ciências Agronômicas, UNESP.

OKADA, M. Produção e Aplicação de proteína isolada de soja. In: SIMPÓSIO ALIMENTOS FUNCIONAIS PARA O NOVO MILÊNIO QUALIDADE E SAÚDE, 2000, Campinas.

Anais. Faculdade de Engenharia de Alimentos, 24 p. 2000. 
ONWULATA, C.I.; KONSTANCE, R.P.; SMITH, P.W.; HOLSINGER, V.H. Co-extrusion of dietary fiber and milk proteins in expanded corn products. Lebensmmittel-Wissenschaft Und Technologie, v.34, p.424-429, 2001.

OWUSU-ANSAH, J.; VAN De VOORT, F. R.; STANLEY, D. W. Physicochemical changes in cornstarch as a function of extrusion variables. Cereal Chemistry, v. 60, n. 4, p. 319-324, 1983.

PEREIRA, K. D. Amido resistente, a última geração no controle de energia e digestão saudável. Ciência e Tecnologia de Alimentos. Campinas, v.27, suppl. 1, Aug. 2007.

POTTER, S. M. et al. Soy protein and isoflavones: their effects on blood lipids and bone density in postmenopausal women. American Journal of Clinical Nutrition, Bethesda, v. 68, n. 6, p. 1375S-1379S, Suppl. S, 1998.

PUPPO, M. C.; AÑÓN, M. C. Soybean protein dispersions at acid pH. Thermal and rheological properties. Journal of Food Science, Chicago, v. 64, n. 1, p. 50-56, 1999.

RAUPP, D. S. et al.; Arraste via fecal de nutrientes da ingestão produzido por bagaço de mandioca hidrolisado. Scientia Agricola. Piracicaba. v. 59. n 2, p. 1-14, Piracicaba, 2002.

RICKARD, J. E.; ASAOKA, M.; BLANSHARD, J. M. V. The physicochemical properties of cassava starch. Tropical Science, v. 31, p. 189-207, 1991.

SAITO, I. M. Produção de hidrolisado e fibras a partir de resíduo da industrialização da mandioca submetido à pré-tratamento hidrotérmico. 2005. 97 f. Tese (Doutorado em Agronomia/Energia na Agricultura)-Faculdade de Ciências Agronômicas, Universidade Estadual de Botucatu, 2005.

SANTOS, A. P. S. F. Efeito da substituição da proteína do farelo de soja pela proteína do farelo de algodão sobre o desempenho e avaliação de carcaça em frangos de corte. 
Pernambuco, 2006. 57 p. Dissertação (Mestrado em Zootecnia ) - Universidade Federal Rural de Pernambuco.

SEBIO, L. Efeito de alguns parâmetros operacionais de extrusão nas propriedades físicoquímicas da farinha de inhame (Dioscorea rotundata). Campinas, 1996. 106p. Dissertação (Mestrado em Tecnologia de Alimentos) - Faculdade de Engenharia de Alimentos, Universidade Estadual de Campinas.

SIILVA, M. S. et al.; Composição química e valor protéico do resíduo de soja em relação ao grão de soja. Campinas, v. 26, n. 3, p. 572, 2006.

SILVEIRA, E. T. F.; TRAVAGLINI, D. A.; VITTI, P.; CAMPOS, S. D. S.; AGUIRRE, J. M.; FIGUEIREDO, I. B.; SHIROSE, I. Farinha composta de resíduo do extrato de soja e de arroz em mistura com trigo para uso em panificação. Boletim do Instituto de Tecnologia de Alimentos, Campinas, v. 18, n. 4, p. 543-561, 1981.

SIMONETTI. M. O grão milagroso. In: Soja: uma caminhada sem fim: como a soja conquistou o mundo e o Brasil. [São Paulo]: Fundação Cargill, [199-]. p. 34 - 36.

SOMOGY, M. Determination of blood sugar. Journal Biology Chemisty. n.160, p. 69-73, 1945.

SOUZA, L.B.; LEONEL, M.; MISCHAN, M.; M. Efeito dos parâmetros de extrusão nas propriedades físicas de extrusados de misturas de fécula de mandioca e polpa cítrica. Alimentos e Nutrição. Araraquara, v.18, p.83-91, 2007.

SGARBIERI, V. C. Proteínas em alimentos protéicos: propriedades, degradações, modificações. Editora Varela, 1996, São Paulo, p. 259-335, 357p.

SGARBIERI, V. C.; PACHECO, M. T. B. — Revisão : alimentos funcionais fisiológicos. Brazilian Journal of Food Technology, v. 2, p. 7-19, 1999. 
SMITH, O. B. Why extrusion cooking? Cereal foods world, v. 21, n.1, p. 4-7, 1976.

THAKUR, S.; SAXENA, D.C. Formulation of extruded snack food (gum based cereal-pulse blend): optimization of ingredients levels using response surface methodology. LebensmWiss. U-Technology., 2000. v.33, p.354-361.

THEBAUDIN, J.Y.; LEFEBRE, A.C.; HARRINGTON, M.; BOURGEOIS, C. M. Dietary fibres: Nutritional and technological interest. Trends in Food Science \& Technology, v.8, p.41-48, 1997

TEIXEIRA, C. G. A soja na alimentação humana. Disponível em:<http://www.vegetarianismo.com.br/soja1.html>. Acesso em: 15 Jan. 2004.

TESTER, R. F. Starch: The polysaccharide fractions. Cambridge. The Royal Society of Chemistry, p. 43-50, 1997.

TOPPING, D. L. CLIFTON, P. M. Short-chain fatty acids and human colonic function: roles of resistant starch and non starch polysaccharides. Physiological Reviews, v. 81, n. 3, p. 10311064, 2001.

THOMAS, D. J., ATWELL, W. A. Starches: Practical Guides for the Food Industry. Minnesota: Eagan Press, 1999. 94 p.

VELÁSQUEZ, O.C.; LEDERER, H.M.; ROMBEAU, J.L. Butyrate and colocyte. Implications for neoplasia. Digestive Diseases Sciences, v.41, p.727-39, 1996.

VILPOUX, O. F. A cadeia de mandioca no Brasil. Campo Grande: SEBRAE-MS, 82 p. 2006. 
WHISTLER, R. L.; BeMILLER, J. N. Starch. In: WHISTLER, R. L.; BeMILLER, J. N.

Carbohydrate Chemistry for Food Scientists. AACC. St Paul: Eagan Press, 1997. p. 117151.

YACU, W. Process instrumentation and control in food extruders. Cereal Foods World, n.35, n.9, p.919-926, 1990.

YU, L.; CHRISTIE, G. Measurement of starch thermal transitions using differential scanning calorimetry. Carbohydrate Polymers, v. 46, n. 2, p. 179-184, 2001. 